\title{
The Current Account and Macroeconomic Adjustment in the 1970s
}

DURING THE PAST DECADE, the behavior of international capital flows, current account balances, and exchange rates have puzzled economists and preoccupied policymakers. The period has been marked by widely fluctuating exchange rates, huge OPEC surpluses, burgeoning debt of less developed countries (LDCs) and unprecedented current account deficits in many developed countries. The nature, direction, and scope of international borrowing have also shifted dramatically. The proportion of private to official capital inflows to LDCs has grown substantially; the international money market has expanded dramatically; and capital controls have been liberalized in many economies.

The need for analysis is greatest on two sets of questions. First, what factors have determined the size and direction of current account imbalances in recent years? Second, what has been the relation between the current account and movements in the exchange rate? Answers to the first question have tended to focus on OPEC price increases and surpluses. Observing that the large surpluses must be balanced in the aggre-

This paper is part of a research project on the effects of OPEC price increases on macroeconomic adjustment in the world economy, in collaboration with Michael Bruno of Hebrew University, Jerusalem. I have benefited from discussions with Olivier J. Blanchard, Michael Bruno, Barry J. Eichengreen, Paul Krugman, and Robert Macauley, and from comments by the Brookings panel. I am indebted to Wing Woo for research assistance and to Joy Mundy for secretarial help. 
gate by the deficits of oil-importing countries, many analysts have attributed the current account difficulties of individual countries to their oil imports and have regarded reduction of those imports as a major policy objective. For example, in discussing the worsening U.S. current account deficit in 1977, Paul Volcker, chairman of the Federal Reserve, stressed: "Oil imports have increased by nearly $\$ 20$ billion in the past two years alone, directly accounting for about half of the reversal in our trade from a surplus of $\$ 9$ billion to a deficit of $\$ 30$ billion. . . . Given the burden of the oil imports on our external payments, to maintain that confidence [in our financial policy] it is particularly important that we can point to the prospect over time, not of inexorable increases in our oil imports but of a decline." 1

McKinnon has taken a different view: "rationalization of American energy policy would probably reduce imports of fossil fuels into the United States, but would be offset elsewhere as long as America is deficient in saving [or booming in investment]. The microeconomic details of trade in this or that commodity are dominated by broad investmentsavings considerations - unlike current heated political discussions of these issues would suggest.",2 One aim of this paper is to evaluate these contrasting positions. Although there is some evidence of links between current account deficits and oil import dependence in cross-country data, these connections tend to hold only in the short run, and they disappear a few years after the 1973 oil price increase. Moreover, differences in investment activity among countries are found to be at least as important as oil dependence in explaining current account experiences since 1973. McKinnon's position is vindicated as a proposition describing events over a period of several years.

On the second question, at a theoretical level almost any combination of deficits or surpluses, appreciation or depreciation, is possible, depend-

1. Paul A. Volcker, "The Challenges of International Economic Policy," Quarterly Review of the Federal Reserve Bank of New York, vol. 2 (Winter 1977-78), pp. 3-4. As Stanley Fischer points out in his discussion of this paper, Volcker indicates that oil dependence does not provide a complete explanation of recent current account movements and cites the example of Japan in support of his argument.

2. Ronald I. McKinnon, "Exchange-Rate Instability, Trade Imbalances, and Monetary Policies in Japan and the United States," in Peter Oppenheimer, ed., Issues in International Economics (Stocksfield, England: Orill Press Ltd., 1980), p. 237. This excellent study focuses on the United States and Japan, but does not consider the issue of oil imports directly nor the current account patterns of other countries. 
ing on the underlying exogenous disturbances affecting the economic system. Only when a specific set of factors can be identified as a dominant influence on the current account can a determinate relation be predicted between deficits and the exchange rate.

This paper focuses on the determinants of current account balances and exchange rates in the intermediate run. With this horizon in mind, the analysis assumes that output levels are supply-determined and not affected by aggregate demand; real interest rates are tied to the marginal productivity of capital and are not influenced by monetary policies, and frictions in adjusting to shocks are unimportant. These presumptions still permit a variety of responses, depending on the nature of shocks to the system and whether they are perceived as temporary or permanent. Departures of the economy from its supply-constrained path-caused by demand variations or slow adjustment to shocks - are not part of the main analysis, although they are considered as amendments to the model and are allowed for in some of the empirical tests.

The paper emphasizes the importance of fixed investment to macroeconomic performance. It shows theoretically how a rise in investment enlarges the current account deficit and raises the real exchange rate. And it presents empirical evidence that variations in investment demand have dominated the medium-run behavior of current accounts and exchange rates in the 1970 s.

\section{Overview of the Current Account in the 1970s}

Tables 1 through 5 indicate the huge changes in world trade and current account flows in the 1970s. The tables illustrate the size of overall current account imbalances for various regions, the magnitudes of these imbalances relative to gross national products, and the role of oil imports in the global shifts of the current account. Table 1 presents both conventional and adjusted measures of the current account. The adjusted measures correct for distortions in the accounts caused by inflation. The current account measures the net trade of goods and services plus transfers plus the net investment income from abroad. When the foreign investment is in nonindexed interest-bearing assets such as bank loans or bonds, inflation distorts the measurement of the investment income. The conventional current account records the interest payments received by 


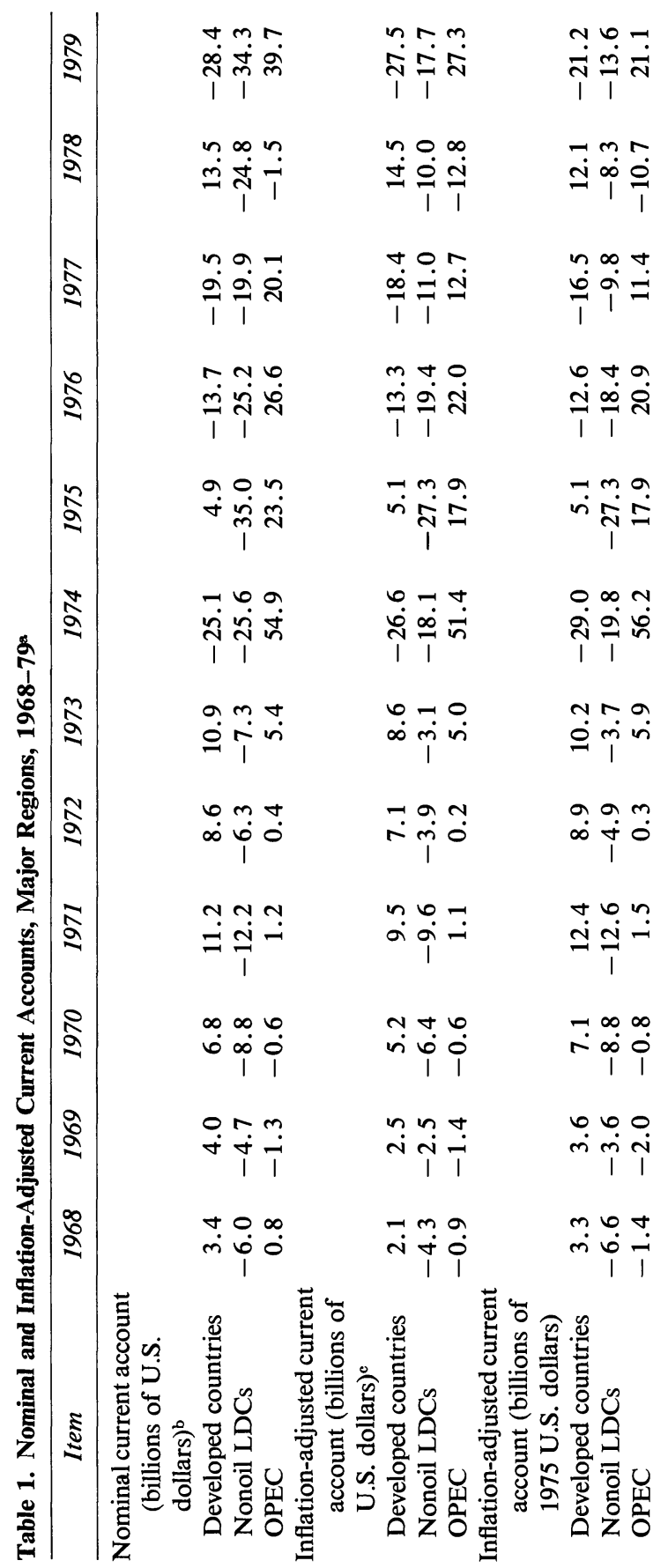




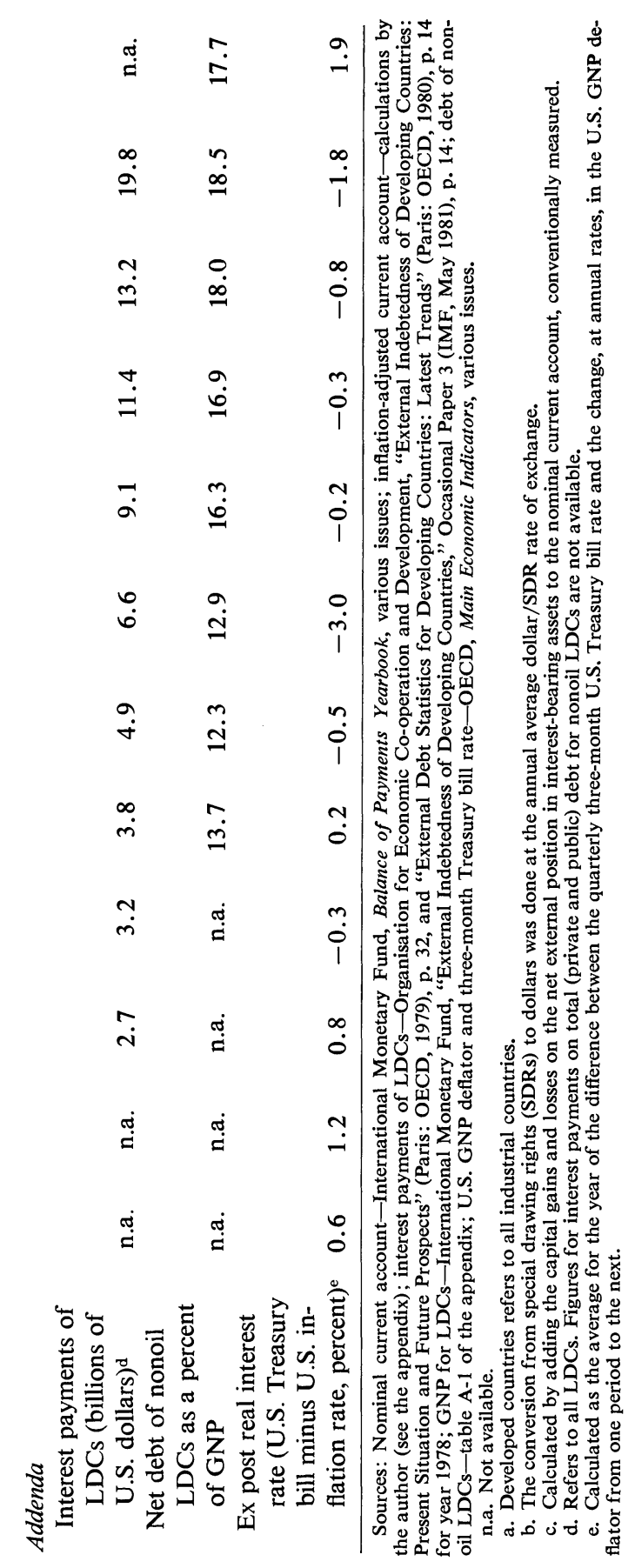


Table 2. Bilateral Trade Flows between Major Regions, 1972-77a

Billions of U.S. dollars

\begin{tabular}{|c|c|c|c|c|c|c|}
\hline Flows by region & 1972 & 1973 & 1974 & 1975 & 1976 & 1977 \\
\hline \multicolumn{7}{|l|}{ Developed countries } \\
\hline \multicolumn{7}{|l|}{ Exports to } \\
\hline Nonoil LDCs & 41.8 & 57.5 & 84.8 & 90.9 & 92.4 & 105.2 \\
\hline OPEC & 11.7 & 16.3 & 29.0 & 47.5 & 54.8 & 67.7 \\
\hline \multicolumn{7}{|l|}{ Trade balance with } \\
\hline Nonoil LDCs & 9.2 & 10.3 & 16.9 & 26.7 & 11.5 & 12.9 \\
\hline OPEC & -11.5 & -18.0 & -67.8 & -36.4 & -46.7 & -45.1 \\
\hline \multicolumn{7}{|l|}{ Nonoil LDCs } \\
\hline \multicolumn{7}{|l|}{ Exports to } \\
\hline Developed countries & 32.6 & 47.1 & 67.8 & 64.1 & 80.9 & 92.3 \\
\hline OPEC & 1.4 & 2.4 & 4.7 & 5.8 & 6.5 & 9.0 \\
\hline \multicolumn{7}{|l|}{ Trade balance with } \\
\hline Developed countries & -9.2 & -10.3 & -16.9 & -26.7 & -11.5 & -12.9 \\
\hline OPEC & -3.7 & -4.6 & -19.3 & -17.7 & -21.5 & -22.2 \\
\hline \multicolumn{7}{|l|}{ OPEC } \\
\hline \multicolumn{7}{|l|}{ Exports to } \\
\hline Developed countries & 23.2 & 34.3 & 96.8 & 83.8 & 101.5 & 112.7 \\
\hline Nonoil LDCs & 5.1 & 6.9 & 24.0 & 23.5 & 28.1 & 31.2 \\
\hline \multicolumn{7}{|l|}{ Trade balance with } \\
\hline Developed countries & 11.5 & 18.0 & 67.8 & 36.4 & 46.7 & 45.1 \\
\hline Nonoil LDCs & 3.7 & 4.6 & 19.3 & 17.7 & 21.5 & 22.2 \\
\hline
\end{tabular}

creditors but not the real capital losses (or the capital gains of debtors) due to inflation. A rise in inflation that is exactly matched by a rise in interest rates causes a rise in interest income for a creditor country that is exactly offset by greater capital losses. Since only the increased interest income is recorded in the current account, the measured current account surplus rises. Conversely, debtor countries show a lower current account balance under inflationary conditions than they would with stable prices because the accounts do not show their real gain on outstanding debt.

In table 1 the real capital gains and losses on outstanding interestbearing assets have been added to the conventionally measured current account for each region. The adjustments are important because interest payments of the LDCs constitute a large part of their current account deficits, as shown in the addenda at the bottom of table 1 . Similar calcu- 
Table 3. Oil Imports and the Current Account as a Percentage of Gross National Product, Developed Countries, Selected Periods, 1968-79

\begin{tabular}{|c|c|c|c|c|c|c|}
\hline \multirow[b]{2}{*}{ Country ${ }^{\mathrm{a}}$} & \multicolumn{2}{|c|}{$\begin{array}{c}\text { Oil imports as a } \\
\text { percent of GNP } \\
\left(M^{o i l} / G N P\right)\end{array}$} & \multicolumn{2}{|c|}{$\begin{array}{c}\text { Current account as a } \\
\text { percent of GNP } \\
(C A / G N P)\end{array}$} & \multirow{2}{*}{$\begin{array}{c}\Delta(C A / G N P) \\
\text { (percentage } \\
\text { points) }\end{array}$} & \multirow{2}{*}{$\begin{array}{c}\text { Conntry } \\
\text { rank by } \\
\Delta(C A / G N P)\end{array}$} \\
\hline & $1968-73$ & $1974-79$ & $1968-73$ & $1974-79$ & & \\
\hline Finland & 2.8 & 5.5 & -1.2 & -2.7 & -1.5 & 9 \\
\hline Belgium & 2.5 & 4.2 & 2.5 & -0.4 & -2.9 & 3 \\
\hline Denmark & 2.4 & 4.3 & -2.1 & -3.3 & -1.2 & 10 \\
\hline Sweden & 2.0 & 4.2 & 0.3 & -1.6 & -1.9 & 5 \\
\hline Japan & 1.9 & 4.6 & 1.3 & 0.3 & -1.0 & $6-8$ \\
\hline Norway & 1.9 & -1.4 & -1.0 & -8.0 & -7.0 & 1 \\
\hline United Kingdom & 1.7 & 2.6 & 0.4 & -1.2 & -1.6 & $6-8$ \\
\hline Italy & 1.6 & 4.4 & 1.4 & -0.2 & -1.6 & $6-8$ \\
\hline France & 1.4 & 3.4 & -0.3 & -0.6 & -0.9 & 11 \\
\hline Austria & 1.4 & 2.9 & 2.5 & -0.4 & -2.9 & 2 \\
\hline Germany & 1.0 & 2.7 & 1.0 & 1.0 & 0.0 & $13-14$ \\
\hline Netherlands & 0.8 & 0.6 & 0.9 & 1.1 & 0.2 & 15 \\
\hline United States & 0.2 & 1.8 & 0.0 & 0.0 & 0.0 & $13-14$ \\
\hline Australia & 0.0 & -0.4 & -1.7 & -2.3 & -0.6 & 12 \\
\hline Canada & -0.3 & -0.8 & 0.0 & -2.0 & -2.0 & 4 \\
\hline
\end{tabular}

Sources: Net oil imports-Organisation for Economic Co-operation and Development, Foreign Trade Statistics, Series A, various issues; current account-OECD, Main Economic Indicators, various issues GNP-OECD, National Accounts of OECD Countries, 1950-78 (Paris: OECD, 1980), vol. 1 and recent supplements.

a. Countries are arranged by rank of oil dependence in 1968-73.

lations are made for four developed economies in the appendix. These calculations show that the U.S. current account deficits in recent years have been overstated by about $\$ 1$ billion because of the inflation bias.

The patterns in the current accounts displayed in tables 1 through 5 can be roughly summarized. In the early 1970s the nonoil LDCs had modest current account deficits that were approximately matched by surpluses of developed countries; OPEC's small deficits before 1970 became small surpluses during 1970-72. (The sum of the current account deficits of OPEC, the developed countries, and the LCDs is not zero because of the exclusion of some groups of countries such as the members of Comecon, errors and omissions, and asymmetries among nations in balance-of-payments accounting techniques and timing.) The 1973-74 rise in oil prices contributed to an enormous OPEC surplus matched by unprecedented deficits in the developed countries and larger deficits in the LDCs. During the $1975-78$ period the OPEC surplus was reduced as 
Table 4. Current Account as a Percentage of Gross Domestic Product, Nonoil LDCs, 1973-79

\begin{tabular}{llllllll}
\hline \multicolumn{1}{c}{ Category } & 1973 & 1974 & 1975 & 1976 & 1977 & 1978 & 1979 \\
\hline $\begin{array}{l}\text { Net oil-importing } \\
\text { countries }\end{array}$ & -1.9 & -5.4 & -5.7 & -3.7 & -2.8 & -3.1 & -4.0 \\
$\begin{array}{l}\text { Net oil-exporting } \\
\quad \text { countries }\end{array}$ & & & & & & & \\
All nonoil LDCs & -2.9 & -4.4 & -7.1 & -4.9 & -4.4 & -4.2 & -3.3 \\
\hline
\end{tabular}

Source: IMF Annual Report, 1980, table 9, p. 30.

a. Bahrain, Bolivia, the Congo, Ecuador, Egypt, Gabon, Malaysia, Mexico, Peru, the Syrian Arab Republic, Trinidad, Tobago, and Tunisia.

exports to OPEC expanded considerably. During this period the adjustment for inflation is crucial; by 1978 over half of the apparent LDC deficit is attributable to the inflation bias. In that year the published OPEC current account showed approximate balance but in fact indicates a significant deficit when adjusted for the capital losses on OPEC financial claims relative to the rest of the world. In 1979 and 1980 the second oil shock occurred, and OPEC surpluses again rose sharply. Data limitations prevent the calculation of ratios of the current account to income in 1980 for the developed countries and the nonoil LDCs.

There is a dramatic difference between the current account experience of LDCs and developed countries during 1974-77, even though their oilimport dependence is comparable. The ratio of the current account deficit to GNP rose much more for the LDCs than for developed countries (see table 5). In 1978 both groups appear to have returned to the ratios that prevailed before the oil shocks once the inflation adjustments are made. The large LDC deficits resulted in a significant jump in the net debt of the LDCs-defined as gross debt minus foreign exchange reserves - as a percentage of the gross national products of the LDCs, shown in the next to last row of table 1. Again in 1979 and 1980, enormous current account deficits resulted in a sharp rise in the debts of LDCs. The ratio of LDC debt to income leveled off in 1979, but undoubtedly rose again in 1980 .

An important question addressed in tables 3 to 5 is to what extent the relative dependence on oil imports explains movements in the current account for the LDCs and the developed countries. The conventional view holds that deficits increase most in economies that are heavily dependent 


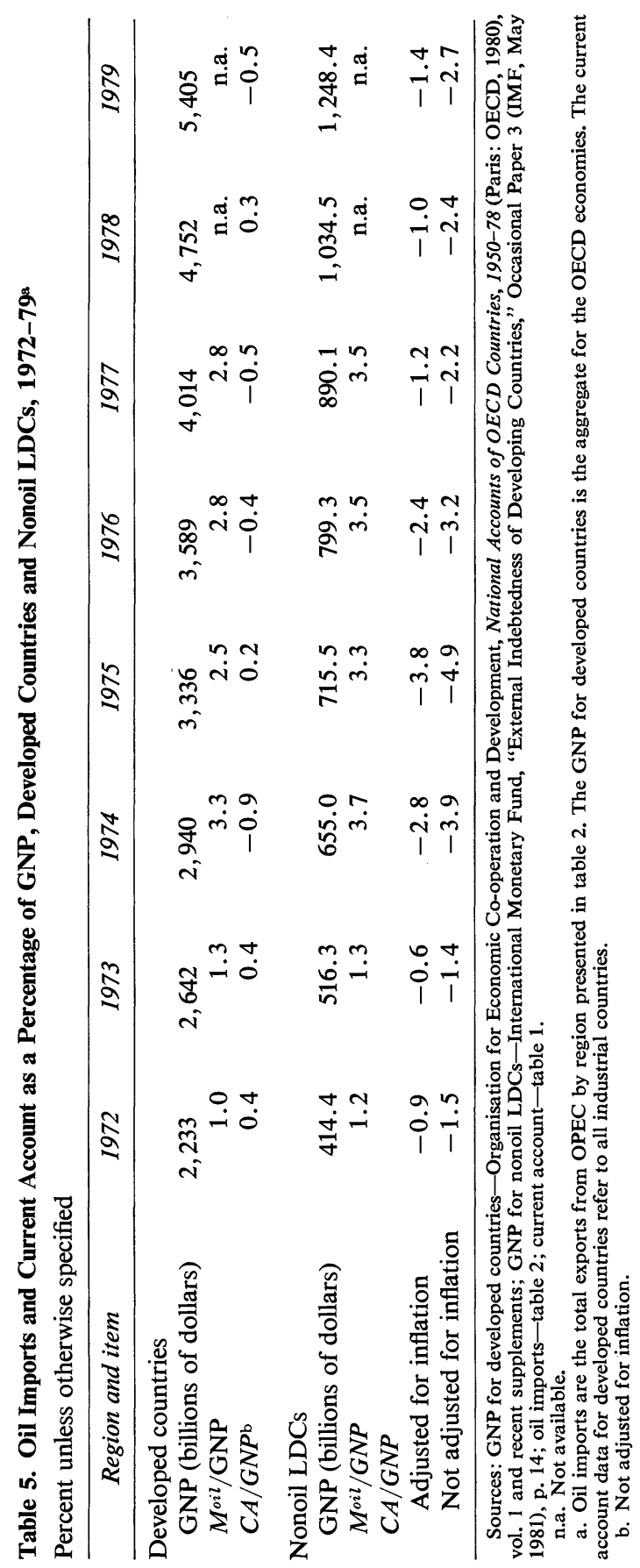


on oil imports and least in the self-sufficient economies. The analysis below suggests a different outcome if the oil price increase is perceived as permanent. In that case, differential dependence on oil imports will have little effect on the relative current account position. If the shock is perceived as temporary, however, the conventional view is correct. Market expectations of the permanence of an oil shock cannot be reconstructed, and no doubt initially there was certainly a wide dispersion of expectations. It is assumed that by 1975 the predominant expectation was that the higher relative price would be maintained, and that this expectation prevailed until the second big price increase that followed the Iranian revolution. These assumptions correspond to what actually happened to prices. $^{3}$

The data in tables 3 and 4 do not suggest a simple correlation between oil dependence and current account deficits. Among the nonoil LDCs the deficit-to-GNP ratio for net oil exporters rose by more in the years between 1973 and 1978 than the ratio for net oil importers! (Unlike other measures of the current account in this paper, table 4 excludes official transfers.) The correlation between high deficits and large oil imports holds only for the years of major price rises (1974 and 1979). Quite similar results are evident for the developed economies. A strong negative relation between the ratio of current account to GNP after 1973, CA/GNP, and the ratio of oil imports to GNP, $M^{o i l} / G N P$, does not hold because the largest oil exporters, Norway and Canada, have the first and fourth largest declines in $C A / G N P$, respectively, after 1973. One can exclude the net oil exporters (defined as countries with net oil exports in some year during the 1968-79 period, including Australia, Canada, Norway, and the United Kingdom, the last of which is self-sufficient), and as conventionally expected, the change in the current account, measured as $\left[(C A / G N P)_{74-79}-(C A / G N P)_{68-73}\right]$, is negatively correlated to the pre1973 ratio, $M^{\text {oil }} / G N P$, with $r=-0.70$. However, this relation seems to derive from the years just after the oil price increase. The correlation of $\left[(C A / G N P)_{76-78}-(C A / G N P)_{68-73}\right]$ with pre-1973 oil dependence,

3. The real price of Saudi petroleum exports in terms of export prices of the industrial countries almost tripled between 1973 and 1974, stayed at the higher plateau in 1974-78, and then jumped again. See International Monetary Fund, International Financial Statistics, various issues, series $76 \mathrm{aad}$ for Saudi Arabia and $74 \mathrm{~d}$ for all industrial countries. 
$\left(M^{o i l} / G N P\right)_{68-73}$, is -0.26 , and the correlation with ex post oil dependence, $\left(M^{o i l} / G N P\right)_{76-78}$, is only -0.085 .

The large deficits of the oil exporters provide the most graphic illustration of a major theme developed below-in a world of capital mobility, shifts in investment opportunities lead to corresponding shifts in the current account. Higher oil prices may have forced countries to run deficits and borrow from abroad (incurring current account deficits) because of the short-run difficulty of adjusting consumption to lower income, but deficits also reflect borrowing to exploit new investment opportunities such as development of indigenous energy supplies.

If one accepts this analysis, two features must be explained concerning the direction and size of current account flows: the sharp increase in the LDC deficits (and corresponding debt) in the 1970s, which cannot be attributed simply to heavy oil import dependence, and the distribution of deficits within the groups of LDCs and developed countries.

Analysis of these issues will help illuminate the relation between deficits and the exchange rate. Below I examine how strong the overall link has been between the current account and the exchange rate in the period of floating exchange rates. I also present empirical evidence for the mechanism suggested by several analysts who have stressed shocks to the real exchange rates as an important source of nominal exchange rate fluctuations. ${ }^{4}$ According to this view, the current account balance and exchange rate can move together if both are related to shocks to the equilibrium real exchange rate. Since I will argue that one important type of real shock has been shifts in expectations about the returns to investment, I describe how the resulting shifts in investment may contribute to changes in the nominal and real exchange rates and show how they may provide a link between the current account and the real exchange rate.

The paper is divided into three parts: the theoretical background for

4. See Michael Mussa, "The Role of the Current Account in Exchange Rate Dynamics" (University of Chicago, June 1980); Alan C. Stockman, "A Theory of Exchange Rate Determination," Journal of Political Economy, vol. 88 (August 1980), pp. 673-98, and "Exchange Rates, Relative Prices, and Resource Allocation," in J. Bhandari and B. Putnam, eds., The International Transmission of Economic Disturbances under Flexible Exchange Rates (MIT Press, forthcoming); and Peter Hooper and John Morton, "Fluctuations in the Dollar: A Model of Nominal and Real Exchange Rate Determination," International Finance Discussion Paper 168 (Board of Governors of the Federal Reserve System, October 1980). 
discussing the fluctuations in current accounts and the real exchange rate, a detailed empirical analysis of current account and capital flows in the 1970s for a cross section of countries, and an analysis of movements of exchange rates in recent years, particularly the U.S. rate.

\section{The Theory of the Current Account}

Current account movements are best analyzed in a dynamic macroeconomic model. This is because current account surpluses or deficits represent national savings or borrowing vis-à-vis the rest of the world and therefore are the outcome of intertemporal choices of households, firms, and governments. ${ }^{5}$ A one-period theory of the current account that describes a static balance of imports and exports makes as much sense as a one-period theory of saving or investment. Because current account imbalances reflect intertemporal choices, expectations of future events can be a decisive factor in determining the size of deficits and surpluses, and these expectations play an important role in the theory below.

In two recent studies I have developed a two-country, multiperiod, growth model that provides a theoretical framework for analyzing the current account. The model assumes perfect foresight, optimal behavior by agents, and perfect international capital mobility. ${ }^{6}$ Although the model abstracts from many features of reality-for example, by assuming full employment-it provides a point of departure for understanding the real world. In this section, I present a simplified two-period version that highlights the central lessons of the general model. It helps in under-

5. Most macroeconomic models of the current account give little attention to intertemporal considerations, though one important area where intertemporal aspects have long been emphasized is the trade and development literature. See, for example, Michael Bruno, "The Two-Sector Open Economy and the Real Exchange Rate," American Economic Review, vol. 66 (September 1976), pp. 566-77; and Michael J. Bazdarich, "Optimal Growth and Stages in the Balance of Payments," Journal of International Economics, vol. 8 (August 1978), pp. 425-43.

6. Jeffrey Sachs, "Energy and Growth under Flexible Exchange Rates: A Simulation Study," Working Paper 582 (National Bureau of Economic Research, November 1980), forthcoming in Bhandari and Putnam, eds., The International Transmission of Economic Disturbances; and David Lipton and Jeffrey Sachs, "Accumulation and Growth in a Two-Country Model: A Simulation Approach," Working Paper 572 (National Bureau of Economic Research, October 1980). 
standing the role of OPEC, government policy, and capital controls in determining current account movements. I also discuss how changing various assumptions of the model alters key results.

To set the stage, I begin with some accounting identities. The current account surplus can be expressed as national income minus national absorption, as the export of goods and services minus their import plus income transfers, or as national saving minus domestic investment. Let $Y$ be gross national product, $Q$ be gross domestic product, and $F$ be net factor payments from abroad such as remittances or interest on foreign bonds. All variables are expressed in units of the good produced in the home country. By definition,

$$
Y=Q+F
$$

GNP plus net unilateral transfers from abroad, $R$, may be used for consumption, $C$, gross private saving, $S^{P}$, and taxes, $T$ :

$$
Y+R=C+S^{P}+T \text {. }
$$

Government saving, $S^{a}$, is given by $T-G$, where $G$ is government consumption of goods and services. Output market equilibrium requires

$$
Q=C+I+G+X-M \text {. }
$$

If the current account surplus, $C A$, is defined as the net export of goods and services plus unilateral transfers and net factor payments from abroad, equations 1 through 3 provide three equivalent definitions:

$$
\begin{aligned}
C A & =X-M+F+R \\
& =Y-(C+I+G)+R \\
& =\left(S^{P}+S^{G}\right)-I .
\end{aligned}
$$

The first equality is the standard definition. The second reflects Sidney Alexander's insight that the surplus must also equal income minus absorption $(C+I+G)$. The third equality represents $C A$ as the excess of saving over investment. When rewritten as $C A+I=S^{P}+S^{G}$, the expression shows that national saving must equal national investment, which is the sum of domestic $I$ and foreign $C A$ components.

The shortcoming of an approach that focuses on a one-period determi- 
nation of the current account is apparent from the absorption form of $C A$ in equation 4. Modern theories of saving and investment emphasize that the responses of $C$ and $I$ to various disturbances depend crucially on expectations of how current shocks affect key future economic variables. ${ }^{7}$ Thus the response of $C$ to an exogenous drop in $Y$ is crucially affected by how permanent the $Y$ shift is expected to be (assuming that real interest rates are constant). A temporary drop in $Y$ will not be matched by an equal fall in $C$, while a permanent drop in $Y$ will. Similarly, investment should move little if the dip in $Y$ is temporary, but should fall if the slump is expected to be permanent. Clearly $C A=Y-C-I-G$ tends to worsen in the first case, but not in the second.

Thus, to forecast the magnitude of the effects of a disturbance on the current account, one must ask whether that disturbance is temporary or permanent, unanticipated or anticipated. The conventional approach of forecasting current account movements based on export and import demand equations, appears to avoid this complexity, but actually does not. A correctly specified import demand equation shows $M$ as a function of spending on $C, I$, and $G$, and of the relative prices of home and foreign goods. It is necessary therefore to forecast $C, I$, and $G$, to find $M$ and hence the intertemporal saving and investment decisions of households, firms, and government.

Increases in oil prices that permanently reduce $Y$ will, after a period of adjustment, reduce $C$ by about an equal amount. Countries that are heavily dependent on oil imports experience large drops in $Y$ and $C$ as a result of a permanent oil price increase; oil self-sufficient economies, on the other hand, will have little change in these variables. Oil dependence determines the extent of the real income loss brought about by OPEC, but not the extent of current account deficits since both income and consumption are affected. Temporary price increases have a different result. Countries heavily dependent on oil have a transitory fall in $Y$ that will be unmatched by a fall in $C$. These countries will find it worthwhile to borrow temporarily in order to smooth consumption over time; because transitory in-

7. For a study on savings see, for example, Alan S. Blinder, "Temporary Income Taxes and Consumer Spending," Journal of Political Economy, vol. 89 (February 1981), pp. 26-53; on investment see, among other studies, Olivier Jean Blanchard, "Demand Disturbances and Output," Discussion Paper 777 (Harvard Institute of Economic Research, July 1980). 
come changes should have small effects on $C$, a temporary price shock should lead to larger deficits in oil-dependent countries.

\section{A Two-Period Model of the Current Account}

The formal two-period model of the current account developed here places great emphasis on the optimal behavior of firms and households, and pays explicit attention to the nature of disturbances to the economy. The model is based upon life-cycle saving, perfect capital mobility, and a value-maximizing investment strategy of firms. Output is supply-determined as a function of the capital stock and the real prices of factors of production. These assumptions make the model most appropriate for explaining the current account in the intermediate run, over which aggregate demand effects on output may be ignored.

Consider a small, open economy that produces a single good at a fixed world price of 1 . Suppose the economy has a zero initial foreign investment position and a first-period capital stock, $K_{1}$. The real interest rate at which domestic households can borrow and lend from the rest of the world is fixed at $r^{*}$. Production in each of the two periods is characterized by constant returns to scale and given by

$$
Q_{i}=\theta_{i} F\left(K_{i}, L_{i}, N_{i}\right) \quad i=1,2,
$$

where $N$ is an intermediate input, say oil. The domestic economy produces $N^{H}$ units and imports the remainder from the world market at price $P_{N}$, the real price of oil relative to final output. The $\theta$ is an efficiency parameter that may change between periods. As an example, assume that labor is always fully employed at $L=\bar{L}$. Second-period capital, $K_{2}$, equals $K_{1}+I$.

The optimal production and investment decisions in this economy are straightforward. Firms maximize the value of the firm, which is equivalent to maximizing the discounted value of dividends. Clearly $I_{1}$ is selected so that

$$
\frac{\partial Q_{2}}{\partial K_{2}}=(1+r)
$$

and in each period $\partial Q / \partial N=P_{N}$ and $\partial Q / \partial L=w$. Here $r$ is the home in- 
terest rate, always equal to $r^{*}$ by the assumption of perfect capital mobility. The condition in equation 6 defines an investment schedule of the form

$$
\begin{gathered}
I=K_{2}\left(r^{*}, \theta_{2}, P_{N_{2}}\right)-K_{1} \\
\frac{\partial K_{2}}{\partial r^{*}}<0, \frac{\partial K_{2}}{\partial \theta_{2}}>0, \frac{\partial K_{2}}{\partial P_{N 2}} \gtrless 0 .
\end{gathered}
$$

The sign of $\partial K_{2} / \partial P_{N_{2}}$ depends on $\partial^{2} F / \partial K \partial N$ in the production function. As long as the cross-partial derivative is positive, the "standard case," $\partial K_{2} / \partial P_{N_{2}}$, is negative. ${ }^{8}$ In the first and second periods the wage, $w$, adjusts so that $\partial Q / \partial L_{i}=w_{i}$ at full employment. Depending on the production function, $\partial w_{1} / \partial P_{N_{1}} \gtrless 0$, while $\partial w_{2} / \partial P_{N_{2}}$ is less than zero necessarily. ${ }^{9}$

Households maximize a two-period utility function $U\left(C_{1}, C_{2}\right)$ subject to an intertemporal budget constraint. The discounted value of household consumption, $C_{1}+C_{2} /(1+r)$, must equal household wealth, $W$, which is the sum of human wealth, $H$, the market value of domestic firms, $V$, and the value of domestic production of $N$, which $N^{v}$ denotes. Thus,

$$
C_{1}+\frac{C_{2}}{1+r}=W=H+V+N^{v} .
$$

Human wealth, $H$, is the discounted value of labor income net of labor taxes,

$$
H=w_{1} L_{1}-T_{1}+\frac{w_{2} L_{2}-T_{2}}{1+r} .
$$

8. It can be easily shown that $\partial K_{2} / \partial P_{N_{2}}$ equals $F_{K N} /\left[\theta_{2}\left(F_{K N}^{2}-F_{N N} F_{K K}\right)\right]$, which has the same sign as $F_{K N}$. If production is constant elasticity of substitution, $C E S$, among $K, L$, and $N$, the $F_{K N}$ is necessarily greater than zero. (Cobb-Douglas is a special case.) Also, with a two-level $C E S$ technology in $V(K, L)$ and $N$, the $F_{K N}$ is again positive. One case in which $F_{K N}$ is less than zero is given by $Q_{2}=\theta_{2} F[G(K, N), L]$, where the function $G$ is $C E S$ with elasticity $\sigma ; F(G, L)$ is $C E S$ with elasticity $\sigma_{1}$; and $\sigma$ is much greater than $\sigma_{1}$. Econometric estimates of cost functions for aggregate production technologies generally imply that $F_{K N}$ is greater than zero.

9. With respect to wages, the condition on $\partial w_{1} / \partial P_{N_{1}}$ less than zero is analogously given by $F_{L N}$ greater than zero. On the other hand, because $\partial Q_{2} / \partial L_{2}, \partial Q_{2} / \partial K_{2}$, and $\partial Q_{2} / \partial N_{2}$ lie on a factor-price frontier, we must have declining $w_{2}$ (equal to $\partial Q_{2} / \partial L_{2}$ ) when $P_{N_{2}}$ (equal to $\partial Q_{2} / \partial N_{2}$ ) rises, as long as $1+r$ (equal to $\left.\partial Q_{2} / \partial K_{2}\right)$ is unchanged. 
The value of firms, $V$, is the discounted value of dividend payments. Assuming that investment is financed by retained earnings (which is without loss of generality), first-period dividends are $Q_{1}-P_{N_{1}} N_{1}-$ $w_{1} L_{1}-I_{1}$; second-period dividends are $Q_{2}-P_{N_{2}} N_{2}-w_{2} L_{2}$. Thus,

$$
V=\left(Q_{1}-P_{N_{1}} N_{1}-w_{1} L_{1}-I_{1}\right)+\left(Q_{2}-P_{N_{2}} N_{2}-w_{2} L_{2}\right) /(1+r) .
$$

Finally, the value of domestic oil, $N^{v}$, is given by

$$
N^{v}=P_{N_{1}} N_{1}^{H}+\left(P_{N_{2}} N_{2}^{H}\right) /(1+r) .
$$

It is convenient to assemble these pieces and rewrite wealth as

$$
\begin{aligned}
W= & {\left[Q_{1}-G_{1}-I_{1}+P_{N_{1}}\left(N_{1}^{H}-N_{1}\right)\right] } \\
& +\left[Q_{2}-G_{2}+P_{N_{2}}\left(N_{2}^{H}-N_{2}\right)\right] /(1+r),
\end{aligned}
$$

where use has been made of the two-period government budget constraint,

$$
G_{1}+\frac{G_{2}}{1+r}=T_{1}+\frac{T_{2}}{1+r} .
$$

I denote the expressions in brackets from equation 8 with the symbols $Z_{1}$ and $Z_{2}$, respectively. Note that these expressions are the GDP net of government spending and investment for each period because GDP in domestic goods units is $Q_{1}+P_{N i}\left(N_{i}^{H}-N_{i}\right) .^{10}$

In general, current consumption can be written as a function of wealth and $r: C_{1}=C_{1}(W, r)$. I consider the case of an additively separable, isoelastic utility function in $C_{1}$ and $C_{2}$,

$$
U\left(C_{1}, C_{2}\right)=\frac{C_{1}^{(1-\gamma)}}{1-\gamma}+\left(\frac{1}{1+\delta}\right) \frac{C_{2}^{(1-\gamma)}}{1-\gamma} \quad \delta, \gamma \geq 0,
$$

where $\delta$ is the rate of time preference and $\gamma$ is a measure of curvature of the function. For this function, consumption is linear in wealth; specifically,

$$
C_{1}=\lambda W \quad \lambda=\left[1+\left(\frac{1}{1+r}\right)\left(\frac{1+r}{1+\delta}\right)^{1 / \gamma}\right]^{-1} .
$$

10. A tricky point is that $Q_{i}+P_{N_{i}}\left(N_{i}^{H}-N_{i}\right)$ is real GDP using a single-deflation method (that is, nominal GDP divided by the price of home output), but is not the standard measure of real GDP using the typical double-deflation method. For this, $N_{i}^{H}-N_{i}$ is multiplied by a base-period real price of oil so that real GDP becomes $Q_{i}+P_{N_{0}}\left(N_{i}^{H}-N_{i}\right)$. 
From equation 7, $C_{2}=(1+r)\left(W-C_{1}\right)$, so $C_{2}$ is also linear in wealth. Note that $C_{1} \gtreqless C_{2}$ as $r \lesseqgtr \delta$. The importance of various assumptions about the utility function for the current account has been studied in an excellent recent work by Razin and Svensson. ${ }^{11}$

Now it is possible to solve for the current account. In each period, net exports of the produced good are given by $Q_{i}-C_{i}-G_{i}-I_{i}$, while net exports of the input in terms of final product are given as $P_{N_{1}}\left(N_{i}^{H}-N_{i}\right)$. The first-period current account is therefore equal to

$$
C A_{1}=\left(Q_{1}-C_{1}-G_{1}-I_{1}\right)+P_{N_{1}}\left(N_{1}^{H}-N_{1}\right) .
$$

Clearly, $C A_{1}=Z_{1}-C_{1}$ by definition of $Z_{1}$. And, from the various budget constraints, it is easy to show that $C A_{2}=-C A_{1}$.

\section{THE RESPONSE TO SHOCKS}

Figure 1, based on the budget constraint $C_{1}+C_{2} /(1+r)=Z_{1}+$ $Z_{2} /(1+r)$ shows the effects of various shocks on $C A_{1}$. (Analytical expressions for $C A_{1}$ are in general complicated and are derived in an appendix available from the author.) In figure 1 , the intertemporal budget constraint is represented by the line through $Z=\left(Z_{1}, Z_{2}\right)$ with slope $-(1+r)$. The linearity of the schedule results from the assumptions of perfect capital mobility and fixed terms of trade between home and foreign output. The consumption choice $C=\left(C_{1}, C_{2}\right)$ is at the tangency of the indifference curve with the budget constraint. The first-period current account balance is $Z_{1}-C_{1}$. Because $Z_{1}$ is greater than $C_{1}$ in the diagram, a first-period surplus results.

Consider next the effects on $C A_{1}$ of movements in the exogenous variables $\theta_{i}, P_{N i}$, and $G_{i}$. Because $Z_{1}=Q_{1}-I_{1}+P_{N_{1}}\left(N_{1}^{H}-N_{1}\right)-G_{1}$ and $Z_{2}=Q_{2}+P_{N_{2}}\left(N_{2}^{H}-N_{2}\right)-G_{2}$, other things being equal, positive shocks to $Q_{1}$ raise $Z_{1}$, shocks to $G_{1}$ lower $Z_{1}$, and shocks to $P_{N_{1}}$ raise $Z_{1}$ if and only if $N_{1}^{H}$ is greater than $N_{1}$. Anticipated positive shocks to $\theta_{2}$ raise $Z_{2}$ while lowering $Z_{1}$ because of an induced increase in investment. Similarly, higher $P_{N_{2}}$ raises $Z_{1}$ because of the negative investment effect while raising

11. It is unfortunate that their study arrived too late for incorporation into this paper, although there are obvious similarities in approach. See Lars E. O. Svensson and Assof Razin, "The Terms of Trade, Spending, and the Current Account: The Harberger-Laursen-Metzler Effect," Seminar Paper 170 (University of Stockholm, Institute for International Economic Studies, March 1981). 
Figure 1. Determination of the Current Account

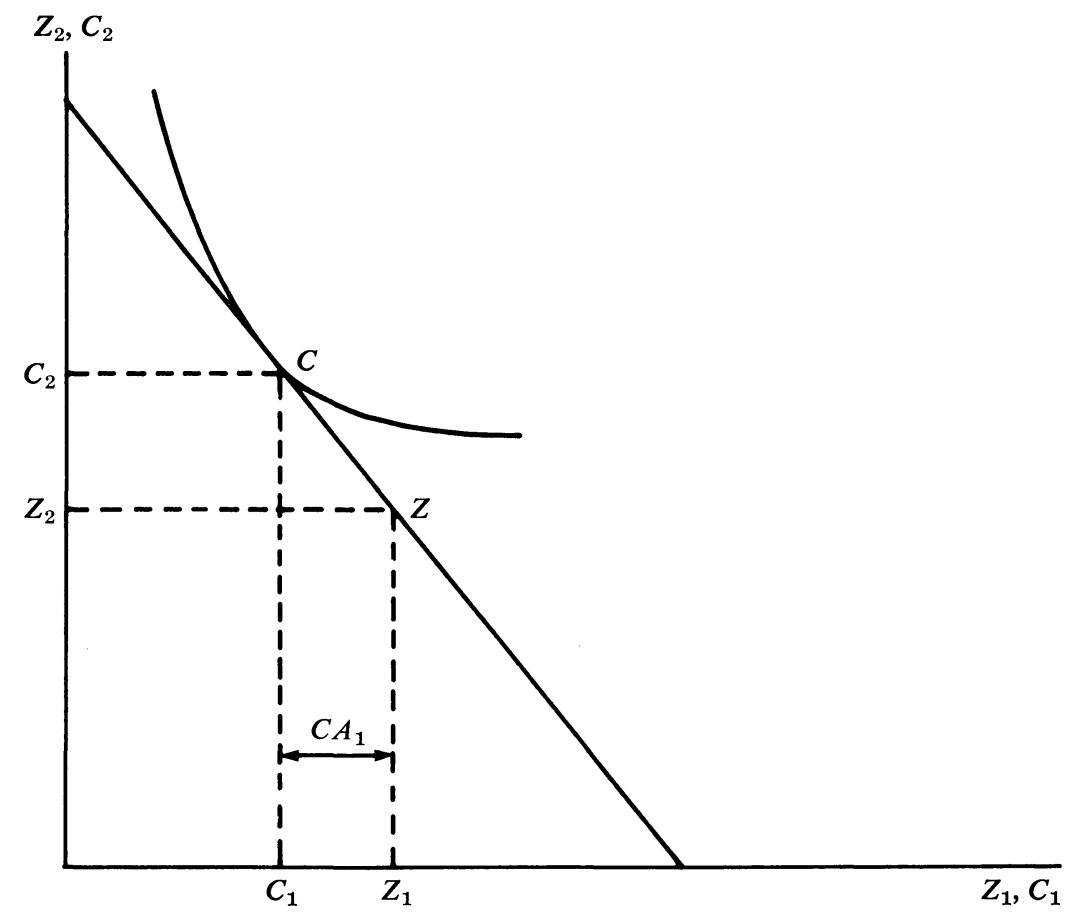

or lowering $Z_{2}$, depending on whether $N_{2}^{H}$ is greater or less than $N_{2}$. Higher $G_{2}$ necessarily lowers $Z_{2}$.

Figure 2 illustrates the crucial difference in effect of temporary and permanent shifts in $Z$, without having to be explicit about which of the underlying shocks is moving $Z$. The two shocks in the figure have the same drop in $Z_{1}$; one is accompanied by a decline in $Z_{2}$ (a "permanent" decline), the other is not (a "temporary" decline). The first represents a greater reduction in wealth and hence consumption possibilities. The shifts are shown as the movement from $Z$ to $Z^{P}$ and to $Z^{T}$, respectively. Generally a temporary decline in $Z$ leads to a much larger fall in the surplus (or rise in the deficit) than does a permanent drop. With a temporary shortfall, households spread some of the loss to the second period, thus dissaving to smooth consumption over time; with a permanent decline in $Z$, households do not borrow against second-period income. When $Z_{1}$ and $Z_{2}$ fall in equal proportions, $C A_{1}$ also falls in the same propor- 
Figure 2. Temporary versus Permanent Shifts in $Z$

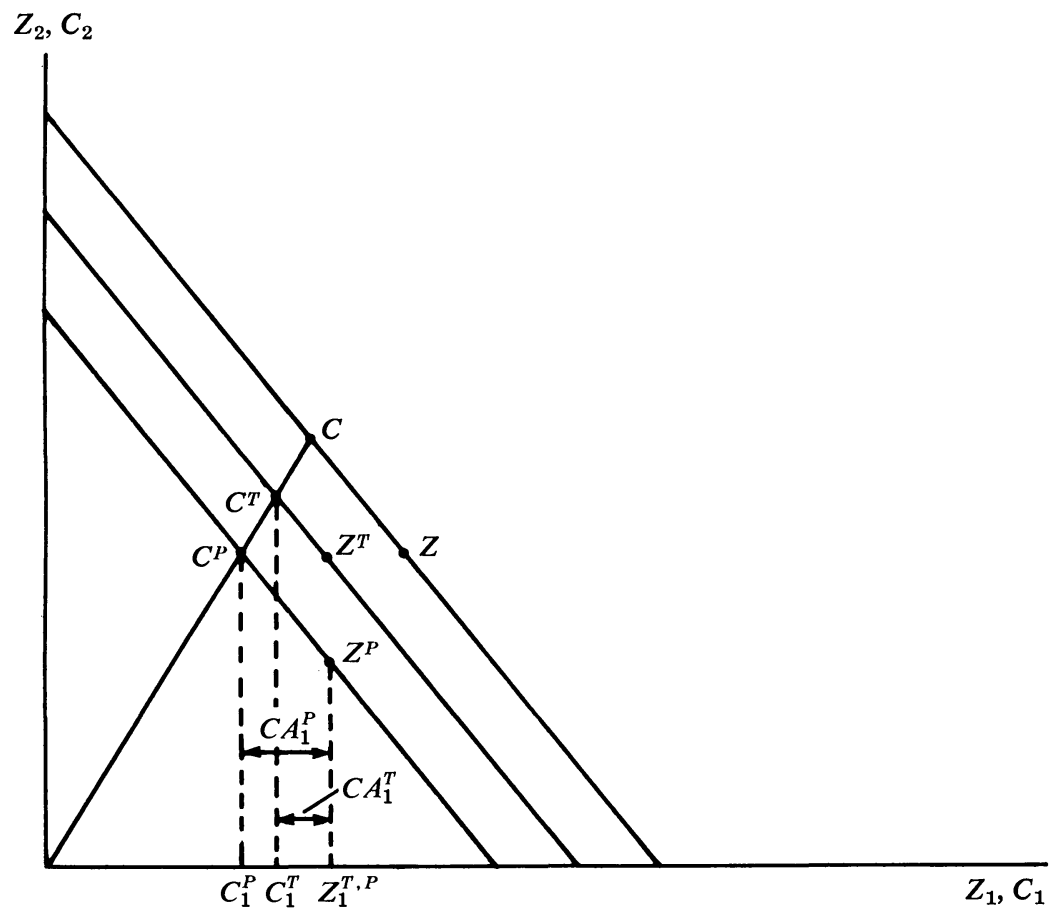

tion. Initial surpluses or deficits become smaller. From a position of initial current account balance, a proportionate reduction in $Z_{1}$ and $Z_{2}$ leaves the current account unchanged.

Consumption depends on the discounted sum of $Z$ - private wealthbut not its time profile. Hence if output is rising, there is likely to be a firstperiod deficit and a second-period surplus, whereas if output is falling there may be a first-period surplus. Thus, as illustrated in figure 3 , the profile $Z^{0}$ leads to a surplus and $Z^{1}$ to a deficit. Households save more in the $Z^{0}$ case in anticipation of the decline in $Z$. A comparison of $Z^{0}$ and $Z^{1}$ illustrates the effect of a shock, such as a fiscal spending increase, which changes the time profile but not the discounted value of $Z$. A temporary rise in government spending ( $G_{1}$ rising and $G_{2}$ falling so that $G_{1}+G_{2}$ / $(1+r)$ is constant) is represented by a change from $Z^{0}$ to $Z^{1}$. The current account changes from a surplus, $C A_{1}^{0}$, to a deficit, $C A_{1}^{1}$. 
Figure 3. The Effects of Alternative Income Profiles

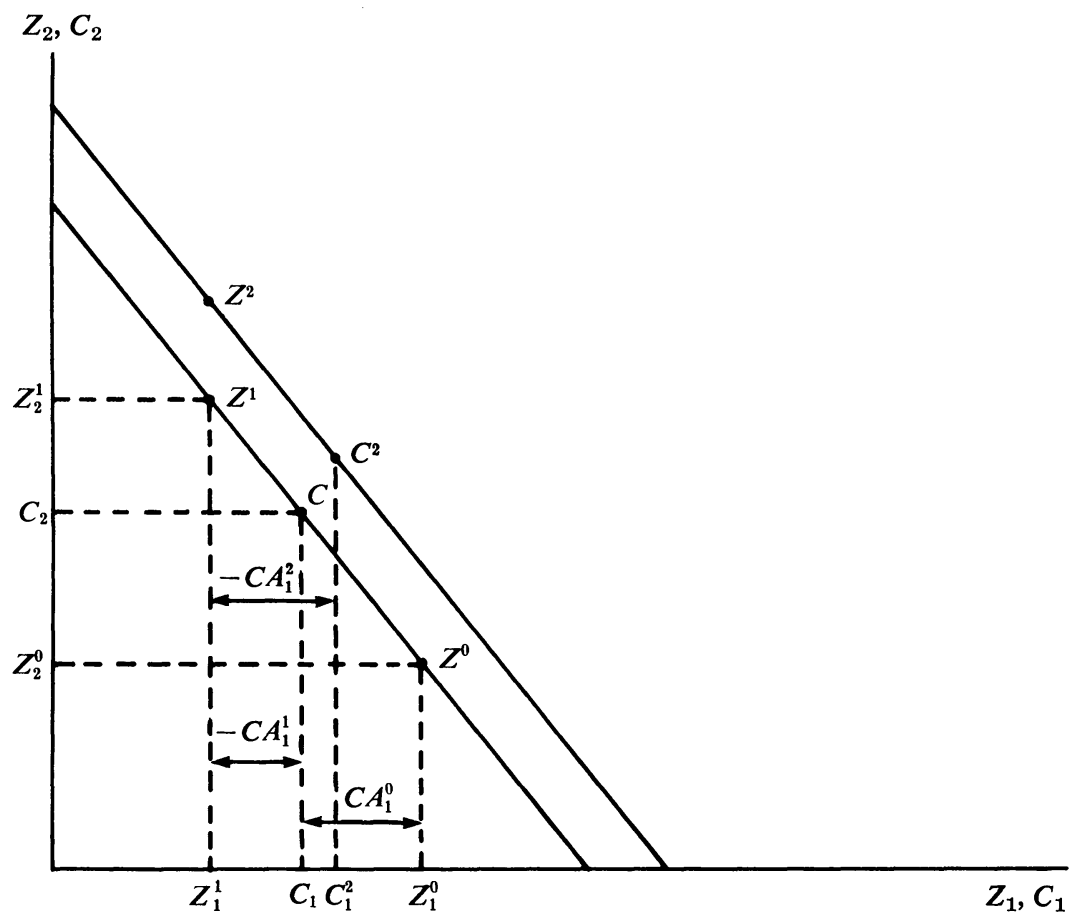

Figure 3 also illustrates the effects of shifts in investment. Suppose, for purposes of illustration, there is a rise in physical investment that just earns the market rate of return. Then $Z^{0}$ shifts to $Z^{1}\left(Z_{1}\right.$ falls by $I$ and $Z_{2}$ rises by $I(1+r))$, leaving the economy on the original budget constraint. Because the rise in $I$ does not affect total wealth and hence consumption, the current account worsens by precisely the amount of the investment boom. Households regard corporate investment as a perfect substitute for personal saving because both earn the market interest rate, $r$, and because households own the firms. More typically, with a shift in technical productivity (a change in $\theta_{2}$ ) inframarginal investments earn more than the market rate of return. Here the decline in $C A_{1}$ following the investment is greater than on a one-to-one basis. This is shown in figure 3 by the movement from $Z^{0}$ to $Z^{2}$.

As this discussion illustrates, in this model, temporary slumps in out- 
put and $Z$ are associated with deficits, and booms with surpluses. This is opposite the conclusion from the usual Keynesian analysis and from the conventional wisdom about the cyclical fluctuations in the current account. The empirical links between output fluctuations and the current account appear to be rather weak for the OECD economies, and moreover, to the extent that such links exist, it appears that the drop in $I$ during a recession, not output, explains the association between current account surpluses and recession.

\section{OIL PRICE SHOCKS}

Next, consider the effects of a rise in oil prices that is perceived to be permanent. If there are no investment consequences to an increase in oil prices, the effects are simply those of a permanent income change. $Z_{1}$ and $Z_{2}$ fall for net importers and rise for net exporters. The greater the dependence on imported oil, the larger is the fall in $C_{1}$ and $C_{2}$ after an oil-price shock. But there should be no tendency for oil-dependent economies to run larger deficits than oil-exporting countries. The $C A_{1}$ shifts in proportion to $Z_{1}$ when $Z_{1}$ and $Z_{2}$ change in equal proportion. The depressing effects of oil price increases on investment tend to improve the current account for both oil exporters and importers.

Unlike a permanent price shock, a temporary rise in $P_{N}$ has opposite first-period effects for oil exporters and importers: the exporter has an increase in wealth and will spread the gain over time, running a surplus; the importer will borrow from the second period in which oil bills will not be as much of a burden.

In two important ways the model must be modified when used to describe short-run behavior, particularly that of the large oil-exporting countries. The model abstracts from cyclical demand effects that may have come from the oil shock and the responses of government to it. The model assumes that there are no perception lags or costs to rapid adjustment of consumption following an oil price rise. Different short-run results are obtained if $C_{1}$ adjusts to its new equilibrium slowly after a shock. For a major oil producer the required upward adjustment in $C_{1}$ may be several hundred percent, and physical bottlenecks alone may slow such a significant rise in consumption. Costs of adjustment to raising $C_{1}$ were dramatically illustrated when cement-carrying ships were trapped for months outside the inadequate port at Lagos, Nigeria, after the post-1973 boom 
in spending. Many studies of "high absorber" versus "low absorber" OPEC countries have investigated these costs of adjustment. ${ }^{12}$

Adjustment costs provide one explanation for a high marginal propensity to save of OPEC members following an oil-price increase. The nonrenewable nature of oil reserves provides another. When $N_{2}^{H}$ is much less than $N_{1}^{H}$, even a permanent rise in $P_{N}$ has the effect of a transitory increase in oil-exprot earnings. If $P_{N}$ is not expected to fall, the OPEC countries face the prospect of declining income in future years. (Thus a transitory shock for an oil producer may be a permanent shock for an importing country.) Because OPEC's current GDP exceeds long-run GDP, OPEC members have the incentive to accumulate financial assets to smooth consumption over time. In the model, this is described as a declining $Z$ profile, which results in surpluses.

A second important modification to the model for short-run analysis may help to explain oil-exporter deficits. To the extent that oil production itself requires physical investment, a rise in $\boldsymbol{P}_{N}$ may generate a particularly large rise in $I_{1}$ in oil-rich economies, so that these countries may have deficits caused by an investment boom like that illustrated in figure 3 . Empirically this effect clearly shows up within the OECD countries.

\section{Interest Rates and Equilibrium}

Thus far in the discussion the world interest rate has been taken as exogenous. In this section, I emphasize its important role in equilibrating world output and capital markets. Reductions in $r^{*}$ and the induced changes in investment help to explain the huge deficit of oil-importing countries since 1973. In the absence of such reductions one would expect oil price rises to lead to surpluses in the oil-importing countries. There is in reality no single, world interest rate; $r^{*}$ should be regarded as a proxy for a vector of rates in different countries that move more or less in tandem.

Just as the current account equilibrium within a country can be variously described, the condition for equilibrium of the world capital market, still assuming full employment, can be stated in a number of ways: world investment equals world saving; the sum of current account surpluses

12. For a discussion, $\rightarrow$ David R. Morgan, "Fiscal Policy in Oil Exporting Countries, 1972-78," IMF Staff Papers, vol. 26 (March 1979), pp. 55-81. 
is zero; world output supply equals world output demand. In general, if desired world saving exceeds desired world investment, one would expect the world interest rate to fall, just as the domestic real interest rate is expected to decline in a closed economy. A drop in $r^{*}$ tends to raise investment and increase consumption relative to income in the various countries, thus reducing world saving and raising world investment until output and capital markets clear. This adjustment mechanism must be qualified because net saving is not necessarily a monotonically increasing function of the interest rate.

This reasoning implies that a permanent OPEC price rise should have a depressing effect on the world real interest rate. As shown above, at an initial $r^{*}$, the rise in $P_{N}$ will lead to a desired surplus in the oil-importing countries. Investment will tend to fall because of the complementarity of oil and capital. Consumption will drop by about as much as real GDP at the time of the price increase, so that dissaving is not required to pay for higher oil imports. And OPEC countries are also likely to want a surplus at the initial $r^{*}$, as I have argued. If these conditions hold, an incipient excess supply of world output develops, and $r^{*}$ must fall until desired OPEC surpluses are matched by desired deficits among oil-consuming economies. Put another way, $r^{*}$ falls because investment demand falls and income is redistributed to the OPEC region, which has a relatively low propensity to consume.

Two major caveats are in order. First, if the rise in $P_{N}$ is perceived as temporary, the oil-importing countries will want deficits at the initial interest rate. It is possible that these desired deficits and the OPEC surplus balance at the initial interest rate, so that $r^{*}$ need not decline. Second, relaxing the full employment assumption, if higher $P_{N}$ leads to a significant cyclical contraction in the importing countries, households may choose to dissave at the initial interest rate, borrowing against higher future income. Again, the decline in $r^{*}$ may not occur.

Table 6 shows the changes in ex post real interest rates (measured in terms of the national GNP deflator) in four major OECD economies between 1965 and 1979. There is a clear and consistent drop of real rates of interest after 1973.

The ex post rate is assumed to be a proxy for the unobserved ex ante rate, which is the appropriate rate for saving and investment decisions. This assumption was also made by Mishkin, who recently documented the decline in ex post U.S. real interest rates after 1973. Because the 1973-74 period of oil shock was also a time of unanticipated inflation, 
Table 6. Real Interest Rates, Major Industrial Countries, Selected Years and Periods, 1965-79a

\begin{tabular}{lrlrrrrrrr}
\hline \multirow{2}{*}{ Country } & \multicolumn{2}{c}{ Average } & & & & & & & \\
\cline { 2 - 9 } & $1965-72$ & $1973-79$ & 1973 & 1974 & 1975 & 1976 & 1977 & 1978 & 1979 \\
\hline United States & 0.7 & -0.6 & -0.5 & -3.0 & -0.2 & -0.3 & -0.8 & -1.8 & 1.9 \\
United Kingdom & 0.2 & -5.4 & -1.3 & -17.8 & -6.2 & -1.9 & -4.7 & -1.2 & -4.5 \\
Germany & -0.5 & -0.6 & 0.2 & -2.6 & 0.2 & -0.3 & -1.3 & -1.1 & 0.6 \\
Japan & 0.4 & -2.2 & -14.1 & -7.5 & 1.6 & -0.6 & 1.0 & 0.2 & 4.3 \\
\hline
\end{tabular}

Sources: Interest rates for all countries and prices for the United States and the United KingdomOrganisation for Economic Co-operation and Development, Main Economic Indicators, various issues; prices for Japan and Germany-International Monetary Fund, International Financial Statistics, various issues.

a. Calculated as the average for the year of the difference between the quarterly average Treasury bill rate and the change, at an annual rate, in the GNP deflator from one period to the next.

the ex post rates are probably underestimates of the ex ante rates. In another recent, unpublished study, James Wilcox directly tests for the role of import prices in determining the nominal interest rate in the United States in 1972-78. In a regression of nominal interest rates on expected inflation (using the Livingston expectations data), monetary and fiscal variables, the relative price of imports, and domestic GNP (serving as a proxy for the oil price hike), Wilcox confirms a large and robust negative relationship between real import prices and the interest rate, holding expectations constant. ${ }^{13}$

\section{Extensions of the Theory of the Current Account}

The basic view that the current account results from intertemporal savings and investment decisions of domestic agents can be elaborated in a variety of directions. In this section, I discuss the effects on the current account of demand-induced fluctuations in output, capital controls, fiscal policy, and changes in the terms of trade of final goods.

\section{FLUCTUATIONS IN OUTPUT}

Until this point, output fluctuations have been taken as exogenous or as supply-side responses to exogenous shifts in technology, $\theta$, and input

13. See Frederic S. Mishkin, "The Real Interest Rate: An Empirical Investigation," Working Paper 622 (National Bureau of Economic Research, January 1981); and James A. Wilcox, "Interest Rates, Expected Inflation, and Supply Shocks or Why Interest Rates Have Been So Low in the 1970's," paper presented at the NBER Conference on Inflation and Financial Markets, May 1981. 
price changes, $P_{N}$. With these types of shocks, temporary reductions in output (or more generally, $Z$ ) lead to deficits, and booms to surpluses. This response follows from the assumption about how a household's saving responds to transitory income shocks but does not fit with the conventional macroeconomic view that booms lead to deficits as high income causes a rise in demand for imports.

The apparent contradiction is easily resolved. The correlation of $Q$ and $C A$ should critically depend on the underlying shocks moving these variables. A temporary rise in $\theta_{1}$ or fall in $P_{N_{1}}$ causes both $C A_{1}$ and $Q_{1}$ to rise. Alternatively, a temporary increase in $G_{1}$, or an anticipated rise in $\theta_{2}$ or fall in $P_{N_{2}}$, causes $C A_{1}$ to fall, and may cause $Q_{1}$ to rise if aggregate demand shifts affect output on Keynesian grounds. A negative statistical correlation between $C A_{1}$ and $Q_{1}$ will result. Demand-induced increases in output tend to increase saving and hence augment the current account effects of a change in $\theta_{1}$ and partially offset the effects of a change in $\theta_{2}, P_{N_{2}}$, or $G_{1}$. Consider, for example, an investment boom following a rise in $\theta_{2}$. If $Q_{1}$ increases in response to the rise in $I_{1}$, household saving will also increase and in part pay for the higher $I_{1}$. The $C A_{1}$ will not fall as much as in the case of fixed $Q_{1}$.

It is likely that fluctuations in $I$ jointly affect $Q$ and $C A$ and account for the negative simple correlation of $Q$ and $C A$. As shown in table 7, the predominantly negative coefficients on GNP relative to trend, represented by $G N P$ gap, in explaining $C A$ are generally less significant and less negative when $I$ is included in the regressions. By contrast, the effects of investment are almost always negative and frequently significantly so. In principle, shifts in consumption demand or government expenditures should also induce a negative correlation between output and the current account. It appears that the effects of variations in these other demands have been largely offset by variations in $\theta$ or in export demands, both of which would lead to a positive correlation between output and $C A$.

\section{CAPITAL CONTROLS}

Another important step in bringing the basic model closer to reality is the introduction of capital controls. A prime instrument for a country to use in achieving current account objectives is a regulatory restriction on international borrowing and lending. For a small economy with perfect capital mobility, investment and saving and hence the current account 
depend on world interest rates, which are exogenous. If binding capital restrictions are imposed, the home interest rate may deviate from the world rate; the home rate adjusts until a current account balance is achieved that is consistent with the capital controls. One common type of control is a ceiling on net new foreign borrowing, so that $C A$ is fixed at $\overline{C A}$. Solution of the model in this case simply involves finding the $r$ that yields $\overline{C A}$. More sophisticated controls may impose, in effect, a rising tax rate on incremental foreign borrowing. With such controls, $r=r^{*}+f(C A)$, $f^{\prime}<0$; and $r$ and $C A$ are determined simultaneously. The endogeneity of home $r$ quantitatively but not qualitatively affects certain key results of the last section. A rise in $\theta_{2}$ under perfect capital mobility may lead to a large $C A$ deficit reflecting induced investment demand and a decline in saving, as households borrow against higher future income. With imperfect capital mobility, a boom in investment opportunities will be financed less by foreign capital inflows and more by the domestic saving induced by an increase in home interest rates.

\section{FISCAL POLICY}

Countries may also pursue current account objectives with fiscal instruments. It was shown above that temporary cuts in government spending provide a powerful vehicle for increasing $C A_{1}$, while permanent reductions in $G$ (for example, equal cuts in $G_{1}$ and $G_{2}$ ) may have negligible or perverse effects on the current account. An unrealistic aspect of the model is that labor income tax policy, as distinct from spending policy, has no effect on the current account (to verify this point, note that $Z_{1}, Z_{2}$, and hence $C_{1}$ are not functions of $T_{1}$ and $T_{2}$ ). This result reflects the assumption that households internalize the government's intertemporal budget constraint in choosing their consumption path; the assumption's plausibility depends on whether households have perfect foresight and a planning horizon that matches the horizon of the economy. These particular assumptions have been persuasively challenged in recent work. ${ }^{14}$ It is more plausible that households pierce the "corporate veil" than the government veil in making saving decisions, because the former does not require that the planning horizon of households match that of the econ-

14. See William H. Buiter and James Tobin, "Debt Neutrality: A Brief Review of Doctrine and Evidence," in George M. von Furstenberg, ed., Social Security vs. Private Saving (Ballinger, 1980), pp. 39-63. 
Table 7. Explaining the Current Account with Investment and the GNP Gap,

Developed Countries, 1960-79a

\begin{tabular}{|c|c|c|c|c|c|}
\hline \multirow[b]{3}{*}{$\begin{array}{l}\text { Country and } \\
\text { equation }\end{array}$} & \multicolumn{3}{|c|}{ Independent variable } & \multirow{2}{*}{\multicolumn{2}{|c|}{ Summary statistic }} \\
\hline & \multirow[b]{2}{*}{$\begin{array}{l}\text { GNP } \\
\text { gap }\end{array}$} & \multirow{2}{*}{$\begin{array}{l}\text { Ratio of invest- } \\
\text { ment to GNP } \\
\quad(I / G N P)\end{array}$} & \multirow[b]{2}{*}{ Time } & & \\
\hline & & & & $\bar{R}^{2}$ & $\begin{array}{l}\text { Durbin- } \\
\text { Watson }\end{array}$ \\
\hline \multicolumn{6}{|l|}{ Australia } \\
\hline $7-1$ & $\begin{array}{l}-0.145 \\
(-0.7)\end{array}$ & $\ldots$ & $\begin{array}{l}0.0010 \\
(1.4)\end{array}$ & 0.00 & 1.40 \\
\hline $7-2$ & $\begin{array}{l}-0.04 \\
(-0.1)\end{array}$ & $\begin{array}{l}-0.44 \\
(-1.4)\end{array}$ & $\begin{array}{l}0.0000 \\
(0.0)\end{array}$ & 0.50 & 1.50 \\
\hline \multicolumn{6}{|l|}{ Austria } \\
\hline $7-3$ & $\begin{array}{l}-0.07 \\
(-0.5)\end{array}$ & $\cdots$ & $\begin{array}{l}-0.0004 \\
(-0.79)\end{array}$ & -0.10 & 1.30 \\
\hline $7-4$ & $\begin{array}{l}-0.02 \\
(-0.1)\end{array}$ & $\begin{array}{l}-0.23 \\
(-1.0)\end{array}$ & $\begin{array}{l}0.0000 \\
(0.0)\end{array}$ & -0.09 & 1.34 \\
\hline \multicolumn{6}{|l|}{ Belgium } \\
\hline $7-5$ & $\begin{array}{l}-0.18 \\
(-0.7)\end{array}$ & $\ldots$ & $\begin{array}{l}0.0000 \\
(0.14)\end{array}$ & -0.08 & 0.52 \\
\hline $7-6$ & $\begin{array}{l}-0.16 \\
(-0.6)\end{array}$ & $\begin{array}{r}0.33 \\
(0.8)\end{array}$ & $\begin{array}{l}-0.0002 \\
(-0.4)\end{array}$ & -0.10 & 0.55 \\
\hline \multicolumn{6}{|l|}{ Canada } \\
\hline $7-7$ & $\begin{array}{l}-0.47 \\
(-2.4)\end{array}$ & $\cdots$ & $\begin{array}{l}0.0004 \\
(1.0)\end{array}$ & 0.17 & 1.12 \\
\hline $7-8$ & $\begin{array}{l}-0.38 \\
(-1.4)\end{array}$ & $\begin{array}{l}-0.17 \\
(-0.5)\end{array}$ & $\begin{array}{l}0.0005 \\
(1.1)\end{array}$ & 0.14 & 0.96 \\
\hline \multicolumn{6}{|l|}{ Denmark } \\
\hline $7-9$ & $\begin{array}{l}-0.36 \\
(-3.0)\end{array}$ & $\ldots$ & $\begin{array}{l}-0.0017 \\
(-4.1)\end{array}$ & 0.46 & 1.88 \\
\hline $7-10$ & $\begin{array}{l}-0.40 \\
(-3.0)\end{array}$ & $\begin{array}{l}0.129 \\
(0.8)\end{array}$ & $\begin{array}{l}-0.0019 \\
(-3.8)\end{array}$ & 0.45 & 2.09 \\
\hline \multicolumn{6}{|l|}{ Finland } \\
\hline $7-11$ & $\begin{array}{l}-0.38 \\
(-2.0)\end{array}$ & $\cdots$ & $\begin{array}{l}-0.0000 \\
(-0.9)\end{array}$ & 0.12 & 0.91 \\
\hline $7-12$ & $\begin{array}{l}0.03 \\
(0.2)\end{array}$ & $\begin{array}{l}-0.76 \\
(-3.9)\end{array}$ & $\begin{array}{l}0.0000 \\
(0.2)\end{array}$ & 0.54 & 1.30 \\
\hline \multicolumn{6}{|l|}{ France } \\
\hline $7-13$ & $\begin{array}{l}-0.05 \\
(-0.1)\end{array}$ & $\ldots$ & $\begin{array}{l}0.0020 \\
(0.3)\end{array}$ & 0.20 & 1.87 \\
\hline $7-14$ & $\begin{array}{l}-0.04 \\
(-0.1)\end{array}$ & $\begin{array}{l}-0.78 \\
(-2.1)\end{array}$ & $\begin{array}{l}-0.0010 \\
(-1.2)\end{array}$ & 0.13 & 1.76 \\
\hline \multicolumn{6}{|l|}{ Germany } \\
\hline $7-15$ & $\begin{array}{l}-0.26 \\
(-2.5)\end{array}$ & $\cdots$ & $\begin{array}{l}-0.0001 \\
(-0.5)\end{array}$ & 0.20 & 1.46 \\
\hline $7-16$ & $\begin{array}{l}-0.09 \\
(-2.6)\end{array}$ & $\begin{array}{l}-0.28 \\
(-1.4)\end{array}$ & $\begin{array}{l}-0.0005 \\
(-1.3)\end{array}$ & 0.24 & 1.32 \\
\hline
\end{tabular}


Table 7 (continued)

\begin{tabular}{|c|c|c|c|c|c|}
\hline \multirow[b]{3}{*}{$\begin{array}{c}\text { Country and } \\
\text { equation }\end{array}$} & \multicolumn{3}{|c|}{ Independent variable } & \multirow{2}{*}{\multicolumn{2}{|c|}{ Summary statistic }} \\
\hline & & Ratio of invest- & & & \\
\hline & $\begin{array}{l}\text { GNP } \\
\text { gap }\end{array}$ & $\begin{array}{c}\text { ment to } G N P \\
(I / G N P)\end{array}$ & Time & $\bar{R}^{2}$ & $\begin{array}{l}\text { Durbin- } \\
\text { Watson }\end{array}$ \\
\hline \multicolumn{6}{|l|}{ Italy } \\
\hline $7-17$ & $\begin{array}{l}-0.12 \\
(-0.5)\end{array}$ & $\cdots$ & $\begin{array}{l}-0.0010 \\
(-1.0)\end{array}$ & -0.05 & 0.83 \\
\hline $7-18$ & $\begin{array}{l}0.20 \\
(1.2)\end{array}$ & $\begin{array}{l}-1.18 \\
(-5.1)\end{array}$ & $\begin{array}{l}-0.0020 \\
(-2.8)\end{array}$ & 0.57 & 1.62 \\
\hline \multicolumn{6}{|l|}{ Japan } \\
\hline $7-19$ & $\begin{array}{r}0.07 \\
(0.8)\end{array}$ & $\cdots$ & $\begin{array}{l}0.0009 \\
(1.6)\end{array}$ & 0.03 & 1.36 \\
\hline $7-20$ & $\begin{array}{c}0.11 \\
(1.0)\end{array}$ & $\begin{array}{l}-0.12 \\
(-0.7)\end{array}$ & $\begin{array}{l}0.0009 \\
(1.7)\end{array}$ & 0.00 & 1.33 \\
\hline \multicolumn{6}{|l|}{ Netherlands } \\
\hline $7-21$ & $\begin{array}{l}0.055 \\
(0.2)\end{array}$ & $\ldots$ & $\begin{array}{l}0.0000 \\
(0.08)\end{array}$ & -0.12 & 0.64 \\
\hline $7-22$ & $\begin{array}{c}0.12 \\
(0.5)\end{array}$ & $\begin{array}{l}-0.67 \\
(-3.0)\end{array}$ & $\begin{array}{l}-0.0010 \\
(-1.9)\end{array}$ & 0.12 & 0.60 \\
\hline \multicolumn{6}{|l|}{ Norway } \\
\hline $7-23$ & $\begin{array}{c}-0.09 \\
(-0.53)\end{array}$ & $\ldots$ & $\begin{array}{l}-0.0040 \\
(-1.9)\end{array}$ & 0.16 & 0.83 \\
\hline $7-24$ & $\begin{array}{l}0.16 \\
(1.8)\end{array}$ & $\begin{array}{l}-0.93 \\
(-7.2)\end{array}$ & $\begin{array}{l}0.0004 \\
(0.3)\end{array}$ & 0.79 & 1.98 \\
\hline \multicolumn{6}{|l|}{$\begin{array}{l}\text { United } \\
\quad \text { Kingdom }\end{array}$} \\
\hline $7-25$ & $\begin{array}{l}-0.14 \\
(-0.7)\end{array}$ & $\ldots$ & $\begin{array}{l}-0.0005 \\
(-1.0)\end{array}$ & -0.04 & 1.00 \\
\hline $7-26$ & $\begin{array}{l}-0.23 \\
(-1.3)\end{array}$ & $\begin{array}{l}-0.87 \\
(-2.4)\end{array}$ & $\begin{array}{l}0.0002 \\
(-0.4)\end{array}$ & 0.19 & 1.10 \\
\hline \multicolumn{6}{|l|}{ United States } \\
\hline $7-27$ & $\begin{array}{l}-0.06 \\
(-1.8)\end{array}$ & $\ldots$ & $\begin{array}{l}-0.0006 \\
(-3.7)\end{array}$ & 0.38 & 1.56 \\
\hline $7-28$ & $\begin{array}{l}-0.03 \\
(-0.8)\end{array}$ & $\begin{array}{l}-0.22 \\
(-1.2)\end{array}$ & $\begin{array}{l}-0.0003 \\
(-1.4)\end{array}$ & 0.40 & 1.57 \\
\hline
\end{tabular}

Sources: Calculations by the author. Current account-Organisation for Economic Co-operation and Development, Main Economic Indicators; GNP and fixed capital formation for all countries except the United States-International Monetary Fund, International Financial Statistics; U.S. fixed capital formation-OECD, National Accounts of OECD Countries, 1950-78 (Paris: OECD, 1980) and recent supplements.

a. The dependent variable is the current account balance as a proportion of GNP. The GNP gap is calculated as log (GNP/GNP trend), where GNP trend is constructed by fitting trend lines between the logarithm of GNP in 1960 and 1973 and in 1973 and 1979 . The $I / G N P$ is gross fixed capital formation as a proportion of GNP. The numbers in parentheses are $t$-statistics. 
omy. Moreover, retained earnings of firms are presumably capitalized in the stock market, while future tax liabilities are not bought and sold, and thereby valued, in organized markets.

\section{TERMS-OF-TRADE EFFECTS}

Another unrealistic feature of the model is the assumption of one final good. The model can be extended to examine the implications of individual economies producing distinct final goods that may be imperfect substitutes in consumption and investment. Let $P$ be the price of the home final good and $P^{*}$ the foreign price of the foreign final good. Now $P / e P^{*}$ and $r$ simultaneously adjust to equilibrate home and foreign output markets and balance global saving and investment. An important intermediate case between the models for small and large countries is one in which the economy is small in import markets, taking $r^{*}$ and $P_{N}^{*} / P^{*}$ as fixed, but large in the export market, facing a downward sloping demand schedule for exports. In this case, fluctuations in export demand are reintroduced as a determinant of the $C A$ balance; they have no separate role in the model described above.

Once again, it is important to recognize the difference between permanent and temporary shocks. Permanent shocks to export demand have little effect on the current account, while temporary fluctuations may have a large effect. A permanent increase in export demand raises $P / e P^{*}$ but does not necessarily affect intertemporal saving decisions. If there are no investment consequences of the shift, the net result is more exports, more imports, and higher $P / e P^{*}$. The effect on the current account is like that of a permanent rise in $Z$, and thus the $C A$ effects depend on $r$ and $\delta$. The rise in $P / e P^{*}$ is also likely to increase $I$. A rise in $P / e P^{*}$ decreases $P_{N} / P$, because $P_{N} / P=\left(P^{*}{ }_{N} / P^{*}\right)\left(P^{*} e / P\right)$ and $I$ is likely to rise as $P_{N} / P$ falls. The reduction in the relative price of foreign goods themselves may also stimulate investment if the foreign good is an investment good. If the investment response to the demand shift is sufficiently great, the effect of a permanent upward shift in the demand for exports is a first-period deficit, not a surplus! This brief discussion should indicate the danger of mechanically linking a country's current account balance to trend changes in the demand for its goods. A shift in demand away from a country's goods lowers its welfare by reducing $P / e P^{*}$ but does not necessarily cause 
a deficit. On the other hand, a temporary increase in export demand is likely to generate a surplus, for now the demand shift is akin to a temporary rise in $Z$, which was shown to raise $C A_{1}$.

A realistic model of the OPEC price increase would allow for many regions, each producing imperfect substitutes for the outputs of other regions, and each with different endowments of oil. Some of the implications of a change in $P_{N}$ that arise in this broader context can be discussed by drawing on the two-country model. An interesting comparison is between two countries whose residents have the same utility function and share the same technologies but have different natural endowments of $N$. A rise in real energy prices that is perceived as temporary causes relatively larger deficits in the resource-poor economy, $R P$. But for a permanent rise in prices, there is no reason for the $R P$ economy to run larger deficits than the resource-rich economy, $R R$. In general, the opposite should be the case. Because the oil price rise unambiguously causes a larger drop in lifetime income in the $R P$ economy, aggregate consumption will fall more in this economy than in the $R R$ economy. The $R P$ economy will have a larger rise in final good exports that will match the difference in oil imports. Its larger rise in exports will be accompanied by a fall in the relative price of its export good. Both economies will also have a drop in investment, but $I$ will probably decline more in the $R P$ economy because its larger terms-of-trade loss results in a larger reduction in the marginal product of capital. The differential investment performance, then, largely explains the differential $C A$ performance; deficits will be smaller in the $R P$ economy, where investment declines more.

\section{An Empirical Analysis of Current Account Flows}

The previous analysis helps account for the direction and magnitude of international capital flows in the 1970s. The oil price increases in 1973 and 1979 help explain the large OPEC surpluses in the 1970s, but they do not go far in accounting for the distribution of the corresponding deficits among oil-importing countries. Recall tables 1 through 5; LDC deficits are too large to be attributed to increased costs of oil imports, and within the LDCs and developed countries, dependence on oil imports is "perversely" related to the size of deficits. 
Popular explanations of the current account have failed to recognize the large shifts in the distribution of world investment in the 1970s. Theories of the current account that focus on oil flows or government deficits implicitly attribute current account movements to shifts in national saving rather than to domestic investment. This view is particularly inappropriate for OECD countries, where shifts in investment have typically dominated saving rate movements in explaining current account patterns. In fact, downward shifts in saving rates after 1973 are statistically correlated with current account surpluses, not deficits!

Within the LDCs, the great heterogeneity of economies leads to a large variation in key factors causing movements in the current account. The dominant determinants of current account movements in economies such as Argentina, Brazil, Korea, Mexico, Philippines, Taiwan, and Thailand - countries with diversified export bases plus growing manufacturing sectors-were shifts in investment rates after 1973. For LDCs with a high reliance on exports from primary-commodity sectors, transitory shifts in the terms of trade for exports were crucial for the current account. Thus, when copper prices collapsed in 1975, saving rates in Chile and Zambia (and to some extent, Peru) fell sharply. Because of their size and level of development, the pattern of the first group of countries dominates the LDC data examined below.

To understand the importance of these shocks, I have looked at the economies of a subset of LDCs and developed countries in the 1970s. The LDCs are the ten countries analyzed in Solomon's 1977 BPEA paper. ${ }^{15}$ This group includes most major middle- to high-income, nonEuropean developing countries, and overlaps with the OECD designation of "newly industrialising countries" (NICs). ${ }^{16}$ Solomon selected this list because it includes the top borrowers from external, private sources. The LDC current account deficits of the ten countries accounted for an average of 52 percent of the overall deficits of nonoil developing countries in 1974-76. The accumulated net debt of the ten countries in 1976 was 51 percent of overall net debt of LDCs for that year. Most of the countries have remained high borrowers since the 1977 study, with the stunning exception of Taiwan, whose external debt was fully paid with the

15. Robert Solomon, "A Perspective on the Debt of Developing Countries, $B P E A, 2: 1977$, pp. 479-501.

16. The non-European NICs are Brazil, Mexico, Hong Kong, Korea, and Singapore; the European NICs are Greece, Portugal, Spain, and Yugoslavia. 
large current account surpluses in 1976-78. I also selected, as developed countries, the fifteen OECD economies for which the data were adequate for the period under study.

Data on saving, investment, the current account, and the national debt are shown in tables 8 and 9. The investment rate is gross fixed capital formation, $I^{f}$, as a percent of GNP; for the LDCs the saving rate is defined as GNP plus transfers from abroad minus private and public consumption expenditure, as a percentage of GNP. For LDCs, saving, $S$, and $C A$ have been adjusted for the capital gains on the outstanding debt. Collecting the necessary data for this correction for the OECD economies proved too difficult, however. ${ }^{17}$ Note that $C A / G N P$ does not equal $S / G N P-I / G N P$ in tables 8 and 9 , as indicated by equation 4 , because $I / G N P$ in both tables excludes inventory accumulation.

A comparison of the two groups of countries shows, between the periods of 1965-73 and 1974-79, that $C A / G N P$ dropped considerably more in the aggregate for the LDCs than for the developed countries. This difference can be traced to a rise in $I / G N P$ that surpassed a rise or accompanied a decline in $S / G N P$ in the large LDCs; in most developed countries, both $I / G N P$ and $S / G N P$ fell, with the drop in saving rates exceeding the fall in $I / G N P$. The investment behavior within each group is fairly uniform. In eight of the ten LDCs, $I / G N P$ rose; $I / G N P$ fell in ten of the fifteen developed countries.

The last rows of tables 8 and 9 show aggregate measures of $I / G N P$, $S / G N P$, and $C A / G N P$ for the two groups. Compositional effects give rise to substantial differences between the experience of the typical country and the behavior of the aggregates. These effects are particularly striking for the OECD. Although ten developed economies, including the largest, experienced a decline in investment rates, the overall OECD investment rate is about constant. This is because the fast-growing countries in the OECD are also the high investment countries. Thus the $I / G N P$ of the high-investment countries receives greater weight each year in the overall ratio for the OECD. The country-by-country decline in $I / G N P$ and $S / G N P$ is largely concealed in the aggregate. A fixed-weight index for the fifteen countries would show sizable drops for $I / G N P$ and $S / G N P$.

17. The data on the LDC debt are collected and reported by the Organisation for Economic Co-operation and Development (OECD), while the net external investment positions of the OECD economies are reported by the countries themselves, if at all; it was difficult to obtain the necessary time series on a year-to-year basis. 
Table 8. Saving, Investment, the Current Account, and National Debt, Adjusted for Inflation, Selected LDCs, 1965-79a

Percent

\begin{tabular}{lrrrrrrrrr}
\hline $\begin{array}{c}\text { Country and } \\
\text { item }\end{array}$ & \multicolumn{2}{c}{ Average } & & & & & & \\
\cline { 2 - 3 } & $1965-73$ & $1974-79 \mathrm{~b}$ & 1974 & 1975 & 1976 & 1977 & 1978 & 1979 \\
\hline Argentina & & & & & & & & \\
$I / G N P$ & 19.8 & 21.2 & 20.6 & 21.8 & n.a. & n.a. & n.a. & n.a. \\
$S / G N P$ & 20.2 & 19.1 & 20.8 & 17.4 & n.a. & n.a. & n.a. & n.a. \\
$C A / G N P$ & -0.2 & -3.3 & -1.9 & -4.6 & n.a. & n.a. & n.a. & n.a. \\
$D / G N P$ & 4.8 & 8.1 & 5.2 & 11.0 & n.a. & n.a. & n.a. & n.a.
\end{tabular}

Brazil ${ }^{c}$

$\begin{array}{lrrrrrrrr}I / G N P & 22.6 & 23.4 & 24.2 & 25.5 & 24.0 & 22.4 & 22.2 & 21.9 \\ S / G N P & 23.2 & 21.0 & 25.8 & 21.0 & 20.5 & 20.8 & 19.8 & 18.1 \\ C A / G N P & -1.7 & -3.6 & -5.8 & -4.5 & -3.5 & -1.6 & -2.4 & -3.7 \\ D / G N P & 4.0 & 19.2 & 16.0 & 17.1 & 19.5 & 19.2 & 21.4 & 21.9\end{array}$

Chile

$\begin{array}{lrrrrrrrr}I / G N P & 13.8 & 10.1 & 12.3 & 10.2 & 8.9 & 9.1 & \text { n.a. } & \text { n.a. } \\ S / G N P & 13.3 & 8.3 & 14.9 & 2.8 & 8.4 & 7.3 & \text { n.a. } & \text { n.a. } \\ C A / G N P & -1.6 & -0.2 & 1.5 & -3.5 & 2.9 & -1.8 & \text { n.a. } & \text { n.a. } \\ D / G N P & 21.1 & 32.7 & 26.3 & 42.0 & 33.9 & 28.7 & \text { n.a. } & \text { n.a. }\end{array}$

Colombia

$\begin{array}{lrrrrrrrl}I / G N P & 19.7 & 19.2 & 19.4 & 18.9 & 18.4 & 18.9 & 20.4 & \text { n.a. } \\ S / G N P & 18.3 & 22.5 & 21.1 & 18.0 & 22.1 & 26.9 & 24.3 & \text { n.a. } \\ C A / G N P & -2.7 & 0.7 & -1.5 & 0.1 & 0.9 & 3.1 & 1.1 & \text { n.a. } \\ D / G N P & 14.6 & 17.7 & 18.3 & 18.7 & 20.0 & 16.0 & 15.4 & \text { n.a. }\end{array}$

$\begin{array}{lrrrrrrrr}\text { Mexico }^{\text {c }} & & & & & & & & \\ I / G N P & 19.5 & 22.6 & 21.5 & 22.7 & 22.3 & 20.5 & 22.8 & 25.7 \\ S / G N P & 18.6 & 22.5 & 23.2 & 20.6 & 21.1 & 21.8 & 23.3 & 25.0 \\ C A / G N P & -2.1 & -3.0 & -3.1 & -4.2 & -3.6 & -1.2 & -2.5 & -3.4 \\ D / G N P & 11.1 & 21.7 & 16.3 & 18.3 & 22.1 & 25.9 & 24.6 & 23.4\end{array}$

Peru

$\begin{array}{lrrrrrrrr}I / G N P & 12.7 & 15.4 & 15.1 & 17.3 & 16.7 & 14.6 & 14.0 & 14.5 \\ S / G N P & 15.9 & 15.0 & 14.3 & 10.8 & 11.9 & 10.9 & 18.1 & 23.8 \\ C A / G N P & 1.7 & -1.8 & -4.5 & -8.7 & -6.0 & -4.2 & 3.5 & 9.1 \\ D / G N P & 19.9 & 31.0 & 21.7 & 22.4 & 28.3 & 36.4 & 42.5 & 34.8\end{array}$

$\begin{array}{lrrrrrrrr}\text { Philippines } & & & & & & & & \\ I / G N P & 16.2 & 23.0 & 18.6 & 24.2 & 24.6 & 23.4 & 23.1 & 24.2 \\ S / G N P & 21.4 & 26.7 & 25.9 & 26.2 & 25.6 & 25.9 & 28.1 & 28.6 \\ C A / G N P & 0.3 & -2.4 & -0.8 & -4.9 & -5.1 & -2.6 & -0.1 & -0.7 \\ D / G N P & 9.8 & 18.4 & 14.2 & 17.2 & 21.8 & 20.3 & 18.7 & 18.2\end{array}$


Table 8 (continued)

\begin{tabular}{lrrrrrrrr}
\hline $\begin{array}{c}\text { Country and } \\
\text { item }\end{array}$ & \multicolumn{2}{c}{ Average } & & & & & & \\
\cline { 2 - 5 } & $1965-73$ & $1974-79 \mathrm{~b}$ & 1974 & 1975 & 1976 & 1977 & 1978 & 1979 \\
\hline South Korea & & & & & & & & \\
$\quad I / G N P$ & 23.9 & 27.1 & 25.2 & 25.6 & 23.5 & 25.7 & 30.3 & 32.1 \\
$S / G N P$ & 19.5 & 25.3 & 22.7 & 20.9 & 25.0 & 26.5 & 28.2 & 28.3 \\
$C A / G N P$ & -6.4 & -4.3 & -8.0 & -8.0 & -0.2 & -0.6 & -2.6 & -6.7 \\
$D / G N P$ & 2.4 & 23.7 & 18.1 & 28.1 & 25.9 & 24.3 & 21.2 & 24.9 \\
Taiwan & & & & & & & & \\
$I / G N P$ & 23.2 & 27.9 & 28.8 & 30.1 & 28.3 & 26.8 & 25.6 & n.a. \\
$S / G N P$ & 28.1 & 29.8 & 30.4 & 26.0 & 30.2 & 30.2 & 32.5 & n.a. \\
$C A / G N P$ & 2.4 & 0.6 & -7.9 & -3.1 & 2.6 & 5.1 & 6.1 & n.a. \\
$D / G N P$ & 18.8 & 9.4 & 13.4 & 16.1 & 13.7 & 5.8 & -1.9 & n.a. \\
& & & & & & & & \\
Thailand & & & & & & & & \\
$I / G N P$ & 22.8 & 23.6 & 21.8 & 22.2 & 21.8 & 25.2 & 24.6 & 26.2 \\
$S / G N P$ & 22.1 & 23.8 & 26.5 & 23.4 & 22.1 & 22.9 & 24.6 & 23.6 \\
$C A / G N P$ & -2.5 & -2.0 & 1.6 & -2.1 & -1.3 & -3.3 & -2.1 & -4.5 \\
$D / G N P$ & 3.2 & 8.5 & 6.3 & 6.3 & 7.0 & 8.7 & 10.1 & 12.6
\end{tabular}

Total,

excluding

Argentina

$\begin{array}{lrrrrrrrr}\text { I/GNP } & 20.4 & 22.6 & 22.3 & 22.7 & 22.7 & 21.8 & \text { n.a. } & \text { n.a. } \\ S / G N P & 20.6 & 21.9 & 24.0 & 20.4 & 21.2 & 21.9 & \text { n.a. } & \text { n.a. } \\ C A / G N P & -1.8 & -3.1 & -4.2 & -4.5 & -2.6 & -1.1 & \text { n.a. } & \text { n.a. } \\ D / G N P & 8.5 & 19.0 & 16.3 & 18.6 & 20.7 & 20.6 & \text { n.a. } & \text { n.a. }\end{array}$

Sources: Calculations by the author. Data for investment, saving, GNP, and current account-International Monetary Fund, International Financial Statistics; Net debt-Organisation for Economic Cooperation and Development, Development Cooperation: 1977 Review (Paris: OECD, 1977); saving rate for Brazil and Mexico, without adjusting for inflation-Edmar Bacha and Carlos Diaz-Alejandro, "Financial Markets: A View from the Semi-Periphery," paper presented at the International Seminar on External Financial Relations and Their Impact on the Latin American Economies (Santiago, Chile, March 1981), table 12, p. 53 .

n.a. Not available.

a. $I / G N P$ is calculated as fixed investment, $I^{f}$, divided by $G N P ; S / G N P$ is $(G N P+R-C-G) / G N P$, where $C$ is consumption; and $C A / G N P$ is $\left(G N P+R-C-I^{f}-I^{s}-G\right) / G N P$, where $I^{s}$ is inventory investment. GNP is corrected for the inflation bias by adding to it the capital gains on outstanding net debt, where net debt is defined as gross debt minus foreign exchange reserves. To obtain net debt a benchmark is used from the OECD Development Cooperation: 1977 Review, which gives gross debt at the end of 1975. We subtract from this the 1975 year-end foreign exchange reserves of the International Monetary Fund. The time series is derived by applying the perpetual inventory method to this benchmark. The annual current account deficits minus net foreign direct investment inflows are cumulated from the point at which $1975=0$, and the series is scaled up by the 1975 net debt. The result is an end-of-year net debt series, $D_{t}^{N}$. To obtain average debt over a year, the expression $0.5\left(D_{t}^{N}+D_{t-1}^{N}\right)$ is used. This a verage net debt is multiplied by the annual U.S. inflation rate, measured as the fourth-quarter-over-fourth-quarter change in the GNP deflator. The result is added to GNP.

The totals for the LDCs in the last three rows are calculated as $(\Sigma I) /(\Sigma G N P),(\Sigma S) /(\Sigma G N P),(\Sigma C A) /$ $(\Sigma G N P)$, where the summations are over the nine countries, and $I, S, C A$, and $G N P$ are converted to U.S. dollars, using the annual average exchange rate.

b. The average is taken over all available years through 1979 .

c. An alternative measure of the saving rate for Brazil and Mexico, not adjusted for inflation, is given in Bacha and Diaz-Alejandro, "Financial Markets: A View from the Semi-Periphery," table 12, p. 53. The rates for Brazil are 21.1 for 1960-64, 21.8 for 1965-69, 23.8 for 1970-74, and 22.3 for 1975-78; the rates for Mexico are 17.3 for 1960-64, 19.4 for 1965-69, 19.1 for 1970-74, and 21.3 for 1975-77. 
Table 9. Saving, Investment, and the Current Account, Developed Countries, 1965-79a Percent

\begin{tabular}{|c|c|c|c|c|c|c|c|c|}
\hline \multirow{2}{*}{$\begin{array}{c}\text { Country and } \\
\text { item }^{\mathrm{b}}\end{array}$} & \multicolumn{2}{|c|}{ Average } & \multirow[b]{2}{*}{1974} & \multirow[b]{2}{*}{1975} & \multirow[b]{2}{*}{1976} & \multirow[b]{2}{*}{1977} & \multirow[b]{2}{*}{1978} & \multirow[b]{2}{*}{1979} \\
\hline & $1965-73$ & 1974-79 & & & & & & \\
\hline \multicolumn{9}{|l|}{ United States } \\
\hline$I / G N P$ & 17.8 & 17.1 & 17.5 & 16.1 & 16.2 & 17.0 & 17.8 & 17.7 \\
\hline$S / G N P$ & 18.7 & 17.8 & 18.7 & 16.8 & 17.2 & 17.4 & 18.1 & 18.4 \\
\hline$C A / G N P$ & 0.0 & 0.0 & 0.1 & 1.2 & 0.3 & -0.7 & -0.7 & 0.0 \\
\hline$I^{m} / I$ & n.a. & n.a. & 1.4 & 1.7 & 1.8 & 1.9 & n.a. & n.a. \\
\hline
\end{tabular}

United

Kingdom

$\begin{array}{lrrrrrrrr}I / G N P & 18.5 & 18.6 & 20.0 & 19.4 & 18.8 & 18.0 & 18.0 & 17.6 \\ S / G N P & 19.8 & 18.2 & 17.5 & 16.4 & 18.6 & 19.1 & 19.1 & 18.2 \\ C A / G N P & 0.4 & -1.2 & -4.0 & -1.6 & -0.9 & -0.1 & 0.4 & -0.9 \\ I^{m} / I & \text { n.a. } & \text { n.a. } & 4.4 & 7.6 & 10.1 & 9.8 & 9.3 & \text { n.a. }\end{array}$

Austria

$\begin{array}{lrrrrrrrr}I / G N P & 27.2 & 26.3 & 28.2 & 26.8 & 26.1 & 26.4 & 25.3 & 25.2 \\ S / G N P & 28.6 & 24.7 & 29.2 & 25.4 & 23.7 & 21.5 & 23.3 & 24.9 \\ C A / G N P & -0.5 & -2.9 & -1.4 & -0.9 & -3.7 & -6.3 & -2.5 & -2.6\end{array}$

Belgium

$\begin{array}{lrrrrrrrr}I / G N P & 21.3 & 21.4 & 22.2 & 22.0 & 21.5 & 21.2 & 21.0 & 20.6 \\ S / G N P & 25.0 & 21.5 & 25.3 & 22.2 & 21.9 & 20.7 & 20.2 & 18.7 \\ C A / G N P & 2.5 & -0.4 & 0.9 & 0.8 & 0.0 & -0.8 & -1.0 & -2.3 \\ I^{m} / I & \text { n.a. } & \text { n.a. } & 0.5 & 0.4 & 0.3 & 0.3 & 0.4 & \text { n.a. }\end{array}$

Denmark

$\begin{array}{lrrrrrrrr}I / G N P & 24.6 & 23.0 & 24.6 & 21.6 & 23.9 & 23.0 & 22.8 & 22.2 \\ S / G N P & 23.3 & 20.3 & 22.7 & 19.9 & 20.2 & 20.1 & 20.5 & 18.3 \\ C A / G N P & -2.1 & -3.3 & -2.9 & -1.4 & -4.6 & -3.7 & -2.7 & -4.5\end{array}$

France

$\begin{array}{lrrrrrrrr}I / G N P & 23.4 & 22.6 & 24.2 & 23.2 & 23.2 & 22.2 & 21.4 & 21.2 \\ S / G N P & 25.3 & 23.1 & 24.3 & 23.0 & 22.7 & 22.5 & 22.8 & 23.0 \\ C A / G N P & -0.3 & -0.6 & -2.3 & 0.0 & -1.7 & -0.8 & 0.8 & 0.2\end{array}$

Germany

$\begin{array}{lrrrrrrrr}I / G N P & 24.7 & 21.3 & 21.9 & 20.7 & 20.6 & 20.7 & 21.3 & 22.6 \\ S / G N P & 27.1 & 23.2 & 25.2 & 21.6 & 22.7 & 22.7 & 23.4 & 24.0 \\ C A / G N P & 1.0 & 1.0 & 2.7 & 1.0 & 0.9 & 0.8 & 1.4 & -0.7 \\ I^{m} / I & \text { n.a. } & \text { n.a. } & 0.6 & 1.0 & 1.0 & \text { n.a. } & \text { n.a. } & \text { n.a. }\end{array}$

Italy

$\begin{array}{lllllllll}I / G N P & 20.8 & 20.0 & 22.4 & 20.6 & 20.1 & 19.6 & 18.7 & 18.7\end{array}$

$\begin{array}{lllllllll}S / G N P & 23.4 & 22.1 & 21.9 & 20.1 & 22.2 & 22.6 & 22.4 & 23.2\end{array}$

$\begin{array}{lllllllll}C A / G N P & 1.4 & -0.2 & -4.7 & -0.3 & -1.5 & 1.1 & 2.4 & 1.6\end{array}$

Norway

$\begin{array}{lrrrrrrrr}I / G N P & 27.7 & 33.7 & 31.0 & 34.6 & 37.0 & 38.0 & 32.9 & 28.4 \\ S / G N P & 27.7 & 26.2 & 29.3 & 27.0 & 25.7 & 22.9 & 24.7 & 27.8 \\ C A / G N P & -1.0 & -8.0 & -4.8 & -8.6 & -12.1 & -14.3 & -5.5 & -2.3 \\ I^{m} / I & \text { n.a. } & \text { n.a. } & 8.6 & 8.6 & 11.2 & 16.4 & 12.4 & \text { n.a. }\end{array}$


Table 9 (continued)

\begin{tabular}{|c|c|c|c|c|c|c|c|c|}
\hline \multirow{2}{*}{$\begin{array}{c}\text { Country and } \\
\text { item }^{\mathrm{b}}\end{array}$} & \multicolumn{2}{|c|}{ Average } & \multirow[b]{2}{*}{1974} & \multirow[b]{2}{*}{1975} & \multirow[b]{2}{*}{1976} & \multirow[b]{2}{*}{1977} & \multirow[b]{2}{*}{1978} & \multirow[b]{2}{*}{1979} \\
\hline & $1965-73$ & $1974-79$ & & & & & & \\
\hline \multicolumn{9}{|l|}{ Sweden } \\
\hline$I / G N P$ & 22.3 & 20.7 & 21.9 & 21.0 & 20.9 & 20.9 & 19.5 & 20.0 \\
\hline$S / G N P$ & 23.4 & 20.0 & 22.8 & 24.0 & 21.1 & 17.2 & 17.6 & 17.5 \\
\hline$C A / G N P$ & 0.3 & -1.6 & -1.3 & -0.5 & -2.2 & -2.7 & -0.3 & -2.7 \\
\hline$I^{m} / I$ & n.a. & n.a. & 0.9 & 0.9 & 1.0 & 1.0 & 0.6 & n.a. \\
\hline \multicolumn{9}{|l|}{ Canada } \\
\hline$I / G N P$ & 21.8 & 23.3 & 23.2 & 24.2 & 23.5 & 23.1 & 22.7 & 22.9 \\
\hline$S / G N P$ & 22.7 & 22.1 & 24.6 & 21.2 & 22.3 & 21.2 & 20.6 & 22.7 \\
\hline$C A / G N P$ & 0.0 & -2.0 & -1.0 & -2.9 & -2.0 & -2.1 & -2.2 & -2.0 \\
\hline$I^{m} / I$ & n.a. & n.a. & 5.8 & 6.4 & 7.6 & 8.0 & 7.2 & n.a. \\
\hline \multicolumn{9}{|l|}{ Japan } \\
\hline$I / G N P$ & 34.9 & 31.6 & 34.8 & 32.2 & 31.0 & 30.1 & 30.2 & 31.6 \\
\hline$S / G N P$ & 38.4 & 32.9 & 36.4 & 32.5 & 32.3 & 32.3 & 32.5 & 31.8 \\
\hline$C A / G N P$ & 1.3 & 0.3 & -1.0 & -0.1 & 0.7 & 1.6 & 1.7 & -0.9 \\
\hline \multicolumn{9}{|l|}{ Finland } \\
\hline$I / G N P$ & 26.3 & 27.4 & 30.1 & 31.5 & 28.1 & 27.1 & 23.9 & 23.7 \\
\hline$S / G N P$ & 27.5 & 25.3 & 30.1 & 25.6 & 23.8 & 23.4 & 23.4 & 25.1 \\
\hline$C A / G N P$ & -1.2 & -2.7 & -5.3 & -7.9 & -3.9 & -0.5 & 1.9 & -0.5 \\
\hline$I^{m} / I$ & n.a. & n.a. & 0.6 & 0.6 & 0.5 & 0.3 & n.a. & n.a. \\
\hline \multicolumn{9}{|l|}{ Australia } \\
\hline$I / G N P$ & 25.8 & 23.0 & 23.0 & 23.4 & 23.2 & 23.0 & 22.9 & 22.3 \\
\hline$S / G N P$ & 25.0 & 21.8 & 24.0 & 22.3 & 22.2 & 21.0 & 19.5 & 22.1 \\
\hline$C A / G N P$ & -1.7 & -2.3 & -3.3 & -0.7 & -1.6 & -2.8 & -3.6 & -1.7 \\
\hline \multicolumn{9}{|l|}{ Netherlands } \\
\hline$I / G N P$ & 24.8 & 21.0 & 21.6 & 20.8 & 19.2 & 20.9 & 21.5 & 21.7 \\
\hline$S / G N P$ & 27.3 & 23.0 & 27.6 & 23.0 & 23.5 & 22.2 & 21.3 & 20.6 \\
\hline$C A / G N P$ & 0.9 & 1.1 & 3.1 & 2.4 & 3.0 & 0.6 & -1.1 & -1.5 \\
\hline$I^{m} / I$ & n.a. & n.a. & 0.1 & 0.1 & 0.2 & 0.3 & 0.2 & n.a. \\
\hline \multicolumn{9}{|l|}{ Total } \\
\hline$I / G N P$ & 21.6 & 21.3 & 22.2 & 21.0 & 20.8 & 20.9 & 21.4 & 21.5 \\
\hline$S / G N P$ & 23.1 & 22.0 & 23.3 & 21.0 & 21.4 & 21.5 & 22.2 & 22.2 \\
\hline$C A / G N P$ & 0.3 & -0.2 & -0.6 & 0.2 & -0.3 & -0.4 & 0.1 & -0.5 \\
\hline
\end{tabular}

Sources: Current account balance-Organisation for Economic Co-operation and Development, Main Economic Indicators; GNP and fixed capital formation for all countries except the United States-International Monetary Fund, International Financial Statistics; U.S. fixed capital formation and the fixed capital formation in the mining and quarrying sector-OECD, National Accounts of OECD Countries, 1950-1978 (Paris: OECD, 1980) and recent supplements.

n.a. Not available.

a. For all countries national saving is defined as the current account, $C A$, plus total investment, where total investment is the sum of gross fixed capital formation $I^{f}$ and inventory investment. Gross fixed capital formation is expressed as a proportion of $G N P$ and denoted by $I / G N P$; and $I^{m}$ is fixed capital formation in the mining and quarrying sector.

The totals in the last three rows are calculated as $(\Sigma I) /(\Sigma G N P),(\Sigma S) /(\Sigma G N P),(\Sigma C A) /(\Sigma G N P)$, where the summations are over the fifteen countries, and $I, S, C A, G N P$ are converted to U.S. dollars, using the annual average exchange rate.

b. No data are available on $I^{m} / I$ for Austria, Denmark, France, Italy, Japan, Australia, and the total average. 


\section{WORLD INVESTMENT SHIFTS}

The investment performance of this period represents a shift in the locus of new investment in the world economy. The third row of table 10 shows the share of gross fixed capital formation undertaken in the ten LDCs as a fraction of the total investment of the twenty-five countries. The ratio rises significantly after 1973 , after climbing slowly through the 1960s and early 1970s. The LDC share of GNP also rose but not enough to account for the rise in investment share.

To a significant but variable extent, the sharp rise in investment was encouraged by official development programs. The literature on these programs is extensive, including overview discussions presented in reports by OECD, UNCTAD, and Brookings. ${ }^{18}$ It is widely believed that there has been a rise in receptiveness to foreign investment, political stability, and domestic economic reform in many of these economies, with a resulting rise in the profitability of physical investment. The OECD report describes the successes of the newly industrialising countries in attracting foreign direct investment in the 1970s, with ten of those countries, led by Mexico and Brazil, now accounting for 34 percent of the total stock of private direct foreign investment by developed countries in LDCs. The heralded policy shift from a strategy of import substitution to export promotion in many of the economies has been accompanied by a liberalization of foreign capital inflows.

In addition to the favorable developments within the LDCs, a significant worsening of investment opportunities in the developed economies

18. See the Organisation for Economic Co-operation and Development, The Impact of the Newly Industrialising Countries on Production and Trade in Manufactures (Paris: OECD, 1979); United Nations Development Program/United Nations Conference on Trade and Development, "The Balance of Payments Adjustment Process in Developing Countries: Report to the Group of Twenty-Four," Project Int/75/015, January 2, 1979; and William R. Cline and Sidney Weintraub, Economic Stabilization in Developing Countries (Brookings Institution, 1981). From the International Seminar on External Financial Relations and their Impact on the Latin American Economies (Santiago, Chile, March 1981), see Albert Fishlow, "Latin American External Debt: Problem or Solution?" Pedro Malan, "Financial Integration with the World Economy: The Brazilian Case"; Roberto Frenkel, "Financial Liberalization and Capital Flows: The Case of Argentina"; and Ricardo Ffrench-Davis and José Pablo Arellano, "Financia Liberalization and Foreign Debt: The Chilean Experience, 1978-80." 


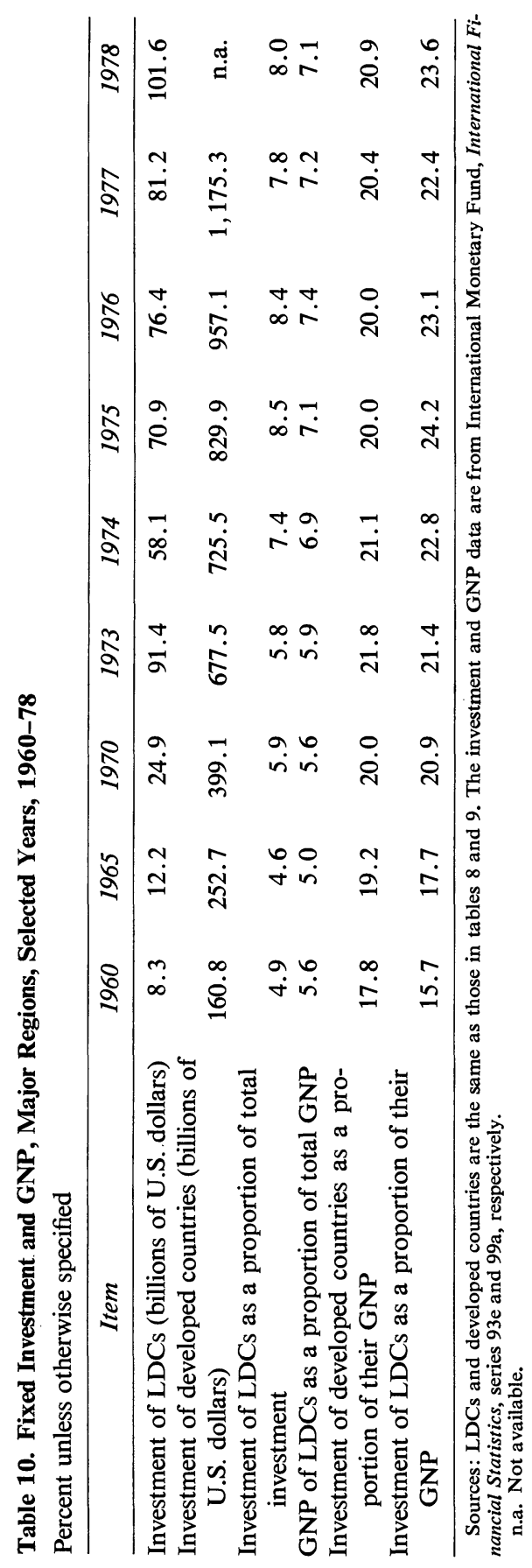


during the 1970s contributed to a reduction in world real interest rates and to ready access to capital for the developing countries. As a recent study by the International Monetary Fund correctly points out: "The 1974-75 recession reduced lending opportunities in the industrial countries, so that banks were willing to maintain their lending to the developing world, and at the same time real interest rates were low enough to keep debt service requirements from becoming too onerous." ${ }_{19}$

Several developments contributed to the weakening of investment by developed economies. First, the post-World War II investment boom in many OECD economies had reached steeply diminishing marginal returns in the early 1970s. The technological gap between most European countries and the United States had been substantially closed, while the growth in their effective labor supply slowed as the process of transferring labor from surplus sectors was completed. Developments in Japanese investment have been described in these same terms by many observers. ${ }^{20}$

Second, a sharp squeeze in profits (exceeding the effects of capital deepening) apparently affected most of the OECD economies in the 1970s. As Perry, Gordon, and I have documented in previous $B P E A$ studies, real wage growth accelerated sharply in the early 1970s in most countries except the United States, and did not moderate greatly in the

19. International Monetary Fund, "International Capital Markets: Recent Developments and Short-Term Prospects" Occasional Paper 1 (IMF, September 1980), p. 5. Similarly, in the OECD study, The Impact of the Newly Industrialising Countries, it is noted: "The abundance of investable funds created by the OPEC surplus and by depressed private demand for credit in the OECD area facilitated the financing of productive investment in promising countries outside the OECD, notably the NICs and the Eastern Bloc."

20. See, for example, OECD Economic Survey: Japan (Paris: OECD, 1977), p. 27, in which it is stated:

Looking at medium-term productivity trends, it may be worth noting that a structural shift seems also to have occurred since the beginning of the seventies. Up to the end of the sixties, the efficiency of capital remained exceptionally high, despite the very rapid rate of capital accumulation. In recent years, however, the productivity of private capital has declined considerably, reflecting important structural changes in the composition of investment. ... As noted, in recent years the technological gap between Japan and other major industrial countries has been largely closed, which considerably reduces the scope for importing ready made foreign know-how. The substantial slowdown in growth of the private capital stock, its changing composition and the parallel decline of productivity have resulted in a marked deceleration of the growth of productive capacity, all the more so, since deep changes in the structure of relative prices entailed by the sharp rise in oil prices have contributed to increase the obsolescence of certain equipment. 
first years following the energy price increases in 1973-74. ${ }^{21}$ The result was a rise in labor's share of income, $w L / G N P$, and a fall in the beforetax rate of return to corporate capital in many economies.

Table 11 summarizes these developments in labor's share and compares them with developments in five LDCs for which UN data are available. The consistent rise in labor's share in almost all OECD economies is apparently unmatched in LDCs. For every OECD economy the share of labor for the most recent year included is greater than the 1969 value. The opposite is true for the LDCs; only two of the five show an increase during the same period.

A third factor in the investment shift is the boom in raw materials investment generally, which has been occurring largely in the nonoil LDCs. The post 1972-74 rise in raw materials investments was spurred by the intense desire of many corporations and governments of developed countries to hedge against future embargoes of primary products following the 1973 oil embargo. It is extremely difficult to obtain aggregate data for sectoral capital formation in the LDCs to measure this effect. It should be noted, however, that the majority of U.S. foreign direct investment in this period was not in the mining or petroleum sectors, but in manufacturing. In 1972, 50 percent of U.S. direct investment in the LDCs was in petroleum and mining, and 26 percent was in manufacturing. From 1972 to 1979 , the petroleum and mining assets fell by 23 percent (in current dollars), due in part to expropriation, while the book value of U.S. manufacturing assets in LDCs rose by 143 percent. Thus in 1979 the mining and petroleum interests accounted for 20 percent of U.S. investments in developing countries, and manufacturing for 34 percent. ${ }^{22}$

In many developing economies the rise in investment rates was matched by higher saving rates. Such a correlation is not implied by models with perfect capital mobility. Restrictions on capital flows, however, cause a rise in home interest rates relative to world rates and a partial financing of new investment from domestic saving rather than from international capital markets. One can speculate that rising saving

21. See George L. Perry, "Determinants of Wage Inflation around the World," $B P E A$, 2:1975, pp. 403-35; Robert J. Gordon, "World Inflation and Monetary Accommodation in Eight Countries," BPEA, 2:1977, pp. 409-68; and Jeffrey D. Sachs, "Wages, Profits, and Macroeconomic Adjustment: A Comparative Study," BPEA, 2:1979, pp. 269-319.

22. See Survey of Current Business, vol. 53 (September 1973), pp. 26-27, and vol. 60 (August 1980), p. 27. 
Table 11. Share of Labor in GNP, Developed Countries and Selected LDCs, 1965-78 Percent

\begin{tabular}{|c|c|c|c|c|c|c|c|c|c|}
\hline \multirow{2}{*}{$\begin{array}{l}\text { LDCs and } \\
\text { developed } \\
\text { countries }\end{array}$} & \multicolumn{2}{|c|}{ Average } & \multirow[b]{2}{*}{1969} & \multirow[b]{2}{*}{1973} & \multirow[b]{2}{*}{1974} & \multirow[b]{2}{*}{1975} & \multirow[b]{2}{*}{1976} & \multirow[b]{2}{*}{1977} & \multirow[b]{2}{*}{1978} \\
\hline & $1965-73$ & $1974-78$ & & & & & & & \\
\hline \multicolumn{10}{|l|}{ LDCs } \\
\hline Brazil & 38 & $38^{\mathrm{b}}$ & $37^{\mathrm{c}}$ & 38 & 37 & 39 & n.a. & n.a. & n.a. \\
\hline Colombia & 38 & 34 & 38 & 35 & 34 & 35 & 33 & 33 & 34 \\
\hline Korea & 32 & 33 & 32 & 30 & 30 & 31 & 32 & 34 & 37 \\
\hline Mexico & 37 & 38 & 34 & 37 & 37 & 38 & 41 & 38 & 38 \\
\hline Thailand & 25 & 24 & 25 & 23 & 23 & 24 & 24 & 24 & 24 \\
\hline \multicolumn{10}{|l|}{ Developed countries } \\
\hline United States & 61 & 62 & 61 & 62 & 62 & 61 & 61 & 61 & 62 \\
\hline United Kingdom & 59 & 62 & 56 & 59 & 63 & 65 & 62 & 60 & 60 \\
\hline Austria & 49 & 54 & 49 & 51 & 52 & 54 & 54 & 55 & 56 \\
\hline Belgium & 50 & 57 & 49 & 53 & 55 & 57 & 57 & 58 & 58 \\
\hline Denmark & 51 & 54 & 50 & 51 & 55 & 56 & 54 & 54 & 54 \\
\hline France & 48 & 54 & 48 & 50 & 52 & 54 & 54 & 54 & 54 \\
\hline Germany & 53 & 56 & 51 & 55 & 57 & 56 & 56 & 56 & 55 \\
\hline Italy & 51 & 56 & 51 & 53 & 53 & 57 & 56 & 57 & 56 \\
\hline Netherlands & 56 & 59 & 55 & 57 & 59 & 61 & 59 & 59 & 59 \\
\hline Norway & 54 & 59 & 55 & 61 & 57 & 59 & 60 & 61 & 60 \\
\hline Canada & 55 & 57 & 55 & 55 & 55 & 57 & 57 & 58 & 57 \\
\hline Japan & 44 & 53 & 42 & 48 & 50 & 53 & 54 & 54 & 53 \\
\hline Finland & 50 & $54^{\mathrm{d}}$ & 50 & 51 & 51 & 54 & 56 & 55 & n.a. \\
\hline Australia & 57 & 61 & 56 & 60 & 65 & 62 & 60 & 60 & 60 \\
\hline Sweden & 60 & 66 & 60 & 61 & 62 & 64 & 68 & 71 & 70 \\
\hline
\end{tabular}

Sources: Data for the LDCs are from the United Nations, National Income Account Statistics, various years; for the developed countries, from the Organisation for Economic Co-operation and Development, National Accounts of OECD Countries, 1950-1978 (Paris: OECD, 1980).

n.a. Not available.

a. Calculated as labor compensation divided by total domestic factor incomes.

b. For 1974-75.

c. For 1970.

d. For 1974-77.

rates in the LDCs reflect in part the rising profitability of investment. Bacha and Diaz-Alejandro point to the role of liberalization of the domestic financial sector as a key to the rising saving rate. ${ }^{23}$ Whatever the explanation, the greater LDC investment cannot be due solely to an exogenous rise in domestic saving, because under almost any assumptions

23. See Edmar Bacha and Carlos Diaz-Alejandro, "Financial Markets: A View from the Semi-Periphery," paper presented at the International Seminar on External Financial Relations (Santiago, March 1981), pp. 51-57. One key reform was the introduction of indexed bonds as vehicles for domestic saving in some countries. 
an exogenous shift in saving would improve rather than worsen the current account.

Chile, the country with the sharpest drop in saving rates in the sample, is an exporter of primary commodities, particularly copper. Copper prices showed a boom in 1973 and then went into a precipitous decline. The price of Chilean copper exports relative to the U.S. export unit value index fell by half between 1973 and 1975. ${ }^{24}$ Assuming that the decline in copper prices was perceived as temporary, the model would predict a fall in the national saving rate matched by current account deficits, as is observed.

\section{THE LDC "DEBT PROBLEM"}

The manageability of the LDC debt has been the subject of a large literature in recent years. ${ }^{25}$ If my analysis is correct, much of the growth in LDC debt reflects increased investment and should not pose a problem of repayment. The major borrowers have accumulated debt in the context of rising or stable, but not falling, saving rates. This is particularly true for Brazil and Mexico, which together account for about 40 percent of the net bank liabilities of the LDCs and about 25 percent of total debt of the LDCs. ${ }^{26}$ The growth in debt might be a cause for concern if borrowing reflected an attempt to maintain consumption at unsustainable levels after the oil price increases. In that case, the debt would presage a fall in consumption that might prove to be politically or economically untenable and result in default. In fact, the current account reflects rising

24. See International Monetary Fund, International Financial Statistics, vol. 34 (February 1981), series 76cd and 74, pp. 110 and 408, respectively.

25. Among the many studies on this topic, see International Monetary Fund, "International Capital Markets"; many articles in World Development, vol. 7 (February 1979), including Ariel Buira Seira, "The World Economy, External Debt and Prospects for Development Financing," pp. 125-33, and Miguel S. Wionczek, "The LDC External Debt and the Euromarkets: The Impressive Record and the Uncertain Future," pp. 175-87; "Access of Developing Countries to International Financial Markets," in OECD, Financial Market Trends, vol. 13 (February 1980), pp. 91-108; M. S. Mendelsohn, Money on the Move (McGraw-Hill, 1980), particularly chaps. 17-20; and Bacha and Diaz-Alejandro, "Financial Markets"; and OECD, "External Indebtedness of Developing Countries: Present Situation and Future Prospects," 1979.

26. For bank net claims, see International Monetary Fund, "International Capital Markets," p. 9; for total disbursed debt, see OECD, Development Cooperation, 1980 (Paris: OECD, 1980), p. 221. 
Table 12. Average Spreads of External Borrowing Costs over London Inter-Bank Offered Rate, LIBOR, 1974-79

Percentage points

\begin{tabular}{lcccccc}
\hline \multicolumn{1}{c}{ Item } & 1974 & 1975 & 1976 & 1977 & 1978 & 1979 \\
\hline $\begin{array}{l}\text { All LDCs } \\
\text { Typical industrial country }\end{array}$ & 1.13 & 1.68 & 1.72 & 1.55 & 1.20 & 0.87 \\
$\quad$ (France) & 0.58 & 1.42 & 1.09 & 0.92 & 0.63 & 0.36 \\
$\begin{array}{l}\text { Difference } \\
\begin{array}{l}\text { LIBOR rate (percent } \\
\quad \text { per year) }\end{array}\end{array}$ & 0.55 & 0.27 & 0.63 & 0.63 & 0.57 & 0.51 \\
$\begin{array}{l}\text { Addendum } \\
\quad \text { Brazil }\end{array}$ & 11.32 & 7.74 & 6.26 & 6.54 & 9.48 & 12.12 \\
\hline
\end{tabular}

Source: All data except for that on Brazil are from World Bank, World Development Report, 1980, table 3.5, p. 27. The Brazilian data are cited in Albert Fishlow, "Latin American External Debt: Problem or Solution?" paper presented at the International Seminar on External Financial Relations and Their Impact on the Latin American Economies (Santiago, Chile, March 1981), table 2, p. 10.

a. The 1980 value is 1.75 .

investment rates in excess of rising or stable saving rates. As long as the investment projects undertaken have a positive present value at the borrowing rate of interest, the investing country should experience a rising consumption path over time.

Econometric evidence supports the view that higher investment rates reduce the likelihood of default for given levels of total debt. Kharas also reports econometric evidence that default probabilities have been a strongly declining function of $I / G N P$ for a large sample of countries in recent years. ${ }^{27}$ His evidence suggests that the strong investment performance of the large borrowers should help to explain why interest rate premiums have not risen for syndicated Euromarket loans to LDCs, despite the huge increases in LDC debt. Table 12 documents that the spread-the differential between Euromarket borrowing rates and the London Interbank Offered Rate (LIBOR) - has narrowed sharply since 1975 and 1976 . The movements in the spread hardly seem to characterize a market paralyzed by the fear of default and excessive exposure.

As a further check on the role of high investment rates in facilitating capital flows, I fit a cross-section regression of the average 1979 interest differential for thirty LDCs. The interest differential was regressed

27. Homi J. Kharas, "Optimal Debt Accumulation by Less Developed Countries-Theory and Practice" (Ph.D. dissertation, Harvard University, June 1980). 
on $(C A / G N P)_{78},(I / G N P)_{78},(D / G N P)_{78}$, and income per capita, $(G N P / L)_{78}$, as shown below. For given $C A / G N P$, increases in $I / G N P$ systematically reduce the spread: ${ }^{28}$

$$
\begin{aligned}
(i-L I B O R)_{79}= & 1.35-1.83(I / G N P)_{78}-2.49(C A / G N P)_{78}, \\
& (6.3)(-2.0) \quad(-2.3) \\
\bar{R}^{2}= & 0.16 ; \text { standard error }=0.29 .
\end{aligned}
$$

or

$$
\begin{aligned}
\left(i-L^{\prime} I B O R\right)_{79}= & 1.38-1.89(I / G N P)_{78}-3.17(C A / G N P)_{78} \\
& (5.7)(-2.2) \quad-(3.2) \\
& -0.009(G N P / L)_{78}+0.0008(D / G N P)_{78} \\
& (-1.4) \\
\bar{R}^{2}= & 0.35 ; \text { standard error }=0.26 .
\end{aligned}
$$

Additional evidence of the importance of investment to credit worthiness is the fact that most of the major reschedulings in recent years have occurred after a rise in current account deficits following a sharp drop in $S / G N P$, and almost never following a rise in $I / G N P$. Turkey appears to be the significant exception to this pattern among the six countries shown in table 13. (In the case of Peru, the debt renegotiation began in 1976 and 1977 , when $S / G N P$ was very low; it was concluded in 1978 , after $S / G N P$ had substantially recovered.) One can surmise that creditors pull back from a routine rollover of debt when the borrowing appears inconsistent with a reasonable path of future consumption, as is the case when heavy borrowing reflects a drop in domestic saving rates. Indeed, reschedulings are frequently linked to programs of the International Monetary Fund that call for increased saving and investment rates. ${ }^{29}$

On the pessimistic side, there may be financial difficulty for many LDCs if the high real interest rates of 1981 continue. This is a particularly serious problem because most bank loans to LDCs for long-term investment projects have a provision that adjusts interest costs on outstanding debt at fixed intervals to a predetermined spread over LIBOR. ${ }^{30}$

28. The data on spreads for 1979 are from Euromoney (February 1980), pp. 40-48. The regressions included the subset of the listed LDCs for which public borrowing exceeded $\$ 100$ million in 1979 . In this regression $C A$ is exclusive of official transfers. The numbers in parentheses are $t$-statistics.

29. I am indebted to Richard Cooper for this point.

30. For more details see Mendelsohn, Money on the Move, pp. 71-78. 
Table 13. The Current Account, Saving, and Investment in Countries with a Debt Rescheduling in 1974-78

Percent

\begin{tabular}{|c|c|c|c|c|c|c|c|}
\hline $\begin{array}{c}\text { Country and } \\
\text { item }\end{array}$ & $\begin{array}{l}\text { Average, } \\
1970-73\end{array}$ & 1974 & 1975 & 1976 & 1977 & 1978 & $\begin{array}{l}\text { Year of } \\
\text { debt } \\
\text { resched- } \\
\text { uling }\end{array}$ \\
\hline \multicolumn{8}{|l|}{ Chile } \\
\hline$I / G N P$ & 13.2 & 12.6 & 10.5 & 9.0 & 9.2 & n.a. & \\
\hline$S / G N P$ & 11.5 & 12.9 & -0.2 & 7.0 & 5.9 & n.a. & 1975 \\
\hline$C A / G N P$ & -2.9 & -0.8 & -6.7 & 1.4 & -3.3 & n.a. & \\
\hline \multicolumn{8}{|l|}{ Gabon } \\
\hline$I / G N P$ & n.a. & 55.8 & 91.5 & n.a. & 67.1 & n.a. & \\
\hline$S / G N P$ & n.a. & 63.2 & 47.8 & n.a. & 50.7 & n.a. & 1978 \\
\hline$C A / G N P$ & n.a. & 7.4 & -43.6 & n.a. & -16.4 & n.a. & \\
\hline \multicolumn{8}{|l|}{ Peru } \\
\hline$I / G N P$ & 12.7 & 15.3 & 17.5 & 16.9 & 14.9 & 14.5 & \\
\hline$S / G N P$ & 15.6 & 13.3 & 9.7 & 10.9 & 9.2 & 15.3 & 1978 \\
\hline$C A / G N P$ & 1.0 & -5.8 & -10.1 & -7.1 & -6.2 & 0.2 & \\
\hline \multicolumn{8}{|l|}{ Sierre Leone } \\
\hline$I / G N P$ & 13.2 & 12.0 & 13.4 & 12.7 & 11.9 & 12.8 & \\
\hline$S / G N P$ & 13.4 & 16.3 & 6.3 & 4.6 & 8.2 & 7.7 & 1976 \\
\hline$C A / G N P$ & -0.4 & 0.2 & -9.7 & -7.8 & -6.0 & -4.7 & \\
\hline \multicolumn{8}{|l|}{ Turkey } \\
\hline$I / G N P$ & 17.0 & 17.7 & 18.9 & 22.6 & 22.7 & 20.1 & \\
\hline$S / G N P$ & 22.8 & 21.9 & 21.8 & 21.7 & 21.3 & 22.6 & 1978 \\
\hline$C A / G N P$ & 5.0 & 2.8 & -0.5 & -1.9 & -3.6 & -0.1 & \\
\hline \multicolumn{8}{|l|}{ Zaire } \\
\hline$I / G N P$ & 28.4 & 32.0 & 28.9 & n.a. & n.a. & n.a. & \\
\hline$S / G N P$ & 21.5 & 19.0 & 9.5 & n.a. & n.a. & n.a. & 1976 \\
\hline$C A / G N P$ & -10.8 & -13.0 & -22.8 & n.a. & n.a. & n.a. & 1977 \\
\hline
\end{tabular}

Sources: All data except that for Turkey are from the International Monetary Fund, International Financial Statistics. The definitions of $S, I$, and $C A$ are the same as those in tables 8 and 9 , although no adjustment for inflation is made for these countries. The data for Turkey are from the Organisation for Economic Co-operation and Development, National Accounts of OECD Countries, 1950-1978 (Paris: OECD, 1980), and are similarly defined. n.a. Not available.

Projects that were profitable at the low real interest rates of 1974-77 may now have a negative present value.

On the optimistic side, for many LDCs total debt greatly overstates bank exposure because LDCs have substantial bank assets offsetting their bank liabilities. Moreover, the LDCs may be able to expand borrowing 
in the Eurobond markets, thereby diversifying the holdings of LDC debt and reducing bank exposure. In the same way, the growth of European bank lending to Mexico and Brazil may alleviate the fear that U.S. bank loans are too highly concentrated in these countries, which has occasionally led to spreads over LIBOR on Brazilian loans of more than 2 percent. $^{31}$

\section{CURRENT ACCOUNT CHANGES IN OECD COUNTRIES}

For the developed economies the data are available to compare the dependence on oil imports and current account movements in the 1970s. According to the theory developed here, a permanent oil price rise should not cause differential current account behavior in oil exporting and importing countries (abstracting from investment behavior) while a temporary shock should. There does in fact appear to be a systematic relation between oil dependence and deficits among the oil-importing countries, although that relation appears weak after 1975. It also appears that shifts in domestic investment rates are as important as oil-import dependence in interpreting recent current account movements. The behavior of investment helps to explain U.S. deficits whereas Germany and Japan had surpluses in 1977-78; the striking increases in deficits of the energy-exporting countries, Canada and Norway; and the very different current account behavior after the 1974 and 1979 oil shocks in the largest OECD economies.

As shown in the data on saving and investment in table 9, I/GNP declined between 1965-73 and 1974-79 in ten of fifteen countries. Only in Belgium, Canada, Finland, Norway, and the United Kingdom were rates of gross fixed capital formation maintained or increased. The rows labeled $I^{m} / I$, showing the share of mining and energy investment as a proportion of total investment, help to explain this divergence. Canada, Norway, and the United Kingdom are three of the four countries listed

31. See "The Great Brazilian Tightrope," Euromoney (January 1980), pp. 5068, and more recent issues of Euromoney. On the question of bank loans, see Edmar Bacha and Diaz-Alejandro, "Financial Markets: A View from the SemiPeriphery," p. 34. In December 1977 non-U.S. bank claims against Brazil and Mexico were $\$ 19.7$ billion out of $\$ 43.7$ billion (45 percent) in total claims against these countries. By June 1979 the non-U.S. bank claims had risen to $\$ 35$ billion out of $\$ 59.9$ billion (58 percent) in total claims. 
for which mining and energy investments account for more than 2 percent of gross fixed capital formation. ${ }^{32}$ The energy price increases after 1973 led to a major expansion of their energy production, which sustained overall investment rates.

These energy investments were largely financed through foreign capital inflows, as the model of the current account predicts. Norway is the outstanding case. After averaging 28 percent in 1965-73, its $I / G N P$ rose a full 10 percentage points in the next five years, with a substantial rise in the share of investment devoted to energy and energy-related projects, including the oil and gas pipeline between Norway and West Germany. ${ }^{33}$ The current account deficit rose about as much as investment. National saving rates did not have to rise, nor other investment rates fall, to allow for the exploitation of the North Sea oil. Major projects in the pipeline, oil production, and petrochemical plants were completed in 1978, and real fixed capital formation fell 16.1 percent between 1977 and 1979. The current account deficit disappeared also, falling to a mere 2.2 percent of GDP in 1979. It must be emphasized that despite Norway's extraordinary $C A$ deficits by OECD standards, reaching over 13 percent of GDP in 1977 , international capital markets remained open to Norwegian borrowing without increases in relative interest rates and without sharp depreciation of the Norwegian krona.

The importance of investment in OECD current account determination may be documented statistically. First, it should be noted that, although there are important changes in $C A / G N P$ over time, there is also a consistent ordering of countries in relative current account positions. Many countries, particularly the smaller European economies, have been regularly in deficit since 1960, while others, such as Germany and Japan, have been typically in surplus. The correlation between $C A / G N P$ for the 1965-73 subperiod and for 1974-79, across countries, is $r=0.65$. Moreover, with the important exception of Japan, there is a strong negative relation between the investment rates and current account positions of the countries. The countries that are typically in deficit have, on average,

32. Australia is the fourth, though apparently no post-1974 data on Australian sectoral investment are available from the OECD.

33. Mining and quarrying investments accounted for about 2.4 percent of total investments in 1970 and 16.6 percent at their peak in 1977. Adding transport investment, which includes the pipeline, the shares are 23.0 percent in 1970 and 34.4 percent in 1977. 
much higher investment rates than the surplus countries. ${ }^{34}$ For example, the simple correlation of $(I / G N P)_{74-79}$ and $(C A / G N P)_{74-79}$ is -0.61 . Excluding Japan, the correlation is -0.86 .

Table 14 reports regressions testing the importance of shifts in investment and saving and oil dependence in explaining changes in the current account.

In separate cross-country regressions of $\left[(C A / G N P)_{74-79}-(C A /\right.$ $G N P)_{68-73}$ ] on changes in investment rates and on changes in saving rates, the investment rate variable enters significantly and explains 72 percent of the cross-country variance. The shifts in saving explain virtually none of the variance, and are in fact negatively correlated with $\Delta(C A / G N P)$. There is no significant linkage between $\Delta(C A / G N P)$ and pre-1973 oil dependence, as seen in equations 14-3 and 14-4. When Norway is removed from the sample, $\Delta(I / G N P)$ remains an important explanatory variable, while $M^{o i l} / G N P$ rises slightly in importance. Other regressions for all countries, not shown, demonstrate that the effect of $\Delta(I / G N P)$ holds for various subperiods (for instance, $\left[(C A / G N P)_{76-78}-(C A)\right.$ $\left.G N P)_{68-73}\right]$ is closely related to $\left.\left[(I / G N P)_{76-78}-(I / G N P)_{68-73}\right]\right)$, and is not merely a reflection of the 1974-75 recession.

A puzzle emerges when one examines the subgroup of oil-importing countries, excluding Australia, Canada, Norway, and the United Kingdom. Without these countries, $\Delta(C A / G N P)$ shows a strong negative correlation with $\left(M^{o i l} / G N P\right)_{68-73}$, as seen in equation 14-6. Specifically, a 1 percentage point greater oil dependence in 1968-73 corresponds to a drop in (CA/GNP) of fully 0.9 percentage point in 1974-79. Higher investment rates in the oil-dependent economies do not seem to explain this correlation, as shown in equation 14-7. On closer examination, however, the correlation between $\Delta(C A / G N P)$ and $M^{o i l} / G N P$ comes primarily from the first years after the oil shock, as comparison of equations 14-8 and $14-10$ shows. Also, in the $1974-75$ period, $\Delta(I / G N P)$ dominates

34. For further discussion, which shows that smaller European economies are characterized by relatively high $I / G N P$ and low $C A / G N P$, see Jeffrey Sachs "Aspects of the Current Account Behavior of the OECD Economies," presented at the fifth International Conference of the University of Paris-Dauphine on Money and International Monetary Problems, June 15 to 17, 1981. Japan's small surplus and high investment rates probably reflect a policy of tight capital controls until the mid-1970s. The controls were designed to channel the high Japanese saving rates into domestic investment. In the absence of controls, Japan would most likely have had higher $C A / G N P$ and lower $I / G N P$. 
Table 14. Equations Explaining the Change in the Ratio of the Current Account to GNP, $\Delta(C A / G N P)$, Selected Countries and Periods, 1968-79a

\begin{tabular}{|c|c|c|c|c|c|c|}
\hline \multirow{2}{*}{$\begin{array}{l}\text { Country } \\
\text { group and } \\
\text { equation }\end{array}$} & \multicolumn{2}{|c|}{ Period } & \multicolumn{3}{|c|}{ Independent variable } & \multirow[b]{2}{*}{$\bar{R}^{2}$} \\
\hline & First & Second & $M^{o i l} / G N P$ & $\Delta(I / G N P)$ & $\Delta(S / G N P)$ & \\
\hline \multicolumn{7}{|l|}{ All countries } \\
\hline $14-1$ & $1968-73$ & $1974-79$ & $\ldots$ & $\begin{array}{l}-0.61 \\
(-6.2)\end{array}$ & $\ldots$ & 0.72 \\
\hline $14-2$ & $1968-73$ & $1974-79$ & $\ldots$ & $\ldots$ & $\begin{array}{l}-0.34 \\
(-1.0)\end{array}$ & 0.00 \\
\hline $14-3$ & $1968-73$ & $1974-79$ & $\begin{array}{l}-0.61 \\
(-1.27)\end{array}$ & $\ldots$ & $\cdots$ & 0.04 \\
\hline $14-4$ & $1968-73$ & $1974-79$ & $\begin{array}{l}-0.30 \\
(-1.18)\end{array}$ & $\begin{array}{l}-0.59 \\
(-5.9)\end{array}$ & $\ldots$ & 0.73 \\
\hline \multicolumn{7}{|l|}{$\begin{array}{c}\text { All countries, } \\
\text { excluding } \\
\text { Norway }\end{array}$} \\
\hline $14-5$ & $1968-73$ & $1974-79$ & $\begin{array}{l}-0.32 \\
(-1.5)\end{array}$ & $\begin{array}{l}-0.33 \\
(-2.6)\end{array}$ & $\ldots$ & 0.37 \\
\hline \multicolumn{7}{|l|}{$\begin{array}{l}\text { Oil-importing } \\
\text { countries }\end{array}$} \\
\hline $14-6$ & $1968-73$ & $1974-79$ & $\begin{array}{l}-0.89 \\
(-2.8)\end{array}$ & $\ldots$ & $\ldots$ & 0.37 \\
\hline $14-7$ & $1968-73$ & $1974-79$ & $\begin{array}{c}-0.70 \\
(-1.97)\end{array}$ & $\begin{array}{l}-0.21 \\
(-1.1)\end{array}$ & $\ldots$ & 0.38 \\
\hline $14-8$ & $1968-73$ & $1974-75$ & $\begin{array}{c}-1.74 \\
(-2.49)\end{array}$ & $\cdots$ & $\cdots$ & 0.29 \\
\hline $14-9$ & $1968-73$ & $1974-75$ & $\begin{array}{l}-0.56 \\
(-1.0)\end{array}$ & $\begin{array}{l}-0.71 \\
(-3.5)\end{array}$ & $\cdots$ & 0.71 \\
\hline $14-10$ & $1968-73$ & $1976-78$ & $\begin{array}{c}-0.43 \\
(-0.75)\end{array}$ & $\cdots$ & $\cdots$ & -0.17 \\
\hline $14-11$ & $1968-73$ & $1976-78$ & $\begin{array}{l}-0.20 \\
(-0.32)\end{array}$ & $\begin{array}{c}-0.28 \\
(-0.90)\end{array}$ & $\ldots$ & -0.19 \\
\hline
\end{tabular}

Sources: Calculations by the author.

a. The dependent variable is average $(C A / G N P)_{\text {period } 2}$ minus average $(C A / G N P)_{68-73}$. The "all countries" category in this table and the $I$ and $S$ are the same as those in table 9. Nonoil countries exclude Australia, Canada, Norway, and the United Kingdom. For all regressions, Moil/GNP is the net import of the standard international trade classification (SITC 3) as a percent of GNP, with the ratio averaged over $1968-73$. The variable $\Delta(I / G N P)$ is average $(I / G N P)_{\text {period } 2}$ minus average $(I / G N P)_{68-73}$; the variable $\Delta(S / G N P)$ is average $(S / G N P)_{\text {period } 2}$ minus average $(S / G N P)_{68-73}$. The numbers in parentheses are $t$ statistics. 
$M^{\text {oil }} / G N P$, as seen in 14-9. When the cyclical years immediately following the oil shock are deleted, as in equations 14-10 and 14-11, neither oil dependence nor investment explains current accounts among nonoil economies.

\section{THE SPECIAL CASES OF THE UNITED STATES, GERMANY, AND JAPAN}

Looking at the U.S., Japanese, and German current accounts as a portion of income conceals their quantitative importance to international capital markets. Even in 1978, the year of the largest U.S. trade and current account deficits- $\$ 33.8$ billion and $\$ 14$ billion, respectively-the U.S. deficit was no more than 0.7 percent of GNP. But the $\$ 14$ billion reflected a large amount of borrowing from the rest of the world. The 1978 Japanese surplus ( $\$ 16.5$ billion) more than matched the U.S. deficit, and the combined German ( $\$ 8.7$ billion) and Japanese surpluses were over one and a half times the U.S. deficit.

After the first oil shock, a deep recession coupled with a sharp drop in real fixed capital formation caused large surpluses in the United States, Germany, and Japan. Because of an exceptional fall in the before-tax rate of return to capital in Germany and Japan, investments in GNP fell below the historical trend (see table 9) and did not begin to recover until 1979. As is well known, U.S. profitability recovered substantially after 1975; indeed, the cyclically adjusted before-tax rate of returns to U.S. capital does not appear to have fallen after the OPEC shock. ${ }^{35}$ The U.S. cyclical recovery was led by an investment boom, and the rate of gross fixed capital formation as a percentage of income returned to the 1965-73 average. In all three countries the rate of growth of real fixed capital formation slowed after 1973, but slowed much more markedly in Germany and Japan. Between 1965 and 1973, real fixed capital formation grew 28 percent in the United States, as compared with 33 percent in Germany and 197 percent in Japan; between 1973 and 1978, the growth in these countries was 2.6 percent, zero percent, and 6.0 percent, respectively. ${ }^{36}$ National saving rates in Germany and Japan fell more than in the

35. See Sachs, "Wages, Profits, and Macroeconomic Adjustment."

36. See Organisation for Economic Co-operation and Development, National Accounts of OECD Countries, 1961-1978 (Paris: OECD, 1980), vol. 2, pp. 19, 31, 105. 
United States after 1973; the differential investment experience more than explains the relative current account movements.

A striking comparison can be drawn between the current account responses to the oil shocks in 1973 and in 1979. There has been a sharp difference in the response of real wages to the second oil shock, with a corresponding difference in investment patterns. The 1981 Economic Report of the President notes:

In 1974-75 unit labor costs [outside the United States] rose much more than value-added deflators for manufacturing. This implied a sharp rise in the labor share of total value added, and a corresponding fall in the profit share, which was only gradually restored in subsequent years. The squeeze on profits was a major cause of low rates of investment in most foreign countries during the following years....

In $1979-80$, the increase in unit labor costs in major foreign countries remained less than the rise in value-added deflators, thus giving manufacturers some room to absorb increased energy costs without a major squeeze on profit margins. ${ }^{37}$

And this has been specifically true in Germany and Japan.

For Japan:

When the second oil crisis hit the Japanese economy, it was not far from the full employment situation. ... The profit squeeze effect, which could have decreased the supply of manufactures by as much as 13 percent, was prevented from taking place because of a substantial cut in the real wage cost. A recession did not materialize, and, moreover, the oil-induced inflation has been largely avoided. ${ }^{38}$

\section{For Germany:}

The decline in the labor share in national income since 1975, which was interrupted only in 1977, thus continued [in 1979]. This adjustment of the wage share has been widely accepted, in order to increase investment propensities required to attain full employment in the median run. Nevertheless, the continuation of this process in 1979 is remarkable, since, contrary to 1978 , termsof-trade developments reduced considerably the margin of distributable national income. ${ }^{39}$

In line with the arguments set forth in my earlier $B P E A$ paper, the oil shock of 1979 had a much smaller impact on investment than the 1974

37. Economic Report of the President, January 1981, pp. 184-85.

38. Yoichi Shinkai, "Oil Crisis and the Stagflation (or Its Absence) in Japan," Discussion Paper 110 (Osaka University, Institute of Social and Economic Research), p. 13.

39. OECD Economic Surveys: Germany (Paris: OECD, May 1980), p. 20. 
shock. Indeed, 1979 was a boom year abroad for fixed investment. ${ }^{40}$ The result has been a swing into deficit in Germany and Japan, in contrast to Germany's widening surplus in 1974. For 1981, OECD forecasts a $\$ 19$ billion U.S. surplus offsetting a $\$ 17$ billion combined German and Japanese deficit. ${ }^{41}$

\section{Changes in the Exchange Rate and in Current Accounts}

Rudiger Dornbusch's recent survey of exchange rate models examined the possible theoretical links between the current account and floating exchange rates. ${ }^{42}$ Professional thinking about these links has gone through a number of stages. Keynesian models in the 1950s and 1960s focused on the role of exchange rate movements in closing account imbalances. In a world of capital immobility, a floating exchange rate $e$ must adjust until $C A$ equals zero. Mundell and Fleming introduced the opposite assumption of perfect capital mobility, severing this connection between $e$ and $C A$. In the Mundell-Fleming model a fiscal expansion causes an exchange rate appreciation at the same time that it widens the current account deficit. Models of global monetarism and full-employment equilibrium further weakened the $e-C A$ connection. ${ }^{43}$ These models underscored the fact that $e$ is a nominal variable while $C A$ is a real variable, so that there need be no link between the two in a world devoid of money illusion.

Other theoretical work, particularly that of Kouri and Branson, has continued to stress the link between the exchange rate and the current account, and those views received particular prominence with the 1977-

40. Jeffrey D. Sachs, "Wages, Profits, and Macroeconomic Adjustment.

41. Cited in Economic Report of the President, January 1981, table 29, p. 187.

42. Rudiger Dornbusch, "Exchange Rate Economics: Where Do We Stand?" $B P E A, 1: 1980$, pp. 143-85.

43. Robert A. Mundell, "Capital Mobility and Stabilization Policy under Fixed and Flexible Exchange Rates," Canadian Journal of Economics and Political Science, vol. 29 (November 1963), pp. 475-88, reproduced in Richard E. Caves and Harry G. Johnson, eds., Readings in International Economics (Irwin, 1968), pp. 487-99; and J. Marcus Fleming, "Domestic Financial Policies under Fixed and Floating Exchange Rates," IMF Staff Papers, vol. 9 (November 1962), pp. 369-80, reproduced in Richard N. Cooper, ed., International Finance: Selected Readings (Penguin, 1969), pp. 291-303. 
78 depreciation of the dollar and the accompanying huge current account deficits. In a series of papers, Kouri, Branson, and others have shown how current account imbalances induce a reshuffling of assets among home and foreign portfolios, with resulting shifts in interest rates on assets of different currency denominations. These interest rate fluctuations in turn induce changes in the exchange rate. ${ }^{44}$ In other recent work, Dornbusch and Fischer have stressed the wealth effects of current account deficits on money demand. Because a deficit implies rising indebtedness to the rest of the world, and perhaps falling domestic wealth, the demand for home money may fall if money holdings are a rising function of wealth..$^{45}$ The fall in money demand, for a given nominal money supply, results in exchange rate depreciation. In still another view linking exchange rates and the current account, Stockman and Mussa have argued that changes in nominal exchange rates are often a reflection of real exchange rate changes-that is, shifts in relative prices across countries-that are brought about by nonmonetary disturbances in the economy. These real shocks may cause current account deficits and real exchange rate depreciations, leading to a statistical correlation of the current account and nominal exchange rate movements. ${ }^{46}$

These relations can be succinctly described in a simple monetary framework. The equations should be considered part of a general equilibrium model and not a self-contained theory of the exchange rate. The real exchange rate, or the inverse of the home country terms of trade, can be expressed as $\pi=\left(e P^{*} / P\right)$. A fall in $\pi$ is a real exchange rate appreciation, and a rise is a depreciation. The $\pi$ is driven by shifts in the supply and demand for home goods relative to foreign goods. The exchange rate can

44. See Pentti J. K. Kouri, "The Exchange Rate and the Balance of Payments in the Short-Run and in the Long-Run: A Monetary Approach," Scandinavian Journal of Economics, vol. 78, no. 2 (1976), pp. 280-304; and Pentti J. K. Kouri and Jorge Braga de Macedo, "Exchange Rates and the International Adjustment Process," BPEA, 1:1978, pp. 111-50. An empirical implementation of this view is in William H. Branson, Hannu Halttunen and Paul Masson, "Exchange Rates in the Short-Run: The Dollar-Deutschemark Rate," European Economic Review, vol. 10 (December 1977), pp. 303-24.

45. See Rudiger Dornbusch and Stanley Fischer, "Exchange Rates and the Current Account," American Economic Review, vol. 70 (December 1980), pp. 960-71.

46. See Mussa, "The Role of the Current Account in Exchange Rate Dynamics"; and Stockman, "A Theory of Exchange Rate Dynamics" and "Exchange Rates, Relative Prices, and Resource Allocation." 
be written $e=\pi\left(P / P^{*}\right)$. Money-demand functions take the form:

$$
\begin{gathered}
\frac{M}{P}=m(i, Y, W), \quad \frac{M^{*}}{P^{*}}=m^{*}\left(i^{*}, Y^{*}, W^{*}\right) \\
m_{1}, m_{1}^{*}<0 ; \quad m_{2}, m_{2}^{*}>0 ; \quad m_{3}, m_{3}^{*}>0,
\end{gathered}
$$

where $i$ is the nominal interest rate, $Y$ is real income, and $W$ is total wealth in the economy. For convenience, these functions are assumed to be of semilog form,

$$
\frac{M}{P}=(1+i)^{-\beta} Y^{\gamma} W^{\alpha}, \quad \frac{M^{*}}{P^{*}}=\left(1+i^{*}\right)^{-\beta} Y^{* \gamma} W^{* \alpha}
$$

If $i^{f}$ is the expected return on the foreign asset in domestic currency units, then

$$
1+i^{f}=\frac{E\left(e_{t+1}\right)}{e_{t}}\left(1+i^{*}\right)
$$

Let $\phi$ be the risk premium on the home asset, so that

$$
\phi=i-i^{f} \cong \frac{1+i}{1+i^{f}}
$$

From the relation $e=\pi\left(P / P^{*}\right)$ and the money-demand functions, a quasi-reduced form can be written for $e_{t}$ :

$$
e_{t}=\pi\left(\frac{M}{M^{*}}\right) \phi^{\beta}\left[\frac{E\left(e_{t+1}\right)}{e_{t}}\right]^{\beta}\left(\frac{Y^{*}}{Y}\right)^{\gamma}\left(\frac{W^{*}}{W}\right)^{\alpha} .
$$

The final form for $e_{t}$ depends on $E\left(e_{t+1}\right)$, which in turn is a function of expected future monetary policy and future changes in $\pi, Y, Y^{*}, W$ and $W^{*}$. Therefore $e_{t}$ depends on the entire future path of exogenous and policy variables. Here, it will suffice to hold $E\left(e_{t+1}\right)$ fixed, and to discuss current period changes in the remaining variables. ${ }^{47}$ To complete the model, equations are needed to describe $Y, Y^{*}, W, W^{*}, \pi, M, M^{*}$, and expectations formation.

Equation 14 illustrates as special cases the three views of the linkage between the current account and the exchange rate. The Kouri-Branson position lies in the association of a deficit with a rise in $\phi$, which clearly increases $e$. The primary effect of a deficit is regarded as the reduction

47. Suppose, for example, that it is widely anticipated that monetary authorities will peg the future nominal exchange rate. 
in net holdings of foreign-denominated assets, which raises the equilibrium spread between $i$ and $i^{f}$. The Dornbusch-Fischer approach posits that changes in $W$ result from $C A$ imbalances; from 14 a decline in wealth causes $e$ to rise. Finally, the Mussa-Stockman view is that a current account deficit may be associated with a rise in $\pi$, and thus a rise in $e$.

The linkages between $e$ and $C A$ are hardly rigid. Purely monetary disturbances, such as expected changes in current $M / M^{*}$ or future $M / M^{*}$, can affect $e$ with little impact on the current account. Wealth changes may provide a link between $e$ and $C A$, but in a "perverse" direction. Current account deficits signify a drop in a country's net foreign investment position but do not necessarily denote a drop in total wealth. It may well be that the wealth of countries with deficits is growing faster than the wealth of those with surpluses if the deficits reflect a boom in home investment. Moreover, measured effects of wealth on money demand tend to be small or negligible.

Changes in $\pi$ could provide a connection between $C A$ and $e$, though not always in the supposed direction. Suppose that $C A$ movements are largely a result of investment shocks, caused by shifting estimates of future profitability ( $\theta_{2}$ in the earlier model). A rise in $I$ and the resulting deficit will be accompanied by a rise in domestic prices relative to foreign prices, and $\pi$ will fall, if the investment demand is concentrated in home goods. According to 14, $C A$ deficits will, other things being equal, be accompanied by nominal and real exchange rate appreciation. If the investment boom is temporary, the deficits will give way over time and $\pi$ will rise. Hence, a deficit will be followed by a real depreciation. The real depreciation may appear to have "caused" the restoration of current account balance. In fact, $e$ and $C A$ are responding jointly to a more fundamental shock.

Note that the correlation between $\pi$ and $C A$ can be of either sign. The following results are easy to establish in a two-good, two-period, twocountry model: (1) a temporary boom today (increase in $\phi_{1}$ ) raises $\pi$ and $C A$; (2) a temporary increase in export demand (increase in $Y_{1}^{*}$ ) lowers $\pi$ and raises $C A$; and (3) a permanent increase in export demand (increase in $\left.Y_{1}^{*}, Y_{2}^{*}\right)$ lowers $\pi$ and may reduce $C A$. Many other examples are also possible.

Finally, there is the exchange-risk or interest-differential mechanism. Portfolio models such as in those of Dornbusch and Kouri and de Macedo typically take $\phi$ to be a function of the net wealth of home and foreign 
residents and the outstanding stocks of assets in various currency denominations. ${ }^{48}$ Because these determinants of $\phi$ change slowly, the $\phi$ is expected to move very gradually over time ${ }^{49}$ Many researchers have attempted without success to isolate a stable value of $\phi$ for various major currencies, although the hypothesis $\phi=0$ has been repeatedly rejected.

In my view, the determination of $\phi$ has been modeled too restrictively by focusing on risk but not on the role of extensive capital-flow regulations in many countries. As Dooley and Isard recently showed for Germany in the 1970-74 period, capital controls can account for significant interest rate differentials between home and foreign assets even apart from risk considerations. ${ }^{50}$ Regulations impose implicit and explicit costs of intermediation between national financial markets. Lenders in one country can be encouraged to lend to foreign firms only if the foreign-domestic interest rate differential is high enough to surmount official barriers to capital outflows.

Capital controls may result in an arbitrage schedule linking $\phi$ to the current account. As foreign borrowing rises ( $C A$ falls), the marginal cost of funds rises. As $\phi$ grows, home interest rates rise above $i^{*}$, and $e$ depreciates according to 14. Suppose, for example, that restrictions on incremental borrowing imply that the current account must be greater than $\overline{C A}$. A rise in home investment demand may then result in an increase in home interest rates above the world interest rate-that is, a rise in $\phi$-and a deficit at the maximum permitted level. The deficit will be associated with an exchange rate depreciation. In this view, $\phi$ may be quite volatile because it does not result from slowly changing risk factors.

\section{EVIDENCE ON EXCHANGE RATES}

AND THE CURRENT ACCOUNT

Despite the voluminous literature analyzing the links of $e$ and $C A$, there has been very little systematic description of the historical relation between these variables for OECD economies. Table 15 summarizes that

48. Dornbusch, "Exchange Rate Economics," and Kouri and de Macedo, "Exchange Rates and the International Adjustment Process."

49. It might be argued that while asset stocks move slowly, market estimates of the covariances that underlie the stock demand functions change rapidly.

50. See Michael P. Dooley, and Peter Isard, "Capital Controls, Political Risks and Deviations from Interest-Rate Parity," Journal of Political Economy, vol. 88 (April 1980), pp. 370-84. 


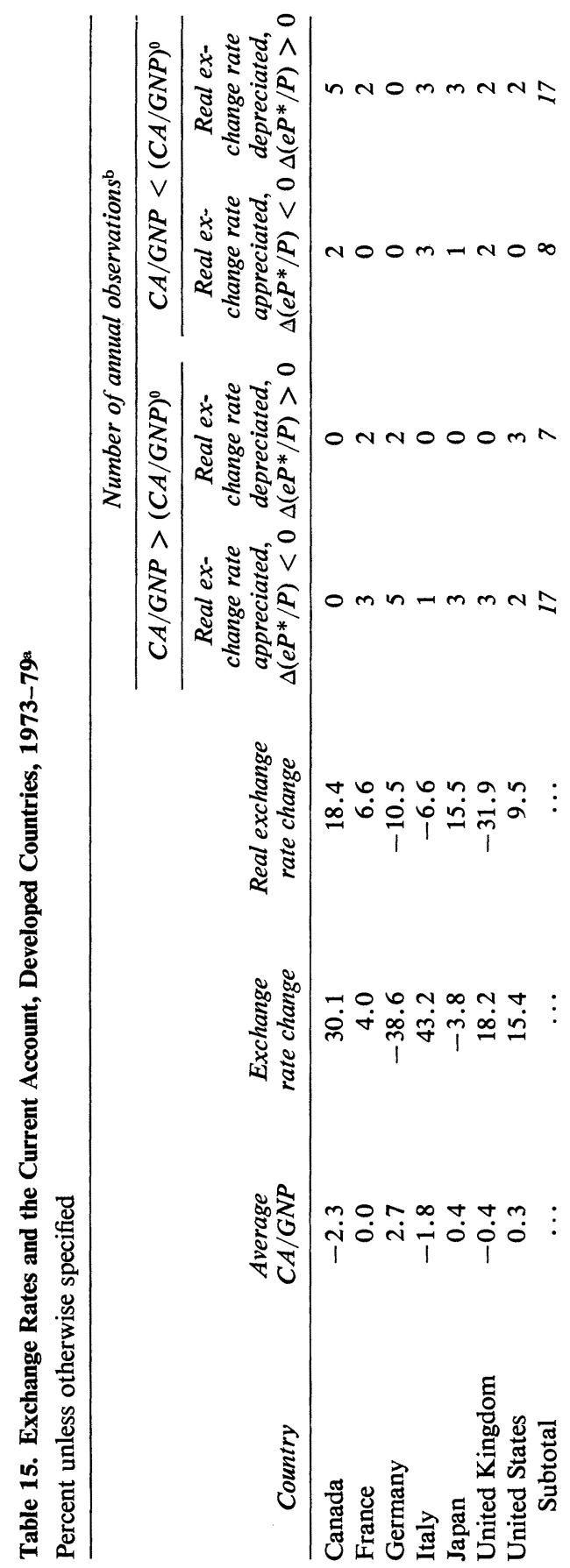




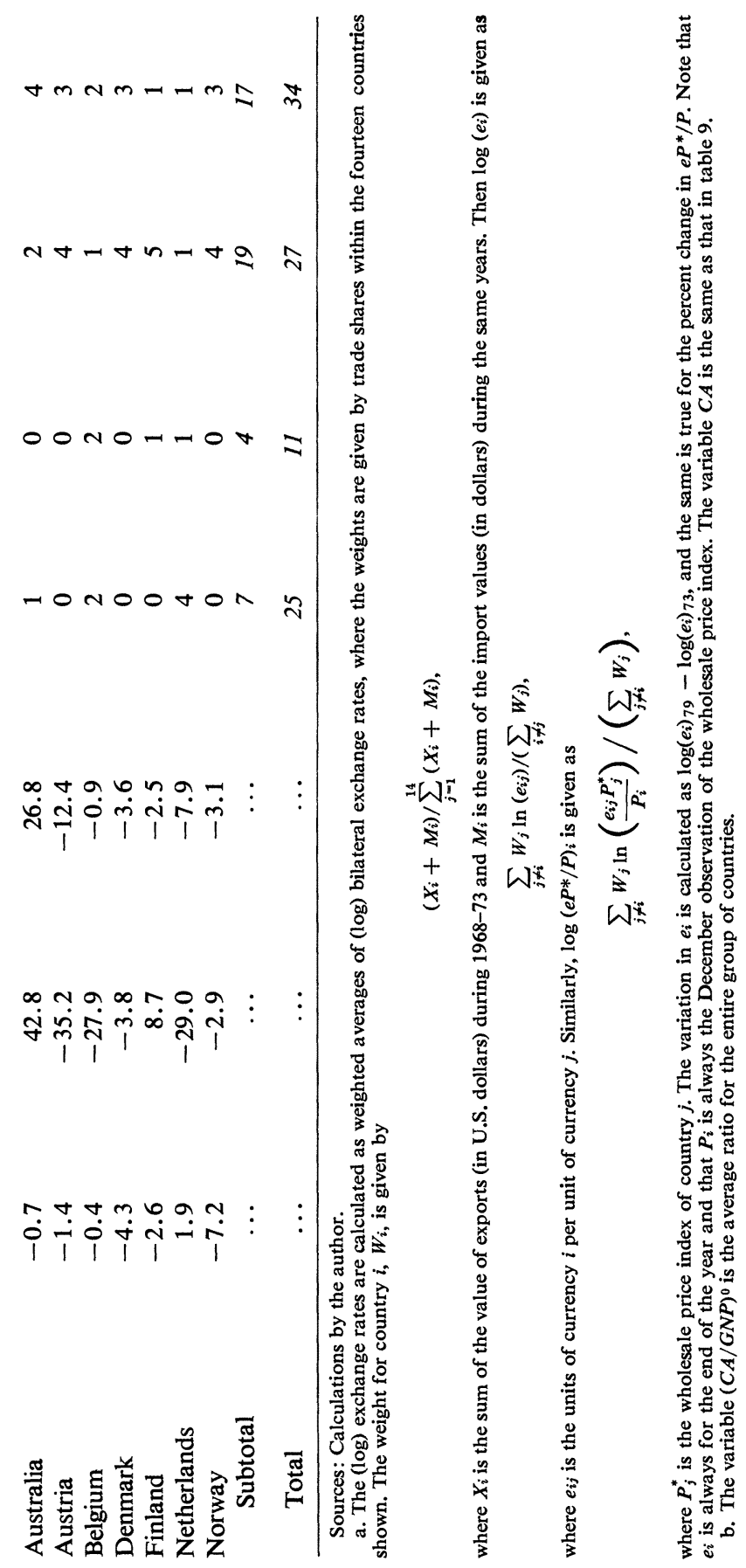


experience. The table should dispel any simple notions about linkages between $e$ and $C A$, though some important patterns are discernible. Overall many deficit countries experienced nominal and real exchange rate appreciation, while countries with surpluses (including the United States and Japan) showed nominal and real exchange rate depreciations. The smaller countries-Austria, Belgium, Denmark, Finland, and Norwayshow significant current account deficits and real exchange rate appreciation during the period. The real exchange rate is defined in terms of the wholesale price index, and these conclusions might vary with a different price measure.

In table 15 I also examine whether countries with deficits in fact experience real depreciations, and countries with surpluses, real appreciations. For this purpose, a country is said to be in "deficit" when its $C A / G N P$ ratio is less than the average $C A / G N P$ ratio for the entire group of countries, denoted as $(C A / G N P)^{0}$ in the table. ${ }^{51}$ For the seven large countries with seven annual observations each, the hypothesis fares well. Of the forty-nine annual observations for the large countries, almost 70 percent show deficit years associated with depreciation or surplus years with appreciation. In a $\chi^{2}$ test of independence of $C A / G N P$ and the percentage change in $\left(e P^{*} / P\right)$, independence can be rejected at $p=0.05$. The story is quite different for the smaller countries, where 50 percent of the observations reject the basic hypothesis. The smaller countries appear to be on long-run growth paths that are characterized by real exchange rate appreciation and current account deficits. Perhaps the appropriate test for these countries is whether deficits greater than "normal" are associated with smaller-than-normal real exchange rate appreciations. I have not yet examined this question.

For most countries, including the United States, a positive relation exists between the level of $\ln \left(e P^{*} / P\right)$ and $\left[C A / G N P-(C A / G N P)^{\circ}\right]$ (with both measured as deviations from linear trend). In annual data for $1960-79, \ln \left(e P^{*} / P\right)$ and $\left[C A / G N P-(C A / G N P)^{\circ}\right]$ are positively correlated for ten of thirteen countries. This is as expected when shifts in the current account originate from shocks to home demand: periods of high demand are characterized by low $e P^{*} / P$ and $C A / G N P$; the reverse is true for periods of low demand.

51. Because the real exchange rate is a relative price that prevails between countries, relative prices must be compared with relative current account positions and not merely the current account position of a particular country. 
Figure 4 helps to put in perspective the U.S. real exchange rate depreciation in 1977-78. It compares the U.S. GDP deflator in manufacturing relative to an average of deflators of other countries with the ratio of $C A$ to GNP for the United States. The correlation of $C A / G N P$ and $\ln \left(e P^{*} / P\right)$, with both as deviations from linear trend, is 0.50 over the 1961-79 period. There is a marked trend depreciation in 1960-80 in the U.S. real exchange rate, measured by the relative deflators, which is punctuated by an episode of real appreciation in 1975-76, measured by improvements relative to trend in the relative deflator. In this case, significant deficits followed appreciation. A nominal exchange rate depreciation (not shown) restored $P / e P^{*}$ to its downward trend. The deficit can be traced to a temporary spending boom during the U.S. cyclical recovery in 1976-78 when investment in Europe and Japan remained depressed. The large nominal depreciation in 1978 again reduced the real exchange rate relative to its historical trend. In this view, the deficits on the current account in 1977 and 1978 are not the primary cause of the dollar depreciation. Rather, the deficits are associated with a previous real exchange rate appreciation caused by a temporary investment boom. As the investment boom ended, a nominal depreciation brought the real exchange rate below its downward trend. Econometric evidence in support of the view that nominal exchange rates have moved to accomplish real exchange movements may be found in the study by Hooper and Morton. ${ }^{52}$

Other theories of the exchange rate do not explain these developments well. Purely monetary explanations founder on two points: they do not explain the persistent real exchange rate movements for the two years after 1977, and they miss the more basic point that the U.S. money supply was growing less rapidly, and accelerated less, than that of Germany or Japan..$^{53}$ The wealth effects of the U.S. deficit are too small to explain much. The $\$ 16$ billion deficit in 1977 was approximately 0.3 percent of national wealth, too small to explain the large drop in the effective

52. Hooper and Morton, "Fluctuations in the Dollar."

53. Consider the annual growth rates of M1 from 1976 to 1979 for the United States, Germany, and Japan; taken from McKinnon: United States-5.7, 8.8, 7.3, 6.1; Germany-3.9, 11.9, 14.5, 3.6; and Japan-12.5, 8.2, 13.4, 3.0. See Ronald McKinnon, "Currency Substitution and Instability in the World Dollar Standard," Memorandum 242 (Center for Research in Economic Growth, Stanford University, August 1980); and Jeffrey A. Frankel, "The Mystery of the Multiplying Marks: A Modification of the Monetary Model" (Department of Economics, University of California, Berkeley, August 1980). 
Figure 4. The U.S. Relative GDP Deflator for Manufacturing and the Ratio of the Current Account to GNP, 1961:1-1979:4
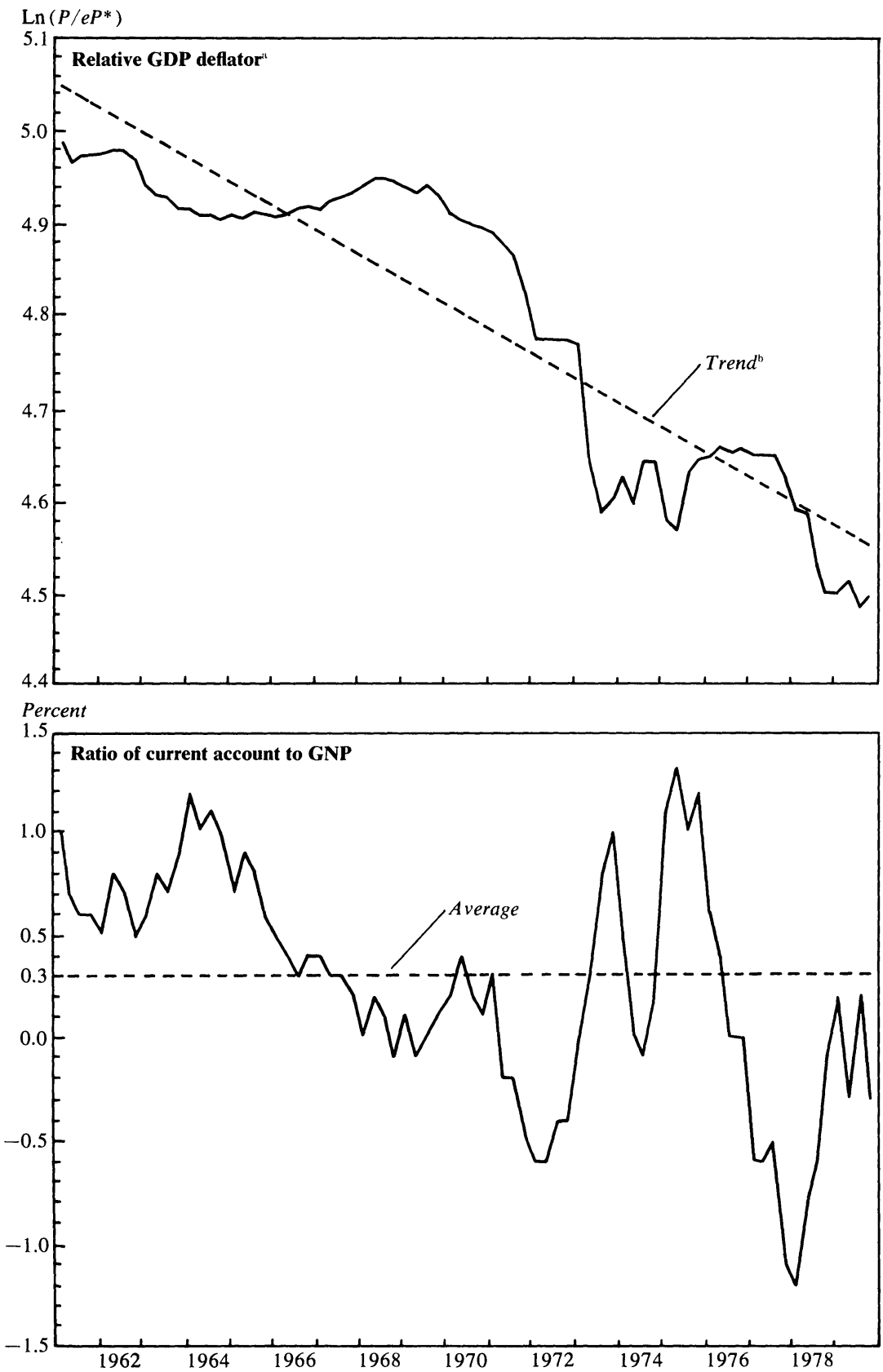

Sources: GDP deflator-calculations by the author based on the International Monetary Fund, International Financial Statistics, various issues, series 99 by 110 for the United States; current account-the Organisation for Economic Co-operation and Development, Main Economic Indicators, various issues; GNP-International Monetary Fund, International Financial Statistics, various issues.

a. The relative U.S. GDP deflator for manufacturing, $P / e P *$, is an index reflecting the ratio of that deflator to a weighted geometric average of the same deflator for thirteen other industrial countries, after expression of all the national indicators in terms of a common currency. The trend is calculated by regressing $\ln \left(P / e P^{*}\right)$ on time. 
exchange rate by the mechanism suggested by Dornbusch and Fischer. Moreover, wealth in the United States in toto was probably growing more rapidly relative to trend than in Germany or Japan, given the slowdown in capital accumulation in those countries. Finally, Frankel has recently shown the inadequacy of the portfolio view in interpreting the depreciation. Among other things, the stock of deutsche mark-denominated government debt, expanded more rapidly than the stock of dollar-denominated debt over the period under consideration. ${ }^{54}$

This discussion should not imply that either real factors or monetary factors typically account for exchange rate movements; indeed, the reverse is true. The correlation between $e$ and other variables of interest will not be stable across subperiods because such correlations merely reflect the predominance of some source of disturbance in the period being considered. Attempts to explain exchange rate "news" as a function of other sources of news, can be misleading. Although news matters, unanticipated changes in $C A, G N P, i$, or other economic variables can come from a variety of real or monetary shocks, each of which implies a distinct type of exchange rate adjustment.

\section{Conclusions}

This paper takes a step toward integrating analysis of the current account with modern theories of saving and investment. While the absorption and elasticities approaches to the current account have long ago been integrated, the current account is still often analyzed in a partial equilibrium framework by focusing on import and export demand relations. Moreover, economic and political thinking is still caught up in the mercantilist idea that deficits reflect overspending and therefore require adjustment. In fact, the current account flows in the 1970s reflect an interaction between OPEC saving and shifting worldwide investment patterns. These are cases of rising deficits caused by declining saving for particular LDCs that faced sharp terms-of-trade losses on important export items. However, most of the recent LDC borrowing was accounted for by the LDCs with large saving and investment flows-those that are enjoying 
the fruits of promising investment opportunities without the need to squeeze current consumption.

Economic policymakers have worried that deficits imply a depreciation of the exchange rate, with inflationary consequences. As shown above, such a simple linkage is only one theoretical possibility and does not predominate in cross-country data. The link is often severed when capital controls are absent, so that foreign borrowing can proceed at the world interest rate.

The empirical evidence in this paper is clearly rudimentary, though suggestive, on a number of key points. Further econometric work is needed to derive useful equations for the current account that distinguish between responses to transitory and permanent shocks. A great deal of work remains to be done in explaining the terms of international borrowing, particularly the spreads and maturities on Euromarket loans to the LDCs. One of the crucial issues of international economic policy in this regard involves the continued willingness of international banks to refinance and expand Brazil's enormous debt. Also, there should be a focus on the determinants of world interest rates and how they affect world income distributions-for example, among OPEC, nonoil LDCs, and OECD countries - and the profitability of investment in various major regions.

\section{A P PENDIX}

\section{Accounting for Capital Gains and Losses on International Investments}

THE high inflation and high indebtedness of the nonoil LDCs in the late 1970s has contributed to a major overstatement of LDC current account deficits. The national accounts record the nominal interest charges on this debt as a service account debit but do not record the inflation-induced erosion in real value of the debt as an offsetting credit. Stated differently, the accounts record the nominal, not real, interest charges as outflows of the service account. With high inflation, nominal interest charges can be several hundred percent, or of the opposite sign, of real interest costs. 
If $B^{*}$ is the amount of foreign-currency denominated debt, then

$$
\frac{B_{t}^{*}}{P_{t}^{*}}\left(1-\frac{P_{t}^{*}}{P_{t+1}^{*}}\right)
$$

is the value of capital gains earned on the foreign debt, expressed in units of the foreign good. Total interest costs are given as

$$
\frac{i^{*} B_{t}^{*}}{P_{t}^{*}}-\frac{B_{t}^{*}}{P_{t}^{*}}\left(1-\frac{P_{t}^{*}}{P_{t+1}^{*}}\right), \quad \text { or } \quad \frac{B^{*}}{P_{t}^{*}}\left(i^{*}-\frac{P_{t+1}^{*}-P_{t}^{*}}{P_{t}^{*}}\right),
$$

but only $i^{*} B_{t}^{*} / P_{t}^{*}$ is officially recorded. To make the appropriate adjustments from measured to total interest costs, it is necessary to know the value of outstanding interest bearing assets, their currencies of denomination, and the rates of inflation of those currencies.

The first two variables are not easily determined. It is very difficult to measure the outstanding net foreign investment position, and even more so to differentiate between interest-bearing and equity positions. Moreover, short-term credits (maturing in less than one year) are notoriously underreported, and there are no estimates of short-term foreign investment positions for the LDCs or the OECD countries as a whole. Currency of denomination is almost never reported except in specific markets (such as the Eurodollar market or foreign exchange reserves), and the effective currency of denomination can easily be altered for a given debt by taking a net position in a forward currency market.

To make the approximate calculations shown in text, I assume that all interest-bearing debt and foreign exchange reserves are dollardenominated, ignore all short-term credits, and assume that OPEC's net investment position in 1967, aside from foreign exchange reserves, was zero. Then, the debt of the nonoil LDCs to the OECD and to OPEC is taken from OECD, Development Co-Operation, statistical annex, "Total Debt of Developing Countries (Disbursed) At Year End, and Total Annual Debt Service For Selected Groups of Developing Countries," various issues. Net foreign exchange positions for OPEC and the oil-importing LDCs are from the International Monetary Fund, International Financial Statistics. OPEC total claims are calculated by cumulating OPEC current account surpluses from 1967 and subtracting direct foreign investment outflows. OPEC claims on the OECD countries are then calculated as total OPEC claims, minus foreign exchange accumulation since 1967, minus OPEC claims on nonoil LDCs. 


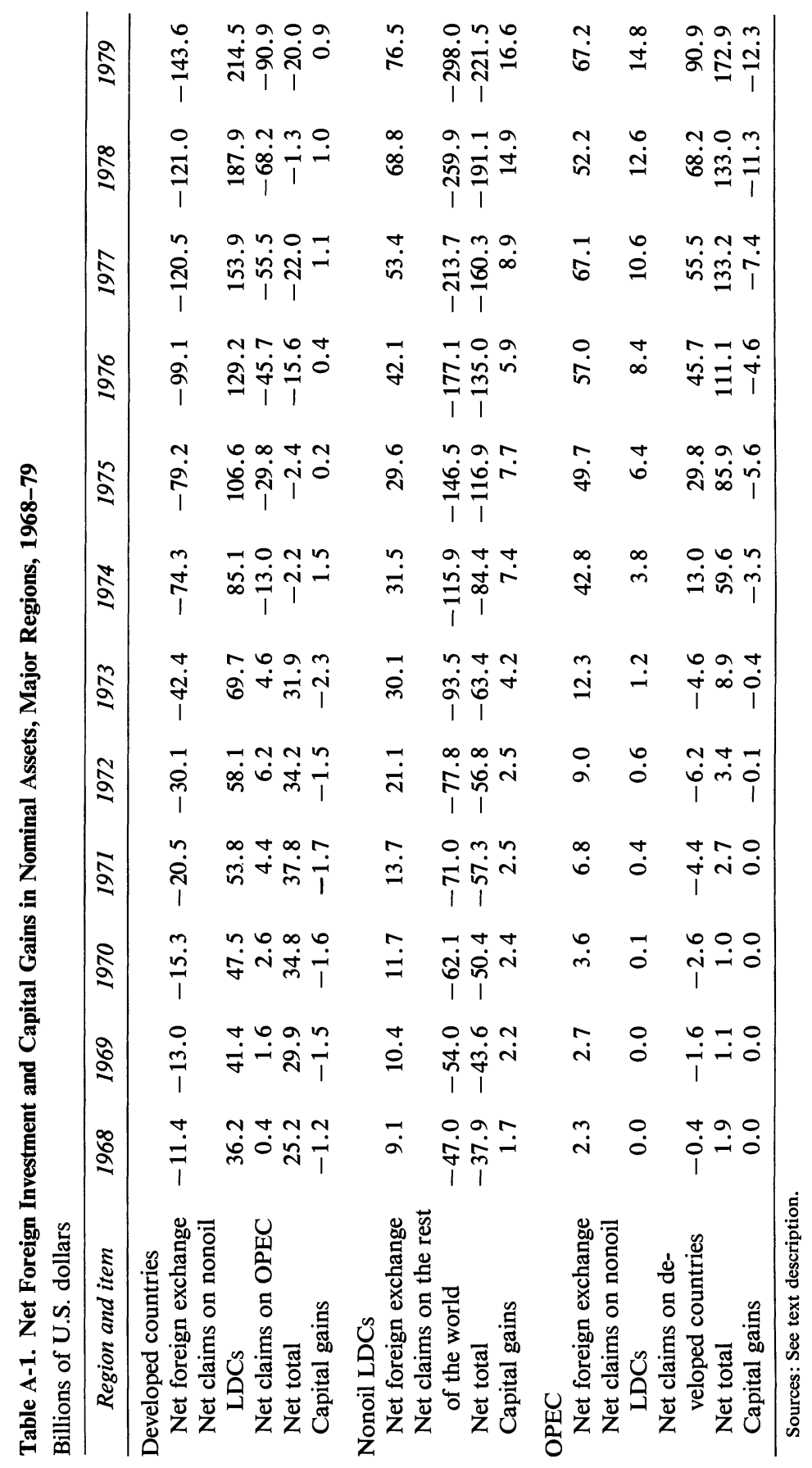




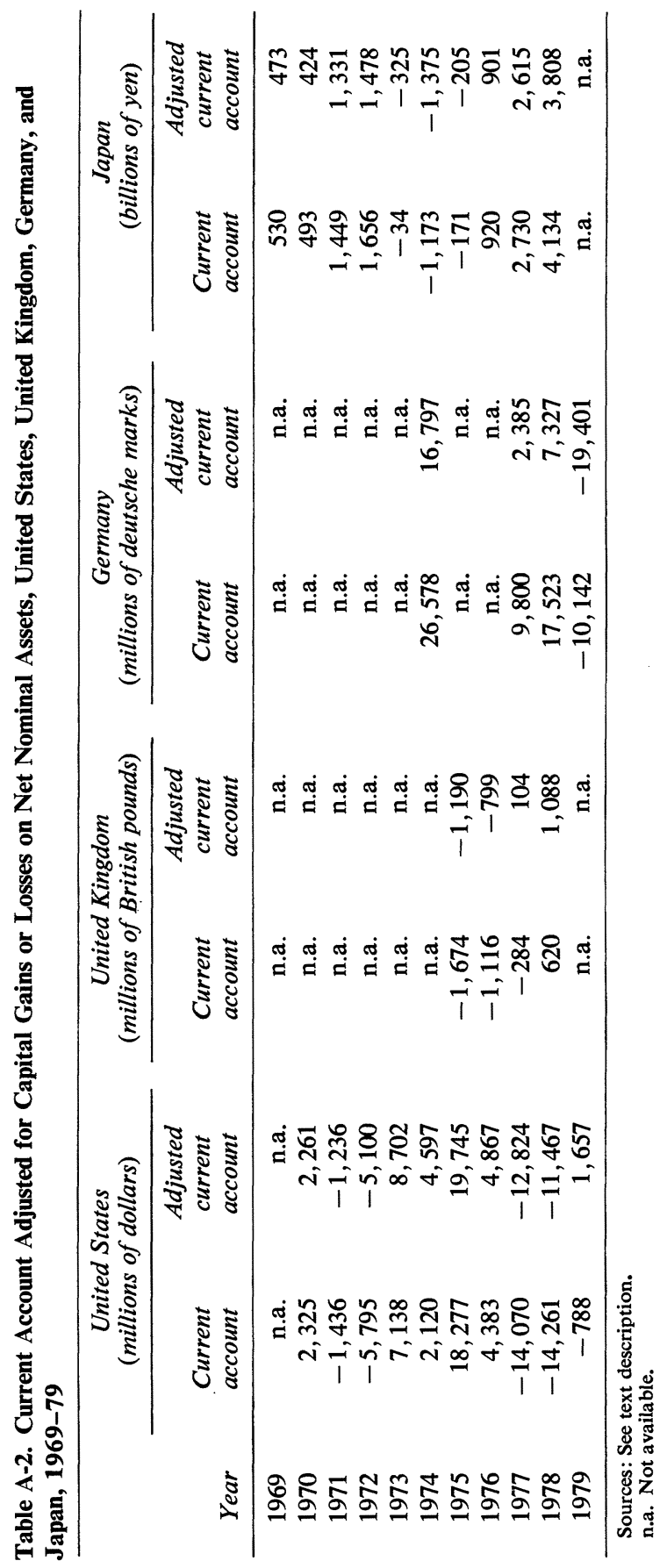


Table A-1 results from making these calculations. To determine the capital gains and losses, the U.S. inflation rate is multiplied by the net position (an average of two periods). Inflation is given as the growth of the U.S. GNP deflator from the fourth quarter of one year to that of the next.

In table A-2 the same calculations are made for four OECD economies, including the United States. Note that the United States is a net debtor in nominal assets because of the large stock of official foreign exchange liabilities of the U.S. Treasury, and thus makes capital gains each year, which raise the current account. The corrections for Germany are certainly too large because much of the German assets are mark-denominated; Germany experienced smaller capital losses than countries holding entirely dollar-denominated assets. The data for table A-2 are from sources on the individual countries: for the United Kingdom, "An Inventory of U.K. External Assets and Liabilities: end-1978," Bank of England Quarterly Bulletin, vol. 19 (June 1979), pp. 160-63; for Japan, The National Income Accounts of Japan, 1979, pp. 494-95; for Germany, "Assets and Liabilities of Banking Groups," Monthly Report of the Deutsches Bundesbank, vol. 31 (September 1979), pp. 28-34; and for the United States, Russell B. Scholl, "The International Investment Position of the United States: Developments in 1979," Survey of Current Business, vol. 60 (August 1980), pp. 52-56 and preceding issues. 


\section{Comments and Discussion}

Richard N. Cooper: Jeffrey Sachs is surely right on his fundamental proposition: current account imbalances should be allocated among countries according to their national investment opportunities relative to availability of national savings, and there is no reason to suppose these (net) opportunities are correlated with oil imports or indeed with any other single component of international transactions.

In the context of overall saving-investment analysis, countries should not take any particular view of their current account position at all. Some will draw savings from the rest of the world, others will invest in the rest of the world. Nothing is wrong with this; it is as it should be.

But suppose, wrongly, that countries do have balance-of-payments targets; or, less formally, that they have strong expectations about their payments position based on past results augmented or rationalized by some theoretical reasoning. Then suppose oil prices are raised by 300 percent, and oil is an important item in a country's balance of payments. Should that country retain its previous target (expectations), or should it revise them? And if the latter, how? On what principles?

These were the questions that some analysts and officials addressed in 1974. Their concern was that nations, in an attempt to restore their payments positions before the price increase, would engage in a fruitless and indeed mutually damaging scramble to improve those positions through deflation, import restrictions, or both. To prevent this possibility, some "burden-sharing" formula was needed. During the impact period, a rule of thumb as good as any seemed to be: each nation should adjust its expectations about its current account by the increase of its oil payments. This would only be the impact effect, and various adjustment processes could (and were assumed to) begin to work-directly in the oil market, 
as well as through the adjustment of expenditures to lowered real income. Thus these impact effects would gradually give way to a much more complex pattern of deficits in the oil-importing countries. But a key general point remained: so long as the OPEC surpluses persisted, other countries - taken together-had to have current account deficits, and this was an ineluctable fact to which the summation of targets and expectations in oil-importing countries had to accommodate.

The country-by-country pattern of these medium-term deficits can be expected to be very complex. But contrary to some views expressed in the 1970 s, there is no reason to expect that all deficits (net foreign investments) should be in developing countries, in other words, that industrial nations should eliminate their deficits. On the contrary, with new relative prices some of the best investment opportunities, from a global perspective, are likely to be in the industrial countries. With large savings now accumulating in the OPEC countries, countries that in the past have been net investors abroad might now quite properly have deficits, or, in other words, be net capital importers. To the extent that capital is readily substitutable for energy, a sharp rise in the price of energy should, ceteris paribus, lead to factor-substituting (as opposed to output-increasing) investment - to a movement along isoquants rather than to new, higher isoquants. Although this phenomenon should take place everywhere around the world, the size of the capital stock in the industrial countries that is rendered totally or partially obsolete suggests that, at least for a number of years, calls by these countries on new savings of the oilexporting countries might be substantial, and might lead to current account deficits by the industrial countries during the period of factorsubstituting investment.

Sachs' analysis and empirical results put heavy weight on swings in national investment as the principal determinant of current account positions because he finds that savings rates in practice are relatively stable. But what explains the variations in investment? In the context considered by Sachs, I suggest the following four factors may help to explain movements in national investment relative to national saving, and hence changes in current account positions.

1. The major rise in savings in OPEC countries led to an increase in world savings, which in turn lowered the real interest rate. The response of investment to lower real interest rates will presumably vary from coun- 
try to country, hence so will the change in current account arising from this factor.

2. A sharp increase in energy prices will raise sharply the marginal return to energy-reducing investment at prices and demand levels that permit full utilization. The magnitude of the resulting induced investment will presumably bear a strong positive relation to the size of each national capital stock because the complementary factors-mainly skilled labor and appropriate social structure-remain. Factor-substituting investment will occur as discussed above.

3. Movements in prices of complementary factors, especially real wages, may preclude profitable production at the previous levels. Firms find themselves noncompetitive. This effect will vary from country to country with the rigidity of real wages and, over a slightly longer period, with the substitutability of capital for labor.

4. Aggregate demand management will strongly affect the expectations of investors about their ability to sell their output in the future. The prospect of a considerable period of economic slack tolerated or induced by the authorities to fight inflation or payments deficits will be more discouraging to investors than the prospect of steady growth in real aggregate demand. Again, countries have varied considerably in this regard, with the major industrial countries generally pulling in the reins of aggregate demand in 1974, while many smaller industrial countries and developing countries tried to stay on their pre-1974 growth paths, borrowing abroad as necessary to finance the resulting imbalances in payments.

In this paper Sachs puts some weight on the first of these factors in determining national investment; in a previous paper in $B P E A, 2: 1979$ he stressed the third factor. ${ }^{1}$ All undoubtedly play some role, but I place greater emphasis on the second and especially the fourth factors as determinants of national investment, and hence (given the apparent stability of savings rates) swings in current account positions during the period under discussion.

In the final section of his paper, in which he discusses the link between exchange rates and current account imbalances, Sachs properly re-

1. Jeffrey D. Sachs, "Wages, Profits, and Macroeconomic Adjustment." 
minds us that many things influence the exchange rate and its covariance with the current account. That has long been recognized, but it is useful to be reminded of it from time to time, especially the role of exogenous disturbances. Sachs boldly sums up many of the influences on the exchange rate in his equation 14.

The task of an empirical science, however, is not so much to describe what can happen as what has happened, and why. I find Sachs' explanation of the 1970s deficient in this regard. I suggest two direct linkages between the exchange rate and the current account. One is the so-called $J$ curve: if prices change faster than quantities adjust, the current account will be influenced contemporaneously and positively. (Appreciation improves, depreciation "weakens" the current account, using conventional terminology.) This factor offers an alternative interpretation of Sachs' empirical observation of a positive correlation between movements in the exchange rate and the current account.

Over time quantity adjustment should become more important and the upward swing of the $J$ occurs. Sachs implies, correctly, that the process has to be linked to saving-investment behavior.

Another, more controversial, linkage is that the current account influences, with a lag, the exchange rate. This influence has two possible channels that are mutually supporting. The first is simply the problem of financing a current deficit under flexible exchange rates. If there is not enough autonomous capital inflow, interest rates or exchange rates must adjust to induce the capital inflow required to finance the deficit.

The second channel concerns the formation of expectations about future exchange rates. All analysts must summarize information to simplify a complex reality. Economists often make this simplification by looking at two-stage least-square estimators of coefficients in simultaneous equation systems. Others look at last week's money supply. Still others look at the patterns of averages in the stock market.

In assessing whether a country's external accounts are doing well or badly, most observers look at the balance of payments. This concept has undergone various transformations, but with the advent of flexible exchange rates no single concept makes good sense, and official statistics now proliferate. The current account-or, more correctly, the balance on goods and services-is the most comprehensible concept remaining, and people watch it. In industrial countries it appears with a lag of perhaps four months on the midpoint of the quarter covered, although fragments 
are known earlier. My guess is that this simple, comprehensible statistic influences sentiment about the exchange market-whether things are perceived to be going well or badly - and that in turn influences exchange rates. If one looks at nominal exchange rates of the major industrial countries since 1973, most movements can be explained by differential inflation rates. But the remaining changes in real exchange rates, corrected for inflation differentials, track relative current account changes quite well, with a modest lag. There are exceptions, however, as Sachs' analysis suggests there should be.

One final, brief point is that Sachs correctly reminds us that in an inflationary environment the interest component reckoned into current account payments conceals a capital transaction, because the inflation premium on interest rates is designed to preserve the real value of the capital investment. He shows that this factor is quantitatively important both in the deficits of less-developed countries and in OPEC surpluses, and it raises both by $\$ 10$ billion to $\$ 14$ billion a year. This correction to current account deficits is small comfort to the less-developed countries, however, since the inflation-corrected figures imply a faster amortization of capital than is apparent, as the effective maturity of the loans is reduced. Total debt-servicing requirements-interest plus amortizationthus remain much higher than Sachs' corrections seem to imply.

Stanley Fischer: Sachs has written a stimulating and ambitious paper that attempts to create intellectual order from the confusion of the international economy of the 1970s. The paper accomplishes two main objectives. First, it provides a useful framework for analysis of the longer-term balance of payments and the exchange rate. Second, it makes the empirical judgment that the prime force determining movements in non-OPEC current accounts and the exchange rate in the 1970s was a shift in the pattern of international investment. I take up four points: what was thought before, the theoretical apparatus, the evidence on the investment and current account hypothesis, and the current account and the exchange rate.

If a random macroeconomist had been asked, before reading this paper, whether oil was a factor that influenced the current account in the 1970s, he would almost certainly have said yes. He would have been correct. After all, the OPEC surpluses are hard to explain without oil. If asked next whether oil explains current account imbalances within the 
OECD he would have thought for a moment and mentioned Germany and Japan. Indeed, this is what Paul Volcker did in the speech from which Sachs quotes: "So long as those [OPEC] surpluses exist, other countries, taken together, will have a deficit. But oil cannot fully explain the extent of the current imbalances or how they are distributed. A handful of oil-importing countries, led by Japan, also have large and persistent surpluses. The deficits of others far exceed the impact of oil prices on their imports." 1

But what would the macroeconomist make of the current account performance of Japan and Germany? Probably the following: that the impact effect of an oil price increase is likely to worsen a country's balance of payments the more oil is imported. Then countries have to adjust, and some of them adjust better than others. Over a period longer than a year, there need not be any association between the size of oil imports and the current account for an individual country-though, given the OPEC surplus, such a relation holds for non-OPEC countries taken together. Methods of adjustment would include restrictive monetary and fiscal policy to reduce aggregate demand and probably measures to decrease the demand for imported oil-for example, allowing the domestic price of oil to rise to the world level.

Policies that concentrate on the demand for oil are inspired by the identity that the current account is equal to exports plus the service account minus imports. There is also the absorption identity, and it is necessary to show why a policy that reduces oil imports affects the difference between income and absorption. There is no infallible link. The higher price of oil might reduce the rate of return to capital and reduce investment demand. But it is quite possible that, as McKinnon and Sachs point out, policies directed to energy will have no effect on the current account. This is an important point that bears frequent repeating. Countries try to cut their oil imports not only for current account adjustment, but also io reduce their vulnerability to a cutoff of oil imports.

It does appear that more sophisticated views than the above were expressed, however. For instance, the International Monetary Fund's World Economic Outlook (May 1980) presents a careful analysis of the oil problem that contains some of the elements emphasized by Sachs. It

1. Volcker, "The Challenges of International Economic Policy," p. 2. 
argues that in a flexible-price, full-employment world an increase in the price of oil and consequent OPEC surpluses would initially

... cut real consumption and/or saving because of falling real income, and ... raise investment because of the effect of the inflow of funds from the oil exporting countries on the interest rate. The level of real domestic demand and economic activity would remain unaffected as domestic agents consumed and saved less and domestic investment rose.... In the longer run, a process of real transfer of resources from the industrial countries to the oil exporting countries would develop. . . . Part of the real transfer could, however, come from the increase in output resulting from the additional investment. This basic adjustment through investment and saving is built on three important assumptions: (i) nominal wages and prices are flexible, (ii) the investment schedule is elastic, and (iii) real wages can fall. However, none of these assumptions seems to be valid. ${ }^{2}$

The theoretical emphasis in Sachs' paper is on intertemporal maximization and the distinction between permanent and transitory disturbances. Of the three forms of the current account identity-exports minus imports, income minus absorption, and saving minus investment-Sachs' preference is for the third. Now identities have the property of being true if the data are measured correctly, so that any form is ultimately as good as any other. The reason for using one rather than another is that it shifts the emphasis in a particular way. For that reason, the exports-minusimports form of the current account is least useful. Sachs' preference for saving minus investment results from his analysis of the current account as the result of intertemporal decisions. His choice is suitable for a longerrun analysis in which full employment is assumed. Otherwise, it might be better to work with the income-minus-absorption form, which makes the analyst more conscious of income movements as potential equilibrating mechanisms. No user of the absorption form should forget that consumption and investment functions are usually derived by intertemporal optimization.

Sachs' basic model of the current account-and this is only the tip of his theoretical iceberg-is neat. Nonetheless, this particular form of the model is special. Investment is determined solely by the world interest rate, which is given. Therefore none of the domestic variables like fiscal policy or current output affect investment. Given current income, a per-

2. International Monetary Fund, World Economic Outlook (IMF, May 1980), p. 7. 
manent change in government spending entirely crowds out consumption. A transitory increase in government spending produces a current account deficit, regardless of how it is financed, since consumers internalize the government budget constraint.

The main exercise for which the model is used is to analyze the effects on the current account and the exchange rate of an increase in the price of oil. A permanent increase in the price of oil should make individuals realize that their permanent income is reduced so that income and consumption change by about the same amount, at the given world interest rate. A transitory increase in the price of oil reduces current income by more than consumption, so that the current account worsens. These answers seem about right over a period of a few years. The short-run (one-year) effect of an oil price increase on an importing country, though, is probably to create a deficit in the current account even if the price increase is permanent. This is because there is likely to be a period of reduced production as the economy adapts to the changed relative price of oil, possibly with transitional unemployment. In addition, the inelasticity of oil demand in the short run will likely increase spending or reduce saving.

The other important exercise for which the model is used deals with the effects of an increase in investment on the current account. At a fixed interest rate an increase in investment worsens the current account. Because the increased investment is treated as a rise in the demand for domestic goods, the relative price of domestic goods rises, appreciating the real exchange rate. Thus a current account deficit caused by an investment boom will be accompanied by an appreciation of the real exchange rate rather than a depreciation.

Sachs indicates briefly how to extend the model to make the world interest rate endogenous and then how to permit inflation-adjusted national interest rates to diverge from each other when capital movements are controlled. He remarks that movements in the world interest rate play an important role in equilibrating the balance of payments and undertakes some Mishkin-style regressions to show that ex post real rates have fallen in the non-OPEC world in the 1970s.

I have three comments here. First, one reason the real interest rate plays an important equilibrating role in the model is that income does not. The model should be viewed as fairly long-term. Second, the relevant 
interest rates are ex ante rates. No doubt these, too, fell in the 1970s, though the 1977 and 1978 U.S. real rates were at least positive, if one ignores taxes. The third comment is that the Sachs model deemphasizes the role of macroeconomic policy in affecting the current account or indeed the economy. Once the interest rate is free to move, or if income becomes a variable, changes in $G$ can once more have effects on the current account, and certainly government policy can affect national rates of investment. The current version of the model is useful for showing how a system with passive policy would adjust, but adjustment can and has also been helped or hindered by the government.

The most striking feature in the paper is the empirical claim that in the 1970s current account developments outside OPEC were dominated by investment shifts among countries. As Sachs is careful to emphasize, this need not have happened. National saving rates could have adjusted and investment rates could have remained stable, but instead, he argues, it went the other way. The shifts in investment are explained as resulting largely from changes in expected rates of return around the world, with the OECD countries experiencing the end of their post-World War II investment boom and the NICs taking off.

At a broad level, Sachs is surely right to emphasize the role of increased investment in the NICs and changes in investment in OECD countries as one of the major factors explaining the size and distribution of current account positions in the world economy after the oil shock. But the emphasis is surely exaggerated. Sachs disposes of two alternative hypotheses. The first is that saving caused current account shifts. The main evidence of this is provided by table 14 , in which the change in fixed investment earns a higher $\bar{R}^{2}$ in "explaining" current account changes than does the change in saving.

However, table 14 is difficult to interpret. If inventory investment were added back to investment, a regression of the change in the current account on the change in saving and the change in investment would be an identity, with an $\bar{R}^{2}$ of unity, coefficients of plus and minus one, respectively, and gratifying $t$-statistics. It is unclear how the correlation between each of the components of the definition of the current account and the current account itself helps in identifying the cause of current account changes. For instance, the data in table 9 (which were not those used in the regressions of table 14) imply that inventory investment best 
"explains" the current account. Should one conclude that current account changes after the oil shock are mainly a reflection of changed inventory accumulation?

Given the current account definition, it makes sense to ask whether saving also matters by looking at the underlying data, in tables 8 and 9 , to see how much saving and fixed investment each changed before and after 1973. It turns out that saving fluctuates more than investment when each is measured as a percentage of GNP. For instance, in table 8 the mean absolute change in the investment percentage for the NICs between 1965-73 and 1974-79 is 2.9 percentage points; for saving the mean absolute change is 3.2 percentage points. Similarly, in table 9 for the OECD countries, the mean absolute change in investment as a percentage of GNP is 2.0 percentage points, versus 2.7 points for saving. Saving does not appear to be a passive component of the current account.

A similar impression is given by examination of individual countries. In Brazil saving fell as a percentage of GNP by 2.2 percentage points between the two periods, while investment rose 0.8 point; the current account deficit increased by 1.9 points. In Mexico investment increased as a percentage of GNP by 3.1 percentage points while saving rose by 3.9 points, with the current account deficit increasing by 0.9 point, and so on.

I am not arguing that saving is the entire story or that Sachs has not performed a useful service in drawing attention to the role of investment. But it is clear that there were large movements in both saving and investment after 1973, and that an approach that emphasizes the current account as the difference between saving and investment should devote equal attention to each in analyzing changes in current account positions in the 1970s.

The second hypothesis is that cyclical movements in output have something to do with average current account performance during the 1970s. This is a difficult view to disentangle from the investment hypothesis because investment and the cycle are closely correlated. The evidence for the OECD countries, shown in table 7, weakly supports the investment hypothesis. But the weakness of the evidence is confirmed by the results of table 14: when 1974 and 1975 are omitted, investment does not significantly enter the current account equation for nonoil countries. Thus one awaits further research to confirm the relative roles of investment and the cycle in the time-series context. Sachs emphasizes that independent movements in output should produce current account surpluses given 
investment, but this view assumes the movements in output are supplyand not demand-determined.

All the regressions in this section suffer from the problem of endogeneity of the variables on the right-hand side. As Sachs notes, much more work is needed to establish the causal relation for which he is arguing. Indeed, it is not even clear whether he believes that the shifts in investment were caused by animal spirits or rather reflect shifts in rates of return on investment following changes in the prices of raw materials.

Sachs addresses the debt problem of the less-developed countries and argues strongly, as do others, for the real bills doctrine. He doubts that there is much danger of debt default because the debt has largely gone to countries that have invested. However, those are not by and large the countries about whom the world is worrying. Further, as critics of the real bills doctrine point out, what is a productive loan depends on the state of the business cycle. Loans that appear productive now will not seem productive if a cumulative process of debt default should get under way. So long as the possibility of a cumulative process is well recognized, it is likely to be avoided.

The part of the paper on exchange rates and the current account pulls together a variety of theories of the current account and argues persuasively that many movements in exchange rates are changes in real rates. The reminder that correlations between endogenous variables depend on the source of disturbances is a valuable general lesson, which will be taken to heart by all users of the Phillips curve, the Fisher equation, and so forth.

The explanation of the behavior of the dollar exchange rate and the U.S. current account during the last recovery is equally consistent with the view that trade flows react with a lag to changes in exchange rates, and that relative output levels affect the demand for imports.

The most striking argument of this paper is that shifts in investment account for the pattern of current account movements observed outside OPEC countries during the last decade - and that those shifts have relatively little to do with oil. As Sachs concludes at the end of his paper, it is certainly now a hypothesis that bears further investigation. At the same time, this hypothesis would at best characterize an empirical regularity and not an iron law of economics.

Indeed, it is a pity that a paper as interesting as this one conveys the sense of the need for a single-cause explanation of the phenomena it is 
explaining. It really is not too difficult to look at more than one cause. If we feel the need for simple explanations of current accounts in the 1970s, we can use a two-factor model: the factors are oil and nonindustrial countries.

\section{General Discussion}

Rudiger Dornbusch agreed with the emphasis Sachs had placed on the relation between saving and investment in understanding the current account and real exchange rate. However, he felt that Sachs had exaggerated the importance of investment. He suggested that the author adopt a more balanced view in which shifts in saving and investment are complementary rather than competitive explanations of the current account. Dornbusch argued that, while the recent experience of countries such as Norway is explained by shifts in investment, in other countries changes in saving are more important. For example, the recent improvement in Pakistan's current account can be attributed to the increased saving from remittances of emigrant workers in the Persian Gulf states. Dornbusch also presented data showing that changes in saving rates in Brazil are more important than movements in investment in explaining the current account during the 1970 s.

Robert Lawrence questioned the significance of investment for the United States. He noted that the time-series regression for the United States shows little evidence of a consistent relation between the rate of investment and the current account. Furthermore, Sachs' argument that the appreciation of the dollar in 1975 was due to an increased rate of U.S. investment is wrong in its timing. In fact, investment declined sharply in 1975. Similarly, the dollar declined in 1977 and 1978 when the U.S. rate of investment was relatively higher.

George Perry argued that Sachs' theoretical model paid insufficient attention to cyclical departures from trend. Whatever its relative constancy along the trend, the total saving rate is systematically correlated with departures from that trend, in part because government deficits rise with the GNP gap. This breaks the simple relation between investment and the current account. Empirically, the causal importance of different cyclical influences on the current account are hard to sort out. For example, the sign of the correlation between saving and the current account 
depends on whether changes in saving are endogenous cyclical variations or exogenous shifts. The coefficients in Sachs' equations reflect a mixture of the two effects. The performance of GNP gap in his equations may be dominated by the fact that large gaps were associated with the exogenous deterioration of the current account resulting from the OPEC oil price increases. Although Perry agreed with the importance of distinguishing between permanent and transitory shocks at a theoretical level, he observed that empirically they are difficult to distinguish. Neither economists nor economic agents can be confident about the permanence of an event, whether it is a cyclical downturn, a productivity shock, or an increase in oil price.

Lawrence reasoned that disturbances in the goods market are often the proximate determinant of the current account and real exchange rate. In the short run, a goods market disturbance, such as a decline in price competitiveness, would move the current account; eventually that move would be reversed by the long-run movement in the real exchange rate, which Sachs has conceded would result from changed competitiveness. Lawrence found that this chain of causation provided a convincing explanation for the recent behavior of the U.S. current account.

Dornbusch and George von Furstenberg questioned Sachs' investment measures for the LCDs. Dornbusch noted that both military expenditures and housing are counted as investment in the national income accounts of many LDCs but that they are of little value in servicing or repaying debt. By narrowing the definition of investment, Sachs could sharpen his tests of the importance of investment in reducing default risk and the difficulties of financing a deficit. Von Furstenberg suggested that, for some developing countries, the link between measured investment, capital imports, and energy prices is direct, but not because of the mechanisms Sachs describes. In the case of at least one country all foreign-financed expenditures related to the development of export crops and other investment projects, including expenditures on energy and fertilizer, are treated as investment. As a result, 50 percent of the additional cost of energy imports resulting from oil price increases are reported as investment.

Robin Marris questioned whether the balance of payments in the 1970s would have looked the same without the oil shock. He noted that although it was clear by the late 1960s that the growth rates of certain developing countries were accelerating while developed countries were slowing down, the decline in growth rates in developed countries in the 
1970s was greater than could be accounted for by the end of the postwar investment boom. Marris asserted this slowdown was surely due in part to OPEC. He noted that Cooper's argument that the energy price increases should have made investment relatively more attractive in the highly capitalized developed countries came up against the fact that their investment was relatively weak. Cooper responded that factors besides oil prices, including macroeconomic policy and various structural changes, may have weakened investment demand in developed countries. Franco Modigliani added that the savings created by OPEC facilitated rapid LDC development; but those savings were adequate to finance expanded investment in the developed countries as well. Instead, LDCs financed the government deficits resulting from the policy of fighting inflation with monetary rather than fiscal restrictions. Sachs added that the need to recycle OPEC savings has created a more favorable attitude toward LDC lending.

Charles Holt observed that the OPEC experience raised the awareness of industrial countries to their vulnerability to supply disruptions of all sorts of primary commodities. A natural response was to develop diversified sources of primary commodity supply, and this may have been the stimulus to direct investment in the LDCs by the industrial nations. 